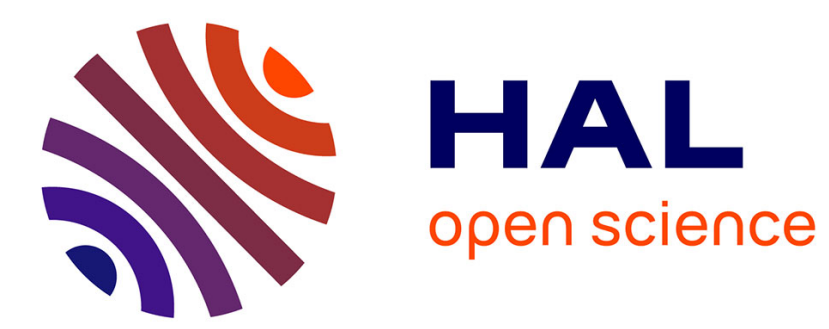

\title{
A critical review of Antarctic Conoidea (Neogastropoda)
} Yuri I Kantor, Myroslaw G Harasewych, Nicolas Puillandre

\section{To cite this version:}

Yuri I Kantor, Myroslaw G Harasewych, Nicolas Puillandre. A critical review of Antarctic Conoidea (Neogastropoda). Molluscan Research, 2016, 36 (3), pp.153-206. 10.1080/13235818.2015.1128523 . hal-02458213

\section{HAL Id: hal-02458213 \\ https://hal.science/hal-02458213}

Submitted on 28 Jan 2020

HAL is a multi-disciplinary open access archive for the deposit and dissemination of scientific research documents, whether they are published or not. The documents may come from teaching and research institutions in France or abroad, or from public or private research centers.
L'archive ouverte pluridisciplinaire HAL, est destinée au dépôt et à la diffusion de documents scientifiques de niveau recherche, publiés ou non, émanant des établissements d'enseignement et de recherche français ou étrangers, des laboratoires publics ou privés. 
A critical review of Antarctic Conoidea (Neogastropoda)

Yu. I. Kantor ${ }^{\mathrm{a} 1}$, M. G. Harasewych ${ }^{\mathrm{b}}$, N. Puillandre ${ }^{\mathrm{c}}$

${ }^{a}$ A.N.Severtzov Institute of Ecology and Evolution, Russian Academy of Sciences, Leninski prospect 33, 119071 Moscow, Russia; ${ }^{b}$ Department of Invertebrate Zoology, National Museum of Natural History, Smithsonian Institution, Washington, DC, USA; ${ }^{\mathrm{C}}$ Muséum National d'Histoire Naturelle, Departement Systematique et Evolution, Paris, France

Running head: Antarctic Conoidea

Keywords: Antarcic convergence; endemism, bathymetric distribution; new species; new name

\footnotetext{
${ }^{1}$ Corresponding author Email: kantor.yuri1956@gmail.com
} 


\section{ABSTRACT}

The Antarctic Conoidean fauna is critically reviewed based on published data and specimens in the collections of the USNM, IOAN and MNHN. Forty-two species and subspecies of the superfamily Conoidea are recorded as occurring within the Antarctic convergence (excluding the fauna of the Kerguelen Islands) and are attributed to 14 genera and seven families. These include the new taxa: Antarctospira gen. nov. (type species - Leucosyrinx badenpowelli Dell, 1990); Drilliola antarctica n. sp.; Pleurotomella (Pleutoromella) tippetti n. sp.; Pleurotomella (Anomalotomella) petiti n. sp.; Xanthodaphne pastorinoi n. sp. Aforia watsoni is introduced as a new name for Pleurotoma (Surcula) lepta Watson, 1881, non Pleurotoma lepta Edwards, 1861. Lectotype is designated for Conorbella antarctica (Strebel, 1908). New combinations include: Antarctospira badenpowelli (Dell, 1990), n. comb. (previously assigned to Leucosyrinx); Antarctospira principalis (Thiele, 1912), n. comb. (previously assigned to Typhlomangelia); Antarctospira mawsoni (Powell, 1958), n. comb. (previously assigned to Leucosyrinx); Typhlodaphne paratenoceras (Powell, 1951), n. comb. (previously assigned to Leucosyrinx); Belalora weirichi (Engl, 2008), comb. nov. (previously assigned to Oenopota); Pleurotomella (Anomalotomella) innocentia (Dell, 1990), n. comb. (previously assigned to Typhlodaphne); Pleurotomella (Anomalotomella) nipri (Numanami, 1996) (previously assigned to Typhlodaphne); Xanthodaphne raineri (Engl, 2008), n. comb. (previously assigned to Pleurotomella); Aforia hedleyi (Dell, 1990) (previously assigned to Pontiothauma). The majority of Antarctic conoidean genera and species have radulae consisting of hypodermic marginal teeth. Comparisons of species richness with other well studied faunas revealed a similar relative abundance of conoideans. The low number of conoideans in Antarctic waters is indicative of the general impoverishment of the gastropod fauna in the region. Fourteen percent ( 2 of 14 ) conoidean genera that occur in within the Antarctic convergence are endemic to Antarctic waters, as are $82 \%$ (34 of 42) of the species. Most genera and many species have very broad bathymetric ranges, some extending from bathyal to hadal depths. Greatest species diversity was at bathyal depths. 
Conoidea (=Toxoglossa) remains one of the less thoroughly studied gastropod taxa within Antarctic waters. This superfamily ranks among the most diverse clades of Neogastropoda (Bouchet et al. 2002; Bouchet et al. 2009), especially in the tropics. The classification of the superfamily Conoidea has recently been revised extensively based on a molecular phylogeny (Puillandre et al. 2011), and now includes 15 families (Bouchet et al. 2011). Thirteen of these families had previously been included in a single family, Turridae, which emerged as paraphyletic in phylogenetic analyses. These 13 families are collectively referred to here as “turrids”. Currently, about 460 conoidean genera and subgenera are recognized, 358 belonging to “turrid” families and encompassing more than 4000 named Recent species (Tucker 2004), with many hundreds of species still unnamed (Bouchet et al. 2009).

The diversity of "turrids" decreases significantly in high latitudes. Only about 40 species are known to inhabit the waters of the Arctic Ocean (Kantor and Sysoev 2006). The diversity of "turrids" in Antarctic and subantarcic waters is also very low. At present, 38 named species have been recorded from the Southern Ocean (Engl 2012), although new species remain to be discovered and named. Remarkably, the number of presently recognized Arctic and Antarctic turrids is nearly the same.

The majority of the known Antarctic “turrids”, 20 species, was described in publications based on the large Antarctic expeditions of the early $20^{\text {th }}$ century (Watson 1886; Strebel 1908; Thiele 1912; Hedley 1916). More species were added later (Powell 1951, 1958; Dell 1990; Engl 2008 a, b) based on the results of subsequent explorations of this fauna. Early authors (e.g., Watson 1886; Strebel 1908) attributed the "turrid” species inhabiting Antarctic waters to previously known broadly distributed genera, thus greatly underestimating the level of endemism of the Antarctic fauna at the genus level. This tendency was reversed by Powell (1951), who introduced several genera and one subgenus to encompass Antarctic and Magellanic “turrids”. Most of Powell's generic names are still commonly used.

Due to the scarcity of specimens, a number of Antarctic species were described based on juvenile, poorly preserved, or even fragmentary specimens, and, in many cases, on dead collected shells, posing difficulties for unambiguously identifying these taxa. Only rarely do original descriptions include such taxonomically important characters as radulae and opercula. The publications of Hain (1990) and Numanami (1996) are exceptionally informative in this regard, as they included SEM images of the radulae of several species of "turrids".

The Antarctic “turrid” fauna remains virtually unexplored from the molecular phylogenetic prospective. Only a single antarctic species, Aforia magnifica (Strebel, 1908) was represented in 
the GenBank Database (Oliverio and Modica 2010) at the time of this study. This is not surprising, due to difficulties in obtaining properly preserved material suitable for sequencing from Antarctic waters.

Prior to the present study, there have been no revisions or critical re-assesments of the systematics of Antarctic conoideans. Engl (2012) included important data on type material (including the first photographs of type specimens of many of the species) and designated several lectotypes. His publication dealt primarily with newly collected specimens obtained by German expeditions aboard the RV Polarstern. He described three new species of deep-water "turrids" based on this material, and illustrated several unnamed species. This work did not include a complete list of Antarctic Conoidea, nor did it contain synonymies. However it did apportion the included taxa according to the latest classification of Conoidea (Bouchet et al. 2011).

Over the past decade, we accumulated observations and new data on Antarctic turrids, based primarily on the very large collection of mollusks assembled by the United States Antarctic Program (USAP) expeditions and housed in the National Museum of Natural History, Smithsonian Institution. Portions of this material had been examined and sorted by R.K. Dell, and served as the basis for his important publication (Dell 1990) on the mollusks of the Ross Sea, which included descriptions of nine new species and subspecies of "turrids".

The present work is a compilation of a critical checklist of Antarctic Conoidea that summarizes the numerous, incremental advances in our knowledge of these animals, and includes updates in generic and familial allocation for many of these species. We deal only with Conoidea found within the Antarctic convergence. The Antarctic Polar Front, or Antarctic Convergence, marks the location where Antarctic surface waters moving northward sink below subantarctic waters. The Polar Front is a region of elevated current speeds and strong horizontal gradients in density, temperature, salinity, and other oceanographic properties (Moore et al. 1999) and thus forms a natural biogeographic border.

Magellanic turrids are excluded, except for two species of "Leucosyrinx" that are illustrated and referred to a new genus. The border of the Antarctic convergence is not completely resolved in certain regions, and the position of some island groups remains ambiguous. The Kerguelen islands are considered to be on or within the Antarctic Convergence in some studies (Dell 1990: 274; Orsi et al. 1995; Belkin and Gordon 1996) but north of the Antarctic Convergence in others (Engl 2012: 14; Moore et al. 1999). The conoidean fauna of the Kerguelen islands, consisting mostly of species described by Watson $(1881,1885)$ from Challenger expedition materials, is not treated here (except for species that have been recorded there, but also penetrate into the Antarctic Convergence). 
Type specimens for most conoidean taxa are not illustrated, as they were recently illustrated in color (Engl 2012).

We were able to determine COI sequences for several Antarctic conoidean taxa in cases where suitably preserved specimens were present in the collections of the USNM and MNHN. These sequences are reported in this publication and placed in phylogenetic context using appropriate outgroup taxa, including those from the temperate and tropical faunas.

\section{MATERIALS AND METHODS}

This report is based primarily on published data and on conoidean specimens sorted from the material sampled by the USAP vessels RV Eltanin (later renamed RV Islas Orcadas), RV Hero, and others, and housed in the collections of the National Museum of Natural History (USNM). Additional material, sampled by the Russian vessels RV Ob', RV Akademik Kurchatov and RV Dmitri Mendeleev housed in collections of the P.P. Shirshov Institute of Oceanology of Russian Academy of Sciences (IORAS) were made available through the courtesy of Drs. Andrey Gebruk and Elena Krylova.

Protoconch measurements and whorls number counts follow the protocols of Bouchet and Kantor (2004). Methods for counting protoconch whorls vary (often by 0.5 whorl) and are rarely specified in published accounts. Thus, the values we report may, in some cases, differ from previously published values.

Bathymetric ranges are provided based on published and original data. Bathymetric ranges of live collected specimens are also when possible.

Radulae were removed by gross dissection (dried animals were rehydrated in water), cleaned using diluted bleach $(\mathrm{NaOCl})$, coated with carbon and gold, and examined using a LEO 440 Scanning Electron Microscope (USNM) and TESCAN Vega TS5130MM (A.N.Severtzov institute of Ecology and Evolution).

Specimens for molecular analyses (Table 1 ) were preserved in $95^{\circ}$ alcohol. For COI sequences with voucher material in the collections of USNM, DNA was extracted from $20 \mathrm{mg}$ snippets of foot tissue, amplified and sequenced following protocols published in Harasewych et $a l$. (2011). For the remaining sequences, a piece of foot was clipped and DNA was extracted using the 6100 Nucleic Acid Prepstation system (Applied Biosystems, St Aubin, France). A fragment of 658bp of the COI (Cytochrome Oxidase subunit I) gene was amplified following the protocole described in Kantor et al. (2012). The PCR products were purified and sequenced by 
the Eurofins sequencing facility. Both directions were sequenced to confirm accuracy of each sequence. Sequences were aligned manually.

\section{$<$ Table 1 ABOUT HERE>}

To identify appropriate outgroups for the Antarctic species sequenced, we initially performed a quick analysis (Neighbor-Joining with MEGA 5) on a single dataset that included newly obtained COI sequences of Antarctic turrids and COI sequences of conoideans available in GenBank and in our own MNHN database (results not shown). Species of Antarctic turrids clustered into three groups. Three Bayesian analyses were then performed, one for each group of Antarctic turrids combined with COI sequences of turrids identified as being potential sister groups by the Neighbor-joining analysis.

Phylogenetic analyses were performed using MrBayes 3.2.2 (Huelsenbeck et al. 2001) on XSEDE implemented on the Cipres Science Gateway (http://www.phylo.org/portal2/). The analysis consisting of eight Markov chains each of 1,000,000 generations with a sampling frequency of one tree per thousand generations; the number of swaps was set to 5 and the chain temperature at 0.02 . Parameters of the substitution model were estimated during the analysis (6 substitution categories, a gamma-distributed rate variation across sites approximated in four discrete categories and a proportion of invariable sites). A different model of substitution was applied for each codon position of the COI gene. Convergence of each analysis was evaluated using Tracer 1.4.1 (Rambaut and Drummond 2007) to check that ESS values were all greater than 200 (default burning).

Families are arranged according to the phylogeny of Puillandre et al. (2011), genera alphabetically within each family. Species within a genus are treated chronologically, beginning with the type species.

Abbreviations:

AL, aperture length; AW, aperture width; BWL, last whorl length; lv, live collected specimen; sh, shell; SL, shell length; SW, shell width.

Institutional abbreviations:

AMS - Australian Museum, Sydney, Australia;

IORAS - P.P. Shirshov Institute of Oceanology, Russian Academy of Sciences, Moscow, Russia;

MNCN - Museo Nacional de Ciencias Naturales; Madrid, Spain;

MNHN - Muséum National d'Histoire Naturelle, Paris, France;

NHMUK - The Natural History Museum, London, United Kingdom; 
NIWA - New Zealand Oceanographic Institute, Wellington, New Zealand;

NMNZ - Museum of New Zealand Te Papa Tongarewa, Wellington, New Zealand;

NSMT - National Science Museum, Japan;

SAM - South Australian Museum, Adelaide, Australia;

USNM - National Museum of Natural History, Smithsonian Institution, Washington DC, USA;

ZIN - Zoological Institution, Russian Academy of Sciences, St.-Petersburg, Russian Federation;

ZMB - Museum für Naturkunde, Berlin, Germany;

ZSM - Zoologische Staatssammlung, München, Germany

\section{SYSTEMATICS}

\section{Class GASTROPODA Cuvier, 1797 \\ Order NEOGASTROPODA Wenz, 1938 \\ Superfamily CONOIDEA Fleming, 1822}

\section{Family BORSONIIDAE Bellardi, 1875}

\section{Genus Antarctospira n. gen.}

Type species (original designation): Leucosyrinx badenpowelli Dell, 1990.

Diagnosis: Shell medium sized to large, attaining $54.4 \mathrm{~mm}$, fusiform, with spire of medium hight and short, attenuated siphonal canal. Whorl profile strongly angulated at shoulder. Protoconch paucispiral, bulbous. Teleoconch whorls weakly convex, subsutural ramp shallow. concave. Anal sinus nearly symmetrical, deepest near midpoint of subsutural ramp. Axial sculpture of weak to moderately pronounced, closely spaced ribs, more strongly pronounced on and below the shoulder. Spiral sculpture of strongly to weakly pronounced, distinct, narrow, flat cords, with interspaces narrower than cords. Aperture high, narrow to broadly oval.

Operculum present, but not examined.

Radula of hypodermic, straight marginal teeth, each with a swollen base, narrow and long apical opening of tooth canal, without barbs, blade very reduced, small.

Remarks: The type species of this new genus, Leucosyrinx badenpowelli, was originally described within Leucosyrinx Dall, 1889, a genus presently classified in Pseudomelatomidae (Bouchet et al. 2012). This species cannot be included in Leucosyrinx because of its different 
radula and lack of an odontophore. The radular morphology of this species is more compatible with species of Borsoniidae. As there are no known borsoniid genera that can accommodate "Leucosyrinx" badenpowelli, a new genus is proposed here. Antarctospira differs from Typhlodaphne in having a distinctly angulated whorl profile, as well as slightly different hypodermic marginal teeth that lack barbs or blade. Although an operculum is present in the type species, it was not examined, since it was lost in the only preserved specimen (see below).

We attribute five species to Antarctospira, despite having information on radular morphology for only two of these species. Three species, the type species, Typhlomangelia? principalis Thiele, 1912, and Leucosyrinx mawsoni Powell, 1958 are from Antarctic waters, while two species, Leucosyrinx paragenota Powell, 1951 (type locality - Burdwood Bank, south

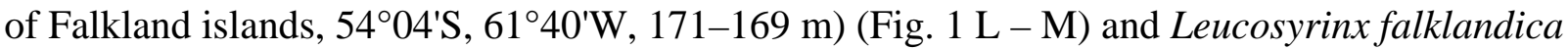
Powell, 1951 (type locality - north of Falkland islands, 53' $16^{\prime} \mathrm{S}, 6^{\circ} 12^{\prime} \mathrm{W}, 336-342 \mathrm{~m}$ ) (Fig. $1 \mathrm{~N}$ - O) are subantarctic. As the two subantarctic species have not been illustrated since their description, photographs of their holotypes are included. Both are similar to Antarctospira badenpowelli, but differ in having a thicker, more heavily sculpted shell and a smaller protoconch.

Distribution: Antarctic and subantarctic waters.

Etymology: the name reflects the Antarctic distribution of the genus, while spira - is commonly used root in the names of turrid genera.

\section{Antarctospira badenpowelli (Dell, 1990), n. comb.}

(Fig. $1 \mathrm{~A}-\mathrm{F}$ )

Leucosyrinx badenpowelli Dell 1990: 224, 227, figs 393, 410; Engl 2012: 184, pl. 75, fig. 2a-c.

Type locality: RV Burton Island, Deep Freeze III, st. 3, Victoria Land, McMurdo Sound, east of Cape Hallett, $72^{\circ} 08$ 'S, $172^{\circ} 10^{\prime} \mathrm{E}, 433 \mathrm{~m}$.

Type material: Holotype USNM 613118, SL 19.9 mm (Fig. 1 A-B); paratypes USNM 860180, SL 21.5 mm (Fig. 1 C); NMNZ M.249869.

Material examined: Holotype; Paratype 1, South Shetland islands, RV Burton Island, 726'S, 172²12'E, 433 m (USNM 860180, 1 lv); Ross Sea, Victoria Land, Cape Adare, RV Eltanin, cruise 27, sta. 1870, 71¹8'S, 171³0'W, 659-714 m (USNM 896660, 4 lv); Ross Sea, Victoria Land, Cape Adare, RV Eltanin, cruise 27, sta. 1870, $71^{\circ} 18^{\prime} \mathrm{S}, 171^{\circ} 30^{\prime} \mathrm{W}, 659-714 \mathrm{~m}$ (USNM 896845, 1 lv,).

\section{<FIGURE 1 ABOUT HERE $>$}


Morphology: Protoconch 1.5 whorls, large, bulbous, smooth, demarcated from the teleoconch by a distinct varix. Diameter $\sim 2.3 \mathrm{~mm}$, height $2.1 \mathrm{~mm}$. Presence of operculum inferred based on clear presence of an opercular disk on the foot of a dried paratype. Rehydrated animal was female. Eyes present, proboscis very short and wide, strongly contracted.

Radula (Fig. 1 D-F) of hypodermic marginal teeth with moderately long ligament and vestigial subradular membrane, maintaining radular orientation in the radular sac. Teeth straight, with medium sized rounded swollen base and lateral basal opening of tooth canal. Apical opening lateral, without barbs but with small blade. Tooth length $330 \mu \mathrm{m}(2.44 \%$ of AL).

Distribution: Ross Sea, live 237-714 m (Dell 1990, collections of USNM).

\section{Antarctospira principalis (Thiele, 1912), n. comb.}

(Fig. $1 \mathrm{G}-\mathrm{H}$ )

Typhlomangelia? principalis Thiele 1912: 215-216, pl. 14, fig. 6-7, textfig. 2 (radula); Aldea et al. 2008: 356; Troncoso and Aldea 2008: 1261; Engl 2012: 178-179, pl. 72, fig. 7.

Type locality: Gauss-Station, Davis Sea, 6602'09"S, 89³8'E, 385 m.

Type material: Lectotype: ZMB Moll 62984a, designated by Engl (2012), SL 13.7 mm (Fig. $1 \mathrm{G}-\mathrm{H}$ ). Paralectotypes ZMB 62984, two very small juveniles and fragments of at least three shells (largest $29 \mathrm{~mm}$ in length).

Material examined: type material.

Morphology: Protoconch large, high mamillate, of $\sim 2$ whorls, eroded in lectotype, diameter and height $\sim 2.5 \mathrm{~mm}$. Protoconch of juvenile paralectotype (Fig. 1 I) covered by thin but distinct spiral striae. Operculum unknown. Thiele (1912) illustrated the radula of the paralectotype (Fig. $1 \mathrm{~J}$ ), showing it to consist of hypodermic marginal teeth with a large base and likely one inconspicuous barb on the tip. Length around $200 \mu \mathrm{m}(5.8 \%$ of AL).

Remarks: This species was originally described in the genus Typhlomangelia G.O.Sars, 1878, and referred to it by subsequent authors. Typhlomangelia was first established as a subgenus of Pleurotoma to contain a single North Atlantic species, Pleurotoma nivale Lovén, 1846. Later, Watson (1881) described several additional species from Japan, the West Indies, and subantarctic waters, attributing them to Typhlomangelia without discussion. Sysoev (1996a) described two additional species from the Indian Ocean. As currently understood, Typhlomangelia contains 13 species (Gofas 2015), most assigned to the genus on the basis of conchological similarities. The shell of $T$. principalis differs significantly from the type species, which is high-spired and has widely spaced axial ribs that form pronounced knobs along the 
shoulder. Thiele (1912) based his assignment of principalis to Typhlomangelia on the general similarity of its radula to that of the type species T. nivale (radula illustrated by Sars 1878, pl. 9, fig. 106). However, T. principalis more closely resembles Antarctospira badenpowelli in shell shape and radular morphology. It differs in having a slightly coarser sculpture, fewer axial folds, and a more angulated profile of the upper teleoconch whorls than A. badenpowelli. The radular teeth of A. principalis (Fig. $1 \mathrm{~J}$ ) differ from those of A. badenpowelli in their proportionally larger size (5.8\% AL vs. 2.4\% AL), but this may be due to the small size (5 mm) of the specimen from which Thiele obtained the radula. The lectotype and paralectotype of $A$. principalis are both very young specimens. However, shell fragments in the original type series (Thiele did not designate a type, therefore all the specimens were syntypes prior to Engl's (2012) lectotype designation) were estimated to have come from specimens $38 \mathrm{~mm}$ (Engl 2012: 179) to $40 \mathrm{~mm}$ (Thiele 1912: 216) in size. There have been several reports of this species in the literature (eg. Aldea et al. 2008; Troncoso \& Aldea 2008), but the lack of illustrations makes these reports difficult to evaluate.

Distribution: Davis Sea, Bellingshausen Sea, 310-1400 m (Aldea et al. 2008, unconfirmed record).

\section{Antarctospira mawsoni (Powell, 1958), n. comb.}

(Fig. $1 \mathrm{~K}$ )

Leucosyrinx mawsoni Powell 1958: 201-202, pl. 3, fig. 4; Engl 2012: 184, pl. 75, fig. 4 (holotype).

Typhlomangelia? principalis. - Egorova 1982: 50, figs 64, 209, 210 (not of Thiele 1912).

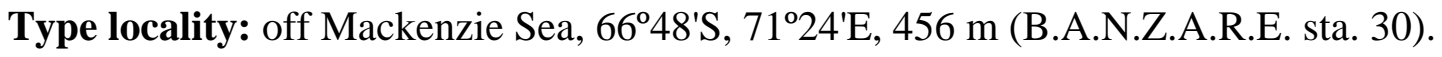

Type material: Holotype: SAM (D 15509), SL 37.75 mm.

Material examined: no material available.

Morphology: Protoconch unknown. The operculum is small, oval with a terminal nucleus (Egorova 1982: fig. 210, as Typhlomangelia? principalis). Radula (Egorova 1982: fig. 64) of nearly straight hypodermic teeth without barbs or blade and with large swollen base and large basal opening.

Remarks: The species description was based on a dead-collected, worn holotype and an additional small shell, both studied by Powell. Neither animal nor radula are known.

Egorova (1982) described and illustrated by a line drawing a specimen from the Davis Sea that she identified as Typhlomangelia? principalis. Her drawing is similar to the holotype of 
Antarctospira mawsoni. She noted that the species attains $54.4 \mathrm{~mm}$ in length. The radula is similar to that of $A$. badenpowellii and A. principalis.

Antarctospira mawsoni may prove to be a junior synonym of A. principalis.

Distribution: from Enderby Land to Mackenzie Sea [now Mackenzie Bay, western Avery Ice Shelf, MacRobertson Land], 193-456 m (Powell 1958).

\section{Genus Belaturricula Powell, 1951}

Belaturricula Powell 1951: 170. Type species (original designation): Bela turrita Strebel, 1908; Recent, Antarctica.

Diagnosis: Shell large, attaining 100 mm, fusiform, with high spire, narrowly ovate last whorl and short, spout-like siphonal canal. Protoconch paucispiral, large, smooth. Teleoconch whorls weakly convex, subsutural ramp shallow concave, or absent. Anal sinus subsutural, very shallow. Axial sculpture limited to growth lines and, in some species, indistinct, irreguarly spaced axial ribs. Spiral sculpture of narrow to moderately wide, dense spiral cords covering entire shell. Aperture of medium hight, narrow, oval.

Operculum present, small, with terminal nucleus.

Radula of slightly curved, hypodermic marginal teeth with small rounded bases and two distinct, medium sized apical barbs.

Remarks: As the radula of Belaturricula was unknown at the time, Powell (1966: 34) assigned this genus to the subfamily Turriculinae (=Cochlespirinae), which are known to possess duplex marginal teeth (Bouchet et al. 2011). Dell (1990: figs 430, 431) subsequently illustrated the radulae of Belaturricula turrita multispiralis and B. antarctica (= B. gaini), showing them to consist of hypodermic marginal teeth with distal barbs, yet retained Powell's subfamilial attribution. Later, Belaturricula was attributed to Mangeliinae (Sysoev in Taylor et al. 1993), to Conidae (Clathurellinae) (Kantor and Harasewych 1999), and provisionally to Borsoniidae (Bouchet et al. 2011).

The newly acquired COI sequences for the three species of Antarctic Belaturricula indicate that these taxa form a monophyletic clade that is sister group to Borsonia sp. and more distantly related to Bathytoma spp. (Fig. 2), a placement that is congruent with anatomical data.

\section{$<$ FIGURE 2 ABOUT HERE $>$}


Powell (1969: 362) provisionally reaffirmed earlier attributions (Powell 1951: 170; 1966: 34) of the deep-water Philippine species Pleurotoma (Surcula) dissimilis Watson, 1886 to Bellaturricula based solely on shell morphology, as neither protoconch nor radula were known for this species. No new data on the species were aqcquired since.

Belaturricula is quite similar to the genus Abyssothauma Sysoev, 1996, which includes a single species Moniliopsis psilarosis Barnard, 1963 from deep water (3155-3255 m), off Cape Point, South Africa. Sysoev (1996b: 24) noted the resemblance of the new genus to Belaturricula and additionaly to Ponthiothauma ergata, now transferred to Belaturricula. The differences include the presence of more pronounced axial ribs on upper whorls in A. psilarosis and absence of barbs on the radular teeth (Barnard 1963: 422).

Distribution: Off South Africa, Philippines, and Antarctica, in 70-1646 m. Of the four recognized species, one ranges from South Africa to the Philippines [B. dissimilis (Watson, 1881)], the remaining three, including one subspecies, are limited to the waters off Antarctica.

\section{Belaturricula turrita turrita (Strebel, 1908)}

(Fig. 3 A-C)

Bela turrita Strebel 1908: 18, pl. 3, fig. 32 a-c.

Belaturricula turrita. - Powell 1951: 170; Carcelles 1953; Powell 1966: pl. 8, fig. 5; Powell 1969: 362 [23-448], pl. 274, fig. 1; Zelaya 2005: 128, fig. 51; Dell 1990: 228, fig. 399; Castellanos and Landoni 1993: 4, pl. 3, fig. 20.

Type locality: Shag Rock Bank, 5334'S, 4323'W, 160 m, Swedischen SüdpolarExpedition, sta. 17.

Type material: Holotype: SMNH Type-1340 (Fig. 3 A-C, illustrated for the first time), SL $60.0 \mathrm{~mm}$. The label identifies the specimen as a syntype. However, there is no evidence that other specimens were ever present in the type series. Strebel (1908: 18) refered only to a single specimen that exactly matches the present specimen in size. We therefore treat this specimen as the holotype.

Material examined: South Georgia Island, RV Islas Orcadas, cruise 575, sta. 16, 53³8'24"S, 38¹'12"W, 130-133 m (USNM 894455, 5 sh); South Georgia Island, RV Islas

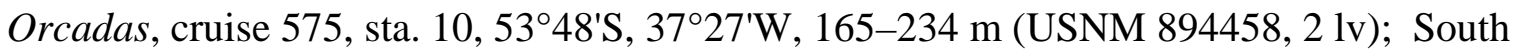
Georgia Island, RV Islas Orcadas, cruise 575, sta. 9, 5343'12"S, 37³0'36"W, 271-313 m (USNM 894473, 1 sh); South Georgia Island, RV Islas Orcadas, cruise 575, sta. 13, 5344'24"S, 3759'24"W, 128-137 m, (USNM 894481, 1 sh); South Georgia Island, RV Professor Siedlecki,

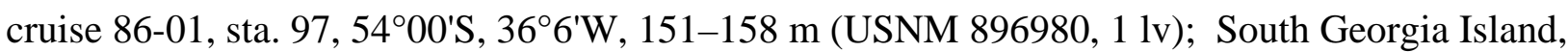


RV Professor Siedlecki, cruise 86-01, sta. 97, 53³6'S, 386'W, 159-169 m (USNM 896983, 1

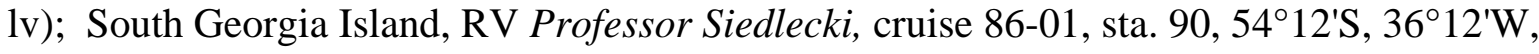
242-262 m (USNM 896996, 3 lv); South Georgia Island, RV Professor Siedlecki, cruise 86-01, sta. 98, 54º0'S, 36² $18^{\prime} \mathrm{W}, 166-197$ m (USNM 897401, 2 lv); South Georgia Island, RV Professor Siedlecki, cruise 86-01, sta. 44, 54³0'S, 37²4'W, 152-162 m (USNM 897404, 1 lv); South Georgia Island, RV Professor Siedlecki, cruise 86-01, sta. 44, 5454'S, 35²4' W, 127-140 m (USNM 897413, 2 lv); South Georgia Island, RV Professor Siedlecki, cruise 86-01, sta. 60, 552'ㄴ, 3524'W, 207-218 m (USNM 897414, 2 lv); South Georgia Island, RV Professor Siedlecki, cruise 86-01, sta. 67, 5500'S, 35³0'W, 117-122 m (USNM 897428, 1 lv); South Georgia Island, RV Professor Siedlecki, cruise 86-01, sta. 107, 53²'S, 3700'W, 226-249 m (USNM 897440, 3 lv); South Georgia Island, RV Professor Siedlecki, cruise 86-01, sta. 119, 53ํ5'S, 38²4'W, 162-168 m (USNM 897447, 2 lv); South Georgia Island, RV Professor Siedlecki, cruise 86-01, sta. 93, 5400'S, 35³6'W, 170-194 m (USNM 897454, 2 lv); South Georgia Island, RV Professor Siedlecki, cruise 86-01, sta. 111, 5354'S, 37³0'W, 104-112 m (USNM 897460, 4 lv); South Georgia Island, RV Professor Siedlecki, cruise 86-01, sta. 124,

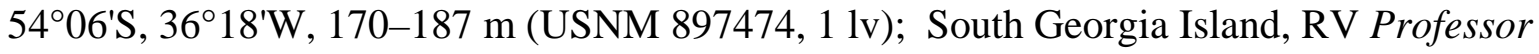
Siedlecki, cruise 86-01, sta. 17, 54º0'S, 39²12'W, 328-412 m (USNM 897500, 1 lv); South Georgia Island, RV Professor Siedlecki, cruise 86-01, sta. 23, 5406'S, 3842'W, 197-207 m (USNM 897501, 2 lv); South Georgia Island, RV Professor Siedlecki, cruise 86-01, sta. 35, 54ㄴ2'S, 38²4'W, 178-185 m (USNM 897512, 2 lv); South Georgia Island, RV Professor Siedlecki, cruise 86-01, sta. 105, 5342'S, 36²8'W, 161-192 m USNM 897516, (7 lv); South Georgia Island, RV Professor Siedlecki, cruise 86-01, sta. 105, 54º6'S, 38²4'W, 197-207 m (USNM 897522, 4 lv); South Georgia Island, RV Professor Siedlecki, cruise 86-01, sta. 37, 54ํ18'S, 37054'W, 158-194 m (USNM 897535, 1 lv); South Georgia Island, RV Professor Siedlecki, cruise 86-01, sta. 84, 54³0'S, 35³6'W, 231-249 m (3 USNM 897541, lv); South Georgia Island, RV Professor Siedlecki, cruise 86-01, sta. 57, 55²06'S, 3554'W, 152-178 m (USNM 897547, 1 lv); South Georgia Island, RV Professor Siedlecki, cruise 86-01, sta. 87, 54ํํㅇ' 35³6'W, 238-247 m (USNM 897559, 2 lv); South Georgia Island, RV Professor Siedlecki, cruise 86-01, sta. 21, 5354'S, 38³6'W, 193-195 m (USNM 897580, 1 lv,).

Morphology: Protoconch bulbous, smooth, paucispiral; operculum and radula unknown.

Remarks: The nominotypical subspecies appears to be endemic to South Georgia and Shag Rocks. It differs from the more widely ranging subspecies B. turrita multispiralis (see below) in having fewer, weaker spiral cords.

Distribution: South Georgia and Shag Rocks, 97-412 m, live 104-412 m (Dell 1990; USNM material). 
<FIGURE 3 ABOUT HERE>

\section{Belaturricula turrita multispiralis Dell, 1990}

(Fig. 3 D-E)

Belaturricula turrita multispiralis Dell 1990: 228, figs 400, 430 (radula); Engl 2012: 177-178, pl. 72, figs 2a-2b.

Type locality: Bransfield Strait, Antarctic Peninsula, 63ำ14'S, 58²45'W, 73 m, RV Eltanin st. 436.

Type material: Holotype: USNM 860139 (Fig. 3 D), SL 75.6 mm, paratypes USNM 860140 (type locality), USNM 860178, NMNZ (M.256618, type locality).

Material examined: type material; off South Shetland islands, RV Eltanin, cruise 6, sta. 445, 6200'S, 5906'W, 101 m (USNM 860178, 1 sh, paratype); Bransfield Strait, Antarctic Peninsula, RV Eltanin, cruise 6, sta. 436, 6314'S, 5845'W, 73 m (USNM 870307, 1 lv); Antarctic Peninsula, Argentine islands, Penola Strait, RV Hero, cruise 824, sta. 13-1, 65¹3'48"S, 64²12'W, 310-360 m (USNM 894477, 2 sh); N of tip of Antarctic Peninsula, K. Halanych, sta. $21,63^{\circ} 09^{\prime} \mathrm{S}, 5^{\circ} 07^{\prime} 12^{\prime \prime} \mathrm{W}, 146-192 \mathrm{~m}$ (USNM 1099807, $1 \mathrm{lv}$ ); $\mathrm{N}$ of tip of Antarctic Peninsula, K. Halanych, sta. 21, 6309'S, 5707'12"W, 146-192 m (USNM 1121893, 1

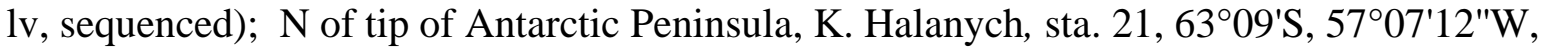
146-192 m (USNM 1121960, 1 lv); N of tip of Antarctic Peninsula, K. Halanych, sta. 21, 6309'S, 5707'12"W, 146-192 m (USNM 1122047, 1 lv, sequenced).

Morphology: The radula was first illustrated by Dell (1990: fig. 430) as a schematic line drawing of a hypodermic, long marginal tooth with a rounded base and single barb near the tip.

Remarks: Partial sequences of the COI gene were determined for two specimens (USNM 1121893 and 1122047). The sequences were nearly identical, differing by a single base pair (of $658 \mathrm{bp}$ ), and clearly distinguished them from the other sequenced species of Belaturricula $-B$. gaini and B. ergata (Fig. 2).

Distribution: Antarctic Peninsula, Scotia Sea, South Shetland islands, 73-360 m, live 73192 m (Dell 1990; USNM material).

\section{Belaturricula gaini (Lamy, 1910)}

(Fig. 3 F-G)

Sipho gaini Lamy 1910: 319; 1911: 7, pl. 1, figs 7-8.

? Chlanidota gaini. - Powell 1951: 142. 
Belaturricula antarctica Dell 1990: 228-229, figs 401, 431.

Belaturricula gaini. - Kantor and Harasewych 1999: 430-432; Engl 2012: 177, pl. 72, fig. 3.

Type localities: Sipho gaini - off King George Island, South Shetland islands, 420 m; Belaturricula antarctica - off South Shetland islands, 6256.9'S, 6050.1'W, 154 m, RV Hero, sta. 465.

Type material: Holotype: Sipho gaini - MNHN 27405, SL 32.9 mm; Belaturricula antarctica - USNM 860141, SL 67.6 mm (Fig. 3F).

Material examined: Holotypes of Sipho gaini and Belaturricula antarctica; Antarctic Ocean, RV Eltanin, cruise 6, sta. 437, 6248'S, 60³6'W, 267-311 m (USNM 860142, 1 sh, paratype of Belaturricula antarctica); Antarctic Peninsula, NE of Joinville Island, RV Eltanin, cruise 12, sta. 1003, 6240'48"S, 54²3'12"W, 210-220 m (USNM 860143, 1 sh, paratype of Belaturricula antarctica); Antarctic Ocean, Scotia Sea, RV Eltanin, cruise 12, sta. 1079, 612' S, 415' W, 593-598 m (USNM 860144, 1 lv, paratype of Belaturricula antarctica); Palmer Peninsula, W of Renaud Island, RV Polar Duke, 65³6'S, 67¹8'W, 200 m (USNM 846187, 1 sh); Palmer Peninsula, W of Renaud Island, RV Polar Duke, 65³6'S, 67²18'W, 200 m (USNM 846188, 1 sh); Palmer Peninsula, E of Hugo Island, RV Polar Duke, 6506'S, 655'W, 150 m (USNM 846189, 1 sh); Scotia Ridge, SE of South Orkney islands, RV Eltanin, cruise 12, sta. $1079,61^{\circ} 24^{\prime} \mathrm{S}, 41^{\circ} 54$ 'W, 593-598 m (USNM 870624, 1 sh); Scotia Sea, RV Eltanin, cruise 12, sta. 1084, 60²4'S, 4654'W, 298-403 m (USNM 870644, 1 sh); Ross Sea,Victoria Land, South of Coulman Island, RV Eltanin, cruise 27, sta. 1885, 74³0'S, 170¹2'E, 311-328 m (USNM 870946, 1 sh); Antarctic Peninsula, Palmer Archipelago, Anvers Island, RV Hero, cruise 812, sta. 18-1, 64²7'24"S, 64'7'12"W, 68-85 m (USNM 881527, 1 lv); Antarctic Peninsula, Graham Land, Joinville Island, RV Eltanin, cruise 12, sta. 1002, 62 ${ }^{\circ} 42^{\prime} \mathrm{S}$, 544'ㄹ, 265 m (USNM 881974, 1 lv); South Shetland islands, Bransfield Strait, S of Low

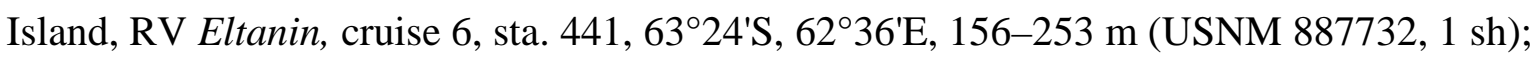
Ross Sea, RV Hero, cruise 721, sta. 941, 64²4'48"S, 64²'12"E, 90 m (USNM 890948, 1 sh); Ross Sea, Victoria Land, Cape Adare, RV Eltanin, cruise 27, sta. 1870, 71'18'S, 171³0'E, 659714 m (USNM 896742, 1 lv); South Georgia Island, RV Professor Siedlecki, cruise 86-01, sta. 72, 545ㄴ'S, 35³6'W, 84-103 m (USNM 897565, 1 lv); Antarctic Peninsula, Bransfield Strait, RV Hero, cruise 833, sta. 21-1, 63²3'24"S, 570'36"W, 276-280 m (USNM 897602, 1 lv); South Shetland islands, Low Island, RV Hero, cruise 833, sta. 22-4, 6318'36"S, 6152'48"W, 228-264 m (USNM 897631, 3 lv); South Shetland islands, Elephant Island, RV Polarstern,

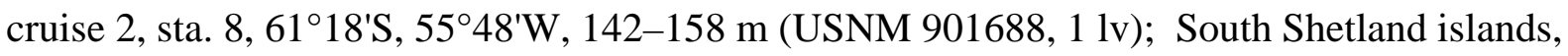
Elephant Island, RV Polarstern, cruise 2, sta. 28, 61ํ'ㄴ, 5554'W, 214-219 m (USNM 901689, 


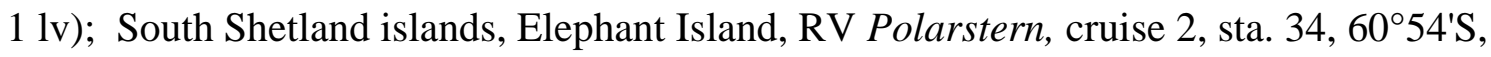
552'W, 281-302 m (USNM 901690, 1 lv); Antarctic Peninsula, Palmer Archipelago, Anvers Island, RV Hero, cruise 731, sta. 1802, 64²47'24"S, 64²'36'W, 107 m (USNM 901858, 1 lv); Antarctic Peninsula, Brabant Island, K. Halanych, sta. 29 (A, B), 648'24"S, 62 45'36'W, 156 m (USNM 1121911, 1 lv, sequenced); Antarctic Peninsula, off Trinity Island, K. Halanych, sta. 12, 6340'8.76"S, 61¹0'3"W, 126 m (USNM 1121929, 1 lv sequenced).

Morphology: Protoconch large (2.4-2.8 mm diameter), rounded, 1/3 whorls, eroded in most specimens. Operculum (Kantor and Harasewych 1999: fig. 1d) small (<1/4 aperture length), unguiculate, its nucleus strongly deflected to the right. Radula (Kantor and Harasewych 1999: figs 3 a-e) of long, slender, hypodermic marginal teeth with small rounded bases and two distinct apical barbs, one larger than the other. Distal opening of the tooth canal lateral. Tooth length $\sim 810 \mu \mathrm{m}$ (3.24\% of AL). A well-developed ligament maintains the regular arrangement of teeth within the radular sac.

Remarks: This species was originally described in the genus Sipho and referred to the family Buccinulidae until anatomical studies (Kantor and Harasewych 1999) showed it to be a member of the genus Belaturricula and a senior synonym of Belaturricula antarctica.

Distribution: Antarctic Peninsula, islands of the Scotia Arc, Weddell, and Ross seas, 68714 m, live 68-714 m (Dell 1990; Engl 2012; USNM material).

\section{Belaturricula ergata (Hedley, 1916)}

(Fig. $3 \mathrm{H}-\mathrm{L}$ )

Pontiothauma ergata Hedley 1916: 55, pl. 8, figs 85-87; Powell 1958, p. 204, pl. 3, fig. 7, text figs C. 1-4; Powell 1960: 160 (distribution record); Egorova 1982: 50, figs 63a, b, 204, 205; Hain 1990: 72, pl. 8, figs 6a-d, pl. 27, fig. 2; Dell 1990: figs 418-419 (holotype); Numanami 1996: 224-225, figs 159A- E.

Belaturricula ergata - Kantor and Harasewych 1999: 434; Engl 2012: 177, pl. 72, fig. 1.

Type locality: Off Shackleton Ice-shelf, Queen Mary Land, Antarctica, 65²0'S, 95² $27^{\prime} \mathrm{E}$, $439 \mathrm{~m}$.

Type material: Holotype: AMS (C.46689), SL 31.8 mm.

Material examined: Adélie Land, RV Aurora Australis, cruise CEAMARC, sta. 27EV45, 6601'S, 14243'E, 421-463 m (MNHN IM-2009-8165, 1 lv); Adélie Land, RV Aurora Australis, cruise CEAMARC, sta. 11EV429, 66³4'S, 14120'E, 170-210 m (MNHN IM-20098177, 1 lv); Adélie Land, RV Aurora Australis, cruise CEAMARC, sta. 87EV524, 65²9'S, 139¹9'E, 397-411 m (MNHN IM-2009-8189, 1 lv,). 
Morphology: Protoconch (Numanami 1996, fig. 159C) large, 2 slightly convex whorls, diameter $2.8 \mathrm{~mm}$, height $2.6 \mathrm{~mm}$, smooth, glossy white in color. Indistinct protoconchteleoconch transition marked by appearance of spiral sculpture.

Operculum (Egorova 1982, fig. 205) small, narrow oval, with nucleus strongly deflected to the right.

Radula (Fig. 3 J-L) of very long, slender, hypodermic marginal teeth with small rounded bases and two distinct, medium sized apical barbs. Distal opening of the tooth canal lateral, long, oval. Tooth length $1060 \mu \mathrm{m}$ (3.5\% of AL). A well-developed ligament maintains regular arrangement of teeth within the radular sac.

Remarks. This species had previously been referred to Pontiothauma E.A. Smith, 1895 (type species: Pontiothauma mirabile E.A. Smith, 1895), a member of the Raphitomidae, a family characterized by the lack of an operculum.

The radula of this large species, which reaches $100 \mathrm{~mm}$ in size (Engl 2012: 177), was first illustrated by Powell (1958) and Egorova (1982) as line drawings, and later by Hain (1990) and Numanami (1996) using electron micrographs. It is nearly identical to those of other species of Belaturricula. COI sequences of three specimens (Fig. 2) further support the transfer of this species to Belaturricula.

Distribution: Off Antarctica, from the Weddell Sea eastward to to the Dumont d'Urville Sea, 73-695 m, live 73-463 m (Numanami 1996: fig. 160, MNHN material).

Genus Drilliola Locard, 1897

Drilliola Locard 1897: 214. Type species (by monotypy): Taranis emendata Monterosato, 1872; Recent, Mediterranean.

Diagnosis: Shell small, attaining $12 \mathrm{~mm}$, claviform, with high spire and elongate-ovate last whorl, terminating in moderately long unnotched or shallowly notched siphonal canal. Protoconch $\sim 2$ 1/2 bicarinate whorls (type species) to conical multispiral with axial ribs. Teleoconch whorls weakly convex, subsutural ramp shallow, concave. Anal sinus moderately deep, U-shaped, with the deepest point slightly above the shoulder. Axial sculpture limited to crisp growth lines. Spiral sculpture of distinct, narrow, widely spaced spiral cords. Aperture moderately high, narrow oval.

Operculum present, small, with terminal nucleus.

Radula of long, slightly curved, hypodermic, pointed marginal teeth with very weak blade.

Remarks: This genus is known from the northern and central Atlantic Ocean and the Mediterranean Sea in the Recent fauna, as well as from Cenozoic deposits of northern Europe 
and New Zealand (Pacaud and Le Renard 1995; Schnetler and Palm 2008; Spencer et al. 2009). The Recent species, D. emendata and D. loprestiana (Calcara, 1841) differ markedly in shell shape and protoconch morphology (Bouchet and Warén 1980: figs 83, 207 for D. emendata, figs 82, 208-209 for D. lopresiana), Drilliola loprestiana seems more similar to species of Microdrillia Casey, 1903. Bouchet and Warén (1980: 32) considered Microdrillia to be a synonym of Drilliola, but both genera are recognized in current classifications (Bouchet et al. 2011).

Distribution: The range of this genus in the Recent fauna has been extended from the northern and central Atlantic and Mediterranean Sea to Antarctica with the description of the new species below.

<FIGURE 4 ABOUT HERE $>$

\section{Drilliola antarctica n. sp.}

(Fig. 4)

Turridae species 2 - Engl 2012: 190, pl. 78, fig, 5 a-b

Type material: Holotype: USNM 898821, South Shetland islands, Penguin Island, 6240'1.2"S, 5748'28.7994"W, USAP, RV Eltanin, 662-1120 m.

Description: Shell (Figs 4 A,B) small, narrow fusiform, fragile, with elevated spire and wide, attenuated siphonal canal. Protoconch and upper teleoconch whorls eroded. Remaining shell $\sim 61 / 2$ weakly convex whorls, slightly angulated at the shoulder. Suture shallow, weakly adpressed. subsutural ramp nearly flat. Axial sculpture limited to thin, narrowly spaced, slightly raised growth lines. Spiral sculpture of strong, narrow, raised cords, varying in prominence, separated by broader interspaces. Four narrow, irregularly spaced cords on subsutural ramp, 1 strong cord at shoulder producing an angulated profile for the whorls, 14 cords below shoulder and on siphonal canal, becoming more closely spaced along distal portions of the siphonal canal. Anal sinus wide, deep, nearly symmetrical, with deepest point slightly above shoulder cord.

Last whorl convex, comprising 0.6 of SL. Aperture moderately high, narrow, oval, comprising 0.5 of SL. Outer lip broken, showing spiral cords. Parietal region with narrow but thick callus, completely overlaying spiral sculpture. Columella smooth. Siphonal canal long, widely open, well differentiated from aperture, nearly straight. Shell color chalky white. 
Periostracum thin, peeling, olive and smooth. Operculum (Fig. 4 C) large, occupying nearly the entire aperture, narrow, oval, lower region including nucleus, abraded.

Dimensions: SL $11.6 \mathrm{~mm}$, BWL $6.9 \mathrm{~mm}$, AL $5.8 \mathrm{~mm}$, SW $4.2 \mathrm{~mm}$.

The dried tissues of the holotype were rehydrated. The body lacks pigmentation. Head well defined, small with short tentacles, eyes absent. Holotype is an adult male, penis very long, thick, spans entire mantle cavity, terminates in medium sized conical seminal papilla, not surrounded by fold. Proboscis straight, venom gland very short but thick, muscular bulb small. Radular sac very long, spanning nearly entire haemocoel. Radula (Fig. 4, D-F) of hypodermic marginal teeth, with short ligament and thin but strong subradular membrane maintaining radular integrity within the radula sac. Teeth long, around $270 \mu \mathrm{m}$ in length ( $4.7 \%$ of AL), base rounded, small, tooth canal opening long, subterminal. Tip with short cutting edge lacking barbs.

Remarks. The shell morphology of this new species is very similar to that of Drilliola emendata, the type species of the genus, although the erroded protoconch in the new species does not allow full comparison. The radula of $D$. antarctica is generally similar to that of $D$. emendata as illustrated by Bouchet and Warén (1980: fig. 29), but also resembles the radulae of many other Borsoniidae. Engl (2012: 190) noted the resemblance to this species to Drilliola emendata (Monterosato, 1872). Several fossil species from New Zealand are also attributed to Drilliola (Beu 2011).

Distribution: The species appears to be restricted to the South Shetland and South Orkney islands (Engl 2012).

\section{Genus Typhlodaphne Powell, 1951}

Typhlodaphne Powell 1951: 174. Type species (by original designation): Bela purissima Strebel, 1908; Recent, Antarctica.

Diagnosis: Shell medium sized, attaining $48 \mathrm{~mm}$, from elongate-ovate to narrowly fusiform, with high spire, narrow to moderately wide ovate last whorl and a wide, attenuated siphonal canal. Protoconch paucispiral, large, smooth, 2 whorls. Teleoconch whorls weakly to moderately convex, may be weakly angulated at shoulder, subsutural ramp shallow, concave. Anal sinus subsutural, shallow to moderately deep. Axial sculpture limited to growth lines, some thickened and more pronounced, producing appearance of irregularly spaced axial ribs. Spiral sculpture of cords that may be weak or obsolete in some species, covering entire shell. Aperture moderately high, narrow, oval.

Operculum present, small, with terminal nucleus. 
Radula of slightly curved hypodermic marginal teeth with small rounded bases and two medium sized apical barbs.

Remarks: Recent classifications have included as many as eight species in Typhlodaphne (Dell 1990: 239), four from Antarctic and four from subantarctic waters. Most have been transferred to other genera. We currently recognize two Antarctic species within this genus.

In the original description of Typhlodaphne, Powell (1951: 174, figs M, 92; N, 119, and N, 130) illustrated the radula, protoconch and operculum of the type species. He included this new genus in the subfamily Daphnellinae (=Raphitomidae A. Bellardi, 1875, fide Bouchet et al. 2011), "mainly on the evidence of the sinus, which is of a type seemingly exclusive to that subfamily" (Powell 1951: 174). This subfamilial placement was followed by subsequent authors (e.g., Powell 1966; Dell 1990; Numanami 1996). As a recent diagnosis of the Raphitomidae (Bouchet et al. 2011: 283) has shown that this family lacks an operculum, the genus Typhlodaphne was provisionally transferred to Borsoniidae (Bouchet et al. 2011: 278).

In addition to the Antarctic type species (Bela purrisima Strebel, 1908), Powell (1951) included in the genus Typhlodaphne two Patagonian taxa (Typhlodaphne strebeli Powell, 1951; Thesbia filostriata Strebel, 1905) as well as one subantarctic species (Pleurotoma (Thesbia) translucida Watson, 1881) from the Prince Edward islands. He later (Powell 1966: 129) added two species [Pleurotoma (Thesbia) corpulenta Watson, 1881; Pleurotoma (Thesbia) platamodes Watson, 1881] from off Kerguelen Island. Dell (1990) included the Patagonian species (Daphnella payeni Rochebrune \& Mabille, 1885) in Typhlodaphne, and described an additional species (T. innocentia Dell, 1990) from the Ross Sea.

Numanami (1996: 222) reported Pleurotoma (Thesbia) translucida Watson, 1881, from the coast of Antarctica, and transferred this species to Xanthodaphne on the basis of its radular morphology [see below as Xanthodaphne translucida]. We here transfer Typhlodaphne innocentia Dell, 1990, to Pleurotomella, on the basis of shell morphology [see below under Pleurotomella innocentia].

Based solely on shell morphology, the subantarctic species $P$. corpulenta and $P$. platamodes, and the Patagonian species $D$. payeni most closely resemble $P$. translucida, and likely are also referable to Xanthodaphne. The Patagonian species T. filostriosa and T. strebeli (Fig. 5 K-L) are provisionally retained in Typhlodaphne pending additional data on radular morphology or molecular sequences.

Distribution: Magellanic, Antarctic, 90-2850 m.

\section{<FIGURE 5 ABOUT HERE $>$}




\section{Typhlodaphne purissima (Strebel, 1908)}

(Figs 5 A-J, 6 A-F)

Bela purissima Strebel 1908: 17-18, pl. 3, fig. 31 a-d.

Typhlodaphne purissima. - Powell 1951: 174, figs M 92,051

62 N 119, N 130; Castellanos and Landoni 1993 (part.): 13, non pl. 3, fig. 29 a-b (= Typhlodaphne strebeli Powell, 1951); Zelaya 2005: 128, fig. 54.

Type locality: Shag Rock Bank, 5334'S, 4323'W, 160 m, Swedischen SüdpolarExpedition, sta. 17.

Type material: Syntypes: three syntypes, SMNH Type-1061 (Fig. 5 A-F). Two live collected specimens, one dead broken shell.

Material examined: off South Georgia Island, RV Isla Orcada, cruise 575, sta. 14,

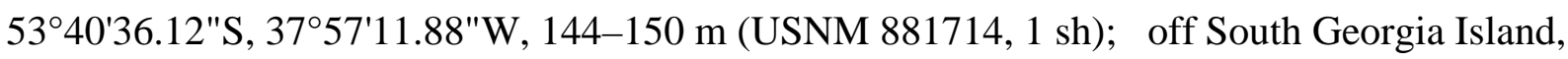

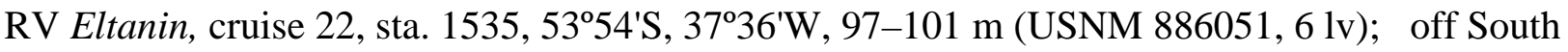
Georgia Island, RV Isla Orcada, cruise 575, sta. 17, 53³6'S, 38³'W, 122-124 m (USNM 894454, 4 sh); off South Georgia Island, RV Professor Siedlecki, cruise 86-01, sta. 58, 53ํ16'12"S, 3543'12"W, 180-186 m (USNM 897551, 1 lv); off South Georgia Island, RV Eltanin, cruise 9, sta. 686, 54' 59 'S, 38²13'W, 2196-2379 m (USNM 896362, 2 lv); NE of South Georgia Island, RV Eltanin, cruise 9, sta. 726, 5253'S, 3352'W, 2818-2855 m (USNM 896521, $1 \mathrm{lv}$,$) .$

Morphology: Protoconch (Fig. 5 F) smooth, rather large, diameter 1.65 mm, height 1.3 mm, 2 rounded whorls. Operculum (Fig. 5 D) small, comprising 0.25 of aperture length, leafshaped, translucent, with the subterminal nucleus situated at the lower-right.

Radula (Figs 6 A-C) of hypodermic marginal teeth, with distinct ligament and thin, strong subradular membrane maintaining radular integrity within the radula sac. Tooth base rounded, apical opening large, oval, lateral. Tip of tooth armed with two sharp barbs, one immediately distal to apical opening, the other lateral and proximal to opening. Tooth length $\sim 310 \mu \mathrm{m}(2.4 \%$ of AL).

Remarks: The syntypes of this species are nearly smooth, except for fine growth lines, indistinct spiral riblets, and several faint, strongly oblique, irregularly spaced riblets along the upper teleoconch whorls. Some specimens collected off South Georgia (USNM 897551) at similar depths have more pronounced oblique ribs that extend onto the last whorl (eg. Fig. 5 G).

While the majority of examined specimens were collected at outer continental shelf depths (97-186 m), two records were from depths in excess of 2,000 m (Fig. 5 H-J). These deep-water 
specimens resemble the shallow water records in general morphology, but have slightly thinner shells, more pronounced spiral sculpture, axial ribs parallel to growth striae, and shoulders that become more pronounced with increasing depth. The radula of a deep-water specimen (Fig. 6 DF) [tooth length $\sim 310 \mu \mathrm{m}(2.4 \%$ of $\mathrm{AL})$ ] is similar to those from shallow water, but has shorter, more obtuse barbs. At present, we provisionally regard these specimens as deep-water phenotypes of $T$. purissima, but recognize that additional data may show them to be an undescribed species.

\section{<FIGURE 6 ABOUT HERE>}

With their pronounced axial ribs, these deep-water specimens somewhat resemble the Pategonian species Typhlodaphne strebeli Powell, 1951 (holotype, NHMUK 1961617 from off Cape Horn - Fig. 5 K-L), also from outer shelf depths. Conchological differences between $T$. purissima and T. strebeli are subtle, with $T$. strebeli distinguished on the basis of its buff color, slightly more slender shell with a smaller protoconch and the presence of oblique ribs.

In his description of T. strebeli, Powell (1951: 175) listed, but did not further discuss, a second specimen from the type locality of T. purrisima (This specimen could not be located in the collections at NHMUK, A. Salvador, personal communication). At present, we consider $T$. purissima and T. strebeli to be different species.

Distribution: South Georgia and Shag Rock Bank, live 94-2380 m. Zelaya (2005) considered the reports of this species from off Argentina and Tierra del Fuego (Carcelles 1944; Castellanos and Landoni 1993) to be referrable to T. strebeli Powell, 1951.

\section{Typhlodaphne paratenoceras (Powell, 1951), n. comb.}

(Figs 6 G-M; 7 A-K)

Leucosyrinx paratenoceras Powell 1951: 168-169, pl. 9, fig. 54; Castellanos and Landoni 1993: 6, pl. 3, fig. 21; Troncoso and Aldea 2008: 1261.

Type locality: Discovery sta. 1952, between Penguin Island and Lion’s Rump, King George Island, South Shetland islands, 367-382 m.

Type material: Holotype: NHMUK 1961607, SL 38.75 mm (Fig. 7 A-C).

Material examined: South Orkney islands, of North Laurie Island, RV Eastwind, cruise 66, 60³1'12"S, 44 46' 48"W, 761 m (USNM 678478, 1 lv2 sh); South Shetland islands, W of

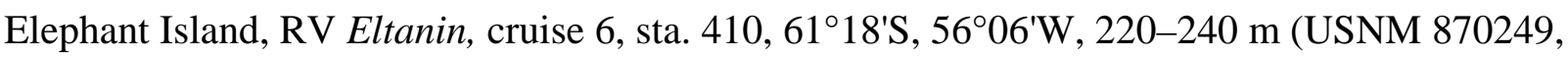




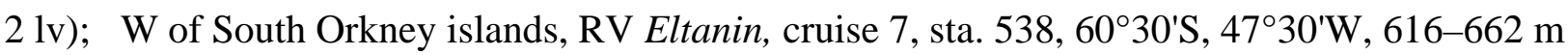
(USNM 870328, 2 sh); Antarctic Peninsula, Graham Land, NE of Joinville Island, RV Eltanin,

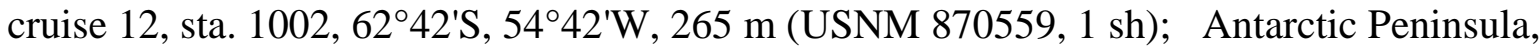
Graham Land, NE of Joinville Island, RV Eltanin, cruise 12, sta. 1003, 62 ${ }^{\circ} 42^{\prime} \mathrm{S}, 5^{\circ} 42^{\prime} \mathrm{W}, 210$ 220 m (USNM 870608, 1 sh); Scotia Ridge, SE of South Orkney islands, RV Eltanin, cruise 12, sta. $1078,61^{\circ} 24^{\prime} \mathrm{S}, 41^{\circ} 54^{\prime} \mathrm{W}, 604 \mathrm{~m}$ (USNM 870613, $1 \mathrm{sh}$ ); Scotia Ridge, SE of South

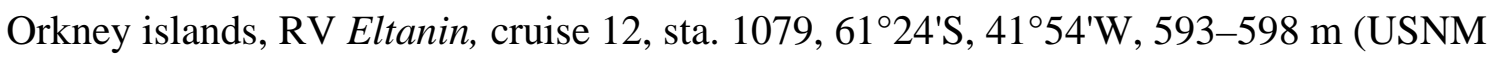
870629, $10 \mathrm{lv,} \mathrm{one} \mathrm{radula} \mathrm{examined);} \mathrm{South} \mathrm{Orkney} \mathrm{islands,} \mathrm{Scotia} \mathrm{Ridge,} \mathrm{RV} \mathrm{Eltanin,} \mathrm{cruise}$ 12, sta. 1084, 60²4'S, 4654'W, 298-403 m (USNM 870640, 1 sh); South Orkney islands, Inaccessible Island, RV Islas Orcadas, cruise 876, sta. 113, 60³0'S, 46²4'12"W, 124-128 m (USNM 894445, 1 sh); South Orkney islands, RV Islas Orcadas, cruise 876, sta. 118, 62 ${ }^{\circ} 48^{\prime \prime S}, 43^{\circ} 06^{\prime} \mathrm{W}, 759-857 \mathrm{~m}$ (USNM 894461, $1 \mathrm{sh}$ ); South Orkney islands, Coronation Island, RV Islas Orcadas, cruise 876, sta. 108, 60²5'48"S, 46²3'24"W, 152-159 m (USNM 894467, 1 sh); South Orkney islands, Laurie Island, RV Islas Orcadas, cruise 876, sta. 129, 6057'S, 44²4'W, 225-234 m (USNM 894479, 1 sh); Scotia Ridge, SE of South Orkney

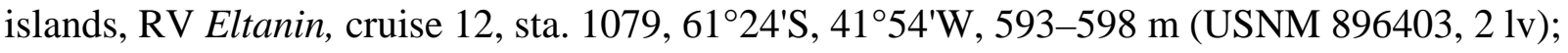
South Shetland islands, Deception Island, RV Hero, cruise 833, sta. 2, 6254'36"S, 60³0'W, 130-210 m (USNM 897549, 1 lv,).

\section{<FIGURE 7 ABOUT HERE>}

Morphology: Protoconch smooth, rather large, $\sim 2$ rounded whorls, diameter $\sim 2.1 \mathrm{~mm}$, height $\sim 1.7 \mathrm{~mm}$. Operculum (Fig. $6 \mathrm{~J}$ ) present, large, narrow, occupying $\sim 1 / 2$ of aperture, with terminal nucleus very slightly shifted to right.

Radula (Fig. 6 G-I, K-M) of hypodermic marginal teeth. Subradular membrane vestigial. Teeth straight, with medium sized swollen base and lateral basal opening of tooth canal. Teeth attached to membrane by distinct ligament. Apical opening with small sharp distal barb and another larger, obtuse barb at proximal end of opening of tooth canal. Teeth length $\sim 320 \mu \mathrm{m}$ long (1.08\% of SL).

Remarks: Typhlodaphne paratenoceras was described in the genus Leucosyrinx entirely on conchological grounds. Powell (1951: 168) stated: "I have included the two following species (Leucosyrinx paratenoceras and L. paragenota) in Leucosyrinx in preference to Aforia because the anal sinus is wide, occupying most of the shoulder, and the species lack the strong peripheral carina which is so characteristic of Aforia. Unfortunately, none of the specimens contained the animal. Both Aforia and Leucosyrinx belong to the subfamily Cochlespirinae." 
The genus Leucosyrinx Dall, 1889 (type species Pleurotoma verrillii Dall, 1881) as currently accepted (Bouchet et al. 2011) belongs to the family Pseudomelatomidae, which is characterized by a radula of non-hypodermic duplex marginal teeth and the absence of a central tooth. As the radula of "Leucosyrinx" paratenoceras is comprised of hypodermic marginal teeth, this species cannot be attributed to Pseudomelatomidae, or to Leucosyrinx. Radular morphology suggests this species is referable to the family Borsoniidae. The morphology of its shell is most similar to that of Typhlodaphne purissima, sharing such features as large size (reaching $45 \mathrm{~mm}$ in T. paratenoceras, $32 \mathrm{~mm}$ in T. purissima), narrow shell, high spire and slightly concave subsutural ramp, and similarly shaped subsutural anal sinus with its deepest point around the midpoint of subsutural ramp. Typhlodaphne paratenoceras has more pronounced spiral sculpture, comprised of closely spaced spiral cords, while T. purissima has faint spiral striations that are best observed in oblique light. The operculum of T. paratenoceras is larger in proportion to the shell, spanning 1/2 the aperture length, compared to $1 / 4$ the aperture length in $T$. purissima. The radulae of both species are remarkably similar. However, the barb below the apical opening of the tooth canal is pointed in T. purissima, obtuse in T. paratenoceras.

Distribution: Bellingshausen, Scotia and Weddell Seas, $60^{\circ} 22^{\prime} \mathrm{S}$ to $64^{\circ} 21 \mathrm{~S}$; $41^{\circ} 55^{\prime} \mathrm{W}$ to 6258'W; 124-857 m, live 130-761 m (USNM materials).

\section{Typhlodaphne cf paratenoceras (Powell, 1951)}

(Fig. 6 N-R, 7 L-O)

Material examined: Scotia Sea, RV Eltanin, cruise 22, sta. 1511, 5900'S, 515' W, 3010-3510 m (USNM 1113019, 3 sh); (USNM 1113020, 2 lv,).

Several specimens from the Scotia Sea were collected at substantially greater depths (>2800 $\mathrm{m}$ ) than the majority of records for this species (124-857 m). Conchologically these specimens fall within the range of variability of T. paratenoceras. The operculum (Fig. $6 \mathrm{R}$ ) differs in having its nucleus deflected to right, more so than in shallow water specimens (Fig. 6 J). Radular teeth (Fig. $6 \mathrm{~N}-\mathrm{Q}$ ) are very similar to those of T. paratenoceras in general shape and size (teeth length $490 \mu \mathrm{m}$, or $1.08 \%$ of SL), but differ in having a reduced lower apical barb. We provisionally attribute these specimens to Typhlodaphne cf paratenoceras, recognizing that additional material may warrant segregating the abyssal population as a separate species. 


\section{Family MANGELIIDAE P. Fischer, 1883}

\section{Genus Lorabela Powell, 1951}

Lorabela Powell 1951: 171. Type species (by original designation): Bela pelseneri Strebel, 1908; Recent Antarctica.

Diagnosis: Shell small, attaining $11.5 \mathrm{~mm}$, ovate-biconic, with low spire, high, strongly convex last whorl and short, wide siphonal canal. Protoconch medium sized, $\sim 2$ convex, smooth or finely granulated whorls. Teleoconch whorls convex, evently rounded or angulated at shoulder, subsutural ramp weakly concave to nearly straight. Anal sinus subsutural, shallow, with the deepest point on subsutural ramp. Axial sculpture of sharp, narrow, arcuate ribs. Spiral sculpture of subequal, dense spiral cords or, in some species, of inconspicuous riblets, covering the entire shell. Aperture moderately high, narrow ovate-pyriform.

Operculum present, small, with terminal nucleus.

Radula of short, hypodermic, marginal teeth with long base and lateral basal opening, without barb at the tip.

Remarks: Four species, all Antarctic, are currently recognized in Lorabela. Bela notophila Strebel, 1908 was attributed to Lorabela by Powell (1951), but has been transferred to a new, monotypical genus Strebela Kantor and Harasewych, 2013 (Buccinulidae).

There is a conspicuous similarity among several Antarctic species and boreal "Oenopotinae" in the morphologies of their shell, protoconch, radula and in the presence of an operculum. In his description of Lorabela, Powell (1951) noted its similarity to the boreal genus Propebela Iredale, 1918. Bouchet and Warén (1980) synonymized 12 genera with Oenopota, among them Lorabela Powell, 1951 and Belalora Powell, 1951, from Antarctric and Magellanic waters. Bogdanov (1987) subsequently erected the subfamily Oenopotinae, and later (1990) revised the northern genera and species of this subfamily, recognizing five genera and four subgenera. Bouchet et al. (2011: 281) synonymized Oenopotinae with Mangeliidae, and listed Lorabela and Belalora as questionable synonyms of Propebela. Beu (2011) discussed the position of several Recent and fossil turrids from New Zealand in some detail, and treated Lorabela, Belalora, Antiguraleus Powell 1942 and Paraguraleus Powell 1944 as synonyms of Propebela. Most recently, Engl (2012) followed Bouchet and Warén (1980) in synonimizing Lorabela and Belalora with Oenopota.

Phylogenetic analyses (Fig. 8) of new COI sequence data from three specimens of Lorabela and a selection of previously sequenced taxa now assigned to Mangeliidae (Puillandre et al. 2011), revealed Propebela to be more closely related to Toxicochlespira Sysoev \& Kantor, 
1990 from the western Pacific than to Lorabela. Based on morphological data, Lundberg et al. (1996) showed that most Propebela (including the type species Murex turricula Montagu, 1803) form a monophyletic group within the "Oenopota/Propebela complex". Therefore, despite the conchological and radular similarities of Lorabela (and Belalora) to boreal “oenopotine” genera, we treat these two Antarctic/subantarctic genera as distinct .

Distribution: Antarctica, 98-650 m.

\section{<FIGURE 8 ABOUT HERE>}

\section{Lorabela pelseneri (Strebel, 1908)}

(Fig. 9 A-C)

Bela pelseneri Strebel 1908: 15-16, pl. 2, fig. 27 a-b.

Lorabela pelseneri. - Powell 1951: 171; Powell 1966: pl. 19, fig. 14; Castellanos and Landoni 1993: 20, pl. 2, fig. 15.

Lorabela pelseneeri. - Hain 1990: 70, pl. 8, fig. 1, pl. 26, fig. 5; Zelaya 2005: 128, fig. 50 (text and figure captions erroneously refer to fig. 52; which represents "Bela" fulvicans); Numanami 1996: 211.

Oenopota pelseneri. - Engl 2012: 182, pl. 74, fig. 3 (lectotype).

Type locality: Outer Cumberland Bay, South Georgia Island, $54^{\circ} 11^{\prime} \mathrm{S}, 36^{\circ} 18^{\prime} \mathrm{W}$, in $252-$ 310 m, Swedischen Südpolar-Expedition, sta. 34.

Type material: Lectotype (designated by Engl 2012: 182, pl. 74, fig. 3), SMNH Type1065, SL 7.6 mm, 2 paralectotypes SMNH Type-5762 (from type locality).

Material examined: Type material; off South Georgia Island, RV Eltanin Cruise 22, sta. 1535, 53.9 ${ }^{\circ}$ S, 37.6º W, 97-101 m (USNM 886042, 1 lv); off Antarctic Peninsula, 6340'4.8"S, 57018'56.4"W, 260 m (USNM 1121974, 1 lv, sequenced).

Morphology: The protoconch was eroded on all available specimens. Powell (1951: 171) reported the operculum to be vestigial, thin, oval, with a terminal nucleus. Although the lectotype lacks an operculum, the scar of the opercular disc on the dorsal part of the foot is clearly seen (Engl 2012: pl. 74, fig. 3). The radula was illustrated by Hain (1990: pl. 26, fig. 5) as having short, hypodermic marginal teeth with a long base, a large, oval, lateral basal opening and a medium sized lateral apical opening of the tooth canal.

Remarks: The sequenced specimen (USNM 1121974 - Fig. 9C) from the Antarctic Peninsula differs from the lectotype (Fig. 9A) in having a narrower shell with a more attenuated base. It more closely resembles the paralectotype (Fig. 9B). 
Distribution: South Georgia, the Bransfield Strait and the Weddell Sea, in 98-310 m (Powell 1951; Engl 2012).

<FIGURE 9 ABOUT HERE>

\section{Lorabela glacialis (Thiele, 1912)}

(Fig. 9 D-I)

Bela glacialis Thiele 1912: 215, pl. 14, fig. 5.

Typhlodaphne glacialis. - Egorova 1982: 51, fig. 212.

Oenopota glacialis. - Engl 2012: 182, pl. 74, figs 1a-b.

Type locality: Gauss-Station, Davis Sea, 6602'09"S, 89³8'E, 385 m.

Type material: 9 syntypes, ZMB Mol 62985.

Material examined: The type material.

Morphology: The protoconch (Fig. 9 F) is paucispiral, $~ 2$ smooth, rounded whorls, (diameter $1.33 \mathrm{~mm}$, height $0.98 \mathrm{~mm}$ in one of syntypes). The animal is unknown.

Remarks: No new records of this species have been reported since it was described. Egorova's (1982) treatment of this taxon is based on Thiele's description.

Distribution: Known only from the type locality.

\section{Lorabela plicatula (Thiele, 1912)}

(Fig. 9 J-R)

Bela plicatula Thiele 1912: 215, pl. 14, fig. 4;.

Lorabela plicatula. - Powell 1951: 171; 1958: 202; 1960: 159; 1966: 122; Egorova 1982: 48, fig. 203 (based on published data only); Hain 1990: 71, pl. 8, fig. 2 (shell), pl. 26, fig. 6 (radula); Numanami 1996: 210-211, figs 146A-D.

Oenopota plicatula. - Engl 2012: 182-183, pl. 74, figs 4a-b. not Lorabela plicatula sensu Dell 1990: 238, figs 405, 407.

Type locality: Gauss-Station, Davis Sea, 6602'09"S, 89³8'E, in 385 m.

Type material: 6 syntypes, ZMB Mol 62986. 
Material examined: type material; off Antarctic Peninsula, 6340'4.8"S, 57²18'56.52"W, 260 m (USNM 1121967, 1 lv, sequenced); off Antarctic Peninsula, 63²40'4.8"S, 57²18'56.52"W, 260 m (USNM 1121969, 1 lv, sequenced).

Morphology: Protoconch paucispiral, $\sim 2$ rounded whorls, with dense spiral rows of micropustules and narrow, prosocyrt, axial ribs on the last $1 / 5$ whorl. Diameter $1.0 \mathrm{~mm}$, height $0.86 \mathrm{~mm}$ in syntype (Fig. $9 \mathrm{~L}$ ); diameter 1.1, height $0.99 \mathrm{~mm}$ (Numanami 1996: fig. 146C). Operculum absent (Numanami 1996: 210).

Radula (Fig. 9 P-R) of hypodermic marginal teeth with long, solid, transversely striated base spanning $1 / 5$ of tooth length. Tooth long [230 $\mu \mathrm{m}, \approx 4.2 \%$ of aperture length (AL) without siphonal canal], with well pronounced spur. Basal opening of tooth canal large oval, lateral, distal opening narrow, elongate, lateral. Long blade present along distal third of tooth opposite the distal opening, barbs absent.

Remarks: Syntypes of L. plicatula are immature, dead collected and slightly worn specimens, the largest $6.2 \mathrm{~mm}$ in length. The largest specimen we examined was $11 \mathrm{~mm}$ in length (Fig. 9 O). Lorabela plicatula is similar conchologically to L. glacialis and some of the syntypes of both species can hardly be differentiated (eg. Figs 9 D and $9 \mathrm{~J}$ ).

Lorabela glacialis and L. plicatula occur in sympatry, but may be distinguished by presence of a stronger shoulder with a more gently sloping subsutural ramp in L. plicatula, as well as by its slightly smaller protoconch [L. plicatula $\mathrm{D}=1.0 \mathrm{~mm}, \mathrm{H}=0.86 \mathrm{~mm}$ vs $\mathrm{D}=1.3, \mathrm{H}=$ 0.98 in one syntype of $L$. glacialis).

COI sequence data (Fig. 8) demonstrate a close relationship between $L$. plicatula and $L$. pelseneri that were collected sympatrically.

Dell (1990: figs 405, 407) mistakenly illustrated a buccinulid species, probably "Pareuthria" plicatula Thiele, 1912 (the generic position of this species is still unressolved - see Kantor and Harasewych 2013).

Distribution: Ross Sea, off Enderby Land, off Adelie Land; Weddell Sea, 155-640 m, live 260270 m (Numanami 1996; USNM material).

\section{Lorabela davisi (Hedley, 1916)}

(Fig. 9 S)

Oenopota davisi Hedley 1916: 54, pl. 8, fig. 84; Engl 2012: 181-182, pl. 74, fig. 2.

Lorabela davisi. - Powell 1958: 202; 1960: 159; 1966: 122; Dell 1990: 238, figs 408, 409;

Numanami 1996: 208, figs 144A-D.

Turridae sp. 2 - Hain 1990: 73, pl. 8, fig. 8, pl. 27, fig. 4. 
not Lorabela davisi - Egorova 1982: 47, fig. 202.

Type locality: RV Aurora, sta. II, off Mertz Glacier tongue, Adelie Land, 66 52'S, $145^{\circ} 30^{\prime} \mathrm{E}, 527 \mathrm{~m}$.

Type material: Holotype, AMS (C.46688), SL 7.0 mm.

Material examined: no material available.

Morphology: Protoconch (Numanami 1996: fig. 144C) (diameter $1.3 \mathrm{~mm}$, height $1.0 \mathrm{~mm}$ ) wide, conical, $\sim 2$ finely granulated, evenly rounded, convex whorls with very thin, nearly orthocline growth striae on last $1 / 4$ whorl. Transition to teleoconch marked by sinuous axial rib. Operculum absent (Numanami 1996: 209). The radula was illustrated by Hain (1990: pl. 27, fig. 4) and Numanami (1996: fig. 144D). Marginal hypodermic teeth long ( $250 \mu \mathrm{m}, \approx 2.2 \%$ of AL), loosely enrolled, with long base, spanning 1/4 of tooth length. Basal opening of tooth canal large, oval, lateral, with distinct spur, distal opening lateral, long.

Remarks: The holotype is a juvenile specimen. This species attains a length of $16.5 \mathrm{~mm}$ (Numanami 1996). Although Hedley (1916: 54) only compared L. davisi to L. plicatula, it more closely resembles L. glacialis, a similarity noted by Engl (2012: 182). Specimens of L. davisi, illustrated by Dell (1990: fig. 408) and Numanami (1996: fig. 144 A-B) appear intermediate between the holotype of $L$. davisi and syntypes of L. glacialis raising the possibility that these two taxa may be conspecific.

Egorova (1982) reported three specimens of L. davisi, reaching $24.8 \mathrm{~mm}$, from $540 \mathrm{~m}$ in the Davis Sea. However, her illustration of the shell (Egorova 1982: fig. 202) differs substantially from the type of L. davisi (Engl 2012: pl. 74, fig. 2). She also described the radula (p. 48) as having duplex rather than hypodermic marginal teeth, which precludes the inclusion of her sample in Mangeliidae. Her specimen may represent a juvenile of Conorbela antarctica.

Distribution: From the western Weddell Sea, Enderby Land, Adelie Land and the Ross Sea, in 193-640 m (Dell 1990; Numanami 1996).

\section{Genus Belalora Powell, 1951}

Belalora Powell 1951: 171. Type species (by original designation): Belalora thielei Powell, 1951; Recent, Magellanic.

Diagnosis: Shell small, attaining $7 \mathrm{~mm}$, ovate-biconic, with low spire, high last whorl and short, wide siphonal canal. Protoconch large, dome-shaped, 3 whorls, initial part smooth and flattened, followed by a whorl of closely spaced spiral threads and, finally, a whorl of spiral ribs crossed by axial threads. Teleoconch whorls convex, may be strongly angulated at shoulder. 
Subsutural ramp concave to weakly convex. Anal sinus subsutural, moderately shallow to deep. Axial sculpture of sharp, narrow, oblique and arcuate ribs. Spiral sculpture of cords of varying size covering entire shell. Aperture moderately high, narrow, ovate-pyriform.

Operculum present, small, with terminal nucleus.

Radula of short hypodermic marginal teeth with very wide basal opening and distinct barb at the tip.

Remarks: Three species are currently recognized in the genus Belalora. The type species is from off the northwestern coast of the Falkland islands, the remaining two species are from off Antarctica.

In his description of the genus Belalora, Powell (1951: 171) noted that it resembled the Arctic genus Propebela in shape and sculpture of the teleoconch, but differed in having a characteristic protoconch. Protoconchs of several species of Propebela are similar (see Bogdanov 1990: figs 401-403), and the radula of Belalora striatula (Hain 1990: pl. 26, fig. 7) resembles those of Propebela spitzbergensis (Friele, 1886), P. svetlanae Bogdanov, 1989, and others (see Bogdanov 1990: figs 432, 435). A small, oval operculum with a terminal nucleus is present in Propebela.

As was demonstrated for representatives of the closely related genus Lorabela (see above) molecular data do not support a close relationship between Antarctic species and north Atlantic/Arctic Propebela. Despite morphological similarities with the genus Propebela, we provisionally retain Belalora as a separate genus. Further molecular studies will be needed to resolve this issue.

Distribution: Magellanic Region, Antarctica, in 160-4800 m.

<FIGURE 10 ABOUT HERE>

\section{Belalora striatula (Thiele, 1912)}

(Fig. $10 \mathrm{~A}-\mathrm{F}$ )

Bela striatula Thiele 1912: 215, pl. 14, fig. 3.

Belalora striatula. - Powell 1951: 171; 1960: 159; 1966: 122; Egorova 1982 (part.): 48, figs 207, 208 (not fig. 61); Dell 1990: 236, figs 421, 422; Hain 1990: 71, pl. 8, fig. 3, pl. 26, fig. 7. Oenopota striatula. - Schwabe et al. 2007: 1838 (record only).

Type locality: Gauss-Station, Davis Sea, 6602'09"S, 89³8'E, 385 m.

Type material: 6 syntypes, ZMB Mol 62987. 
Material examined: type material; Ross Sea, McMurdo Sound, Deep Freeze I, sta. ED-8, 77²1'S, 169³0' E; 321 m (1 sh, USNM 612782).

Morphology: Protoconch (Fig. 10 C) 3 whorls, first one smooth and flattened, remaining whorls convex with 8-9 narrow distinct, widely spaced spiral cords. Protoconch/teleoconch border is marked by appearance of narrow axial ribs. Protoconch diameter $-1.5 \mathrm{~mm}$, height -1.3 mm. The radula (Hain 1990: pl. 26, fig. 7) consists of hypodermic marginal teeth that are short $(\approx 17 \mu \mathrm{m})$, with a very wide $(\approx 4.5 \mu \mathrm{m})$, nearly teminal basal opening, well developed spur and distinct barb at the tip. Apical opening of tooth canal lateral, small, oval, below the barb. Operculum small, with terminal nucleus (Powell 1951: 171).

Remarks. This species is easily recognizable on the basis of its characteristic shell and protoconch. Egorova (1982: figs 207, 208) illustrated the shell and operculum of this species. However, her description and illustration of the radula (fig. 61) does not correspond to Hain's (1990) subsequent micrograph, but rather depicts paired duplex teeth, characteristic of the family Pseudomelatomidae or Horaiclavidae.

Distribution: Davis Sea, Enderby Land, Ross Sea, Weddell Sea, 193-752 m (Powell 1960; Dell 1990; Engl 2012).

\section{Belalora weirichi (Engl, 2008), comb. nov.}

(Fig. $10 \mathrm{G}-\mathrm{J}$ )

Oenopota weirichi Engl 2008a: 50, 52, figs 1-6; Engl 2012: 183, pl. 74, figs 6a-c.

Type locality: Weddell Abyssal Plain, 653․ 34 'S $-36^{\circ} 31.18^{\prime} \mathrm{W}-65^{\circ} 35.72$ 'S $-36^{\circ} 28.40^{\prime} \mathrm{W}$, 4,794-4,805 m (RV Polarstern ANT 22/3, sta. 102-11).

Type material: Holotype: ZSM Mol 2005 1067, SL 7 mm.

Material examined: no material was available.

Morphology: Protoconch eroded in specimens described by Engl (2008: figs 3, 4; herein, Fig. $10 \mathrm{I}-\mathrm{J})$, of 3 protoconch whorls, only the last one retained sculpture, consising of 11 subequal spiral cords, similar to the protoconch of other species of the genus. Diameter $1.25 \mathrm{~mm}$, height 1,18 mm. Radula unknown. Eyes and operculum are absent.

Remark: Although Engl proposed this species in the genus Oenopota, its protoconch and shell shape suggest a close affinity to Belalora. We transfer this species to Belalora, pending additional information on its radular morphology,

Distribution: Weddell Abyssal Plain, live 1,812-4,805 m. 


\section{Genus Pleurotomella Verrill, 1872}

\section{Subgenus Pleurotomella (Pleurotomella) Verrill, 1872}

Pleurotomella Verrill 1872: 15. Type species (by monotypy): Pleurotomella packardi Verrill, 1872; Recent, Northeastern United States.

Diagnosis: Shell extremely variable, from 4 to $75 \mathrm{~mm}$, with short to medium high spire and large convex or angulated last whorl and short to long siphonal canal. Protoconch multispiral, up to nearly 5 whorls, strongly ornamented either with axial cords, or diagonally cancellated. Teleoconch whorls convex, evently rounded or angulated at shoulder, subsutural ramp from weakly concave to nearly straight or even weakly convex. Anal sinus subsutural, shallow, with the deepest point on subsutural ramp. Axial sculpture rxtremely variable, ranging from absent to strongly arcuate varices. Spiral sculpture of variable cords or keels. Aperture from medium to high, widely ovate or ovate-pyriform.

Operculum absent (in all Raphitomidae).

Radula of short hypodermic marginal teeth wih large base and wide basal opening, with or without barb(s) at the tip.

Remarks. Seventy three species of Pleurotomella are currently recognized as valid (Bouchet and Gofas 2014, no subgenera recognized). Two species of the nominotypical subgenus, including one new species described herein, are recorded from Antarctic waters. Another 12 species from Antarctic waters, of which one is described as new, are referred to the subgenus Pleurotomella (Anomalotomella) Powell, 1966.

Powell (1966) established the subgenus Anomalotomella for a group of subantarctic Antarctic species that differ from typical Pleurotomella (which have a multispiral diagonally cancellated protoconch) in having a paucispiral protoconch of two whorls. The validity of the subgenus was questioned by Beu (2011), who synonymized Anomalotomella with Pleurotomella s.s., and this opinion was accepted in Gofas (2015).

The shift from a multispiral protoconch (the plesiomorphic state within Raphitomidae) to a paucispiral protoconch was analyzed within a shallow water complex of Indo-Pacific raphitomids (Kermia-Pseudodaphnella) based on a molecular phylogeny (Fedosov and Puillandre 2012). The results demonstrated convincingly that changes in the mode of development occurred several times within the group. Antarctic and subantarctic species of Pleurotomella with non-planktotrophic development (indicated by a paucispiral protoconch) are derived from species with multispiral protoconchs and plantotrophic development that have only recently been discovered in Antarctic waters (Engl 2008b; herein). It is not clear whether this shift in developmental mode occurred once and resulted in an adaptive radiation that gave rise to 
a monophyletic Anomalotomella, or whether, as in the tropics, the shift occurred in multiple, independent lineages. The latter premise seems less parsimonious. There are only two Recent Antarctic species with planktotrophic protoconch that we attribute to Pleurotomella. None are present in the Magellanic fauna (Castellanos and Landoni 1993) or the fauna of New Zealand (Spencer et al. 2009). Nor are their any Raphitomidae in the Antarctica fossil record (Beu 2009). Since most of raphitomids have thin shells, their absence in fossil deposits may be an artefact of preservation. There are few species with planctotrophic development that could have given rise to multiple lineages of Pleurotomella with non-planctotrophic development. Future molecular studies may clarify the situation and further subdivide Anomalotomella.

Distribution: Atlantic, Indo-Pacific, Magellanic, Antarctic, in bathyal to abyssal depths.

<FIGURE 11 ABOUT HERE>

\section{Pleurotomella (Pleurotomella) maitasi Engl, 2008}

(Fig. $11 \mathrm{~A}-\mathrm{D})$

Pleurotomella maitasi Engl 2008b: 57-58, figs 1-2; Engl 2012: 187, pl. 77, fig. 2a-b (holotype).

Type locality: East of South Sandwich islands, from $58^{\circ} 15.07^{\prime} \mathrm{S}-24^{\circ} 22.03^{\prime} \mathrm{W}$ to 58¹5.31'S-2421.20'W, 3931-3948 m, Polarstern ATN XIX/4 (AN-DEEP II) Exp., sta. 139-5.

Type material: Holotype: ZSM Mol 2006 2201, SL 8 mm.

Material examined: IORAS, 3 lv, Scotia Sea, RV Akademik Kurchatov, st. 914, 56²1'S, 5048'W, 5700-5650 m (Fig. 11 A-D).

Morphology: Protoconch 3 whorls, first whorl (protoconch I), smooth, brownish, adpressed, remaining whorls (protoconch II) beige, covered with closely spaced, irregularly shaped, meandering axial ribs, more distinct on last protoconch whorl, which also bears indistinct oblique spiral cords. Protoconch/teleoconch transition (Fig. 11 H-I, arrow) marked by appearance of growth lines and axial folds and distinctive spiral sculpture of widely spaced, raised spiral cords. Protoconch height $880 \mu \mathrm{m}$ (around $0.9 \mathrm{~mm}$ in holotype), diameter $1.0 \mathrm{~mm}$

One specimen was dissected. Head bulbous, with short tentacles, eyes absent. Very large rhynchostomal sphincter present anteriorly that may also comprise short, strongly contracted introvert. Proboscis straight, of medium length, with very strongly contracted walls, septum surrounding proboscis base. Venom gland short but thick, muscular bulb small and oval. Oesophagus very thick. Radula $\sim 20$ rows of teeth, radular sac very short relative to anterior foregut. 
Radula of simple, hypodermic marginal teeth. Subradular membrane maintains radular integrity in the radular sac. Teeth small, $\sim 60 \mu \mathrm{m}$ long ( $0.9 \%$ of AL without siphonal canal), straight. Tooth canal opening at tooth base laterally. Apical opening lateral, long, narrow oval. No barbs or blade. Tooth with short, blunt spur above the basal opening.

Distribution: Scotia Sea, live 3900-5700 m.

\section{Pleurotomella (Pleutoromella) tippetti n. sp.}

(Fig. 11 E-J)

Oenopota sp. - Schwabe et al. 2007: 1836.

Turridae species 1 - Engl 2012: 189, pl. 78, fig. 4.

Type material: Holotype ZIN No 62070, paratype ZIN No 62071.

Type locality: NW of Coronation Island, South Orkney islands, $60^{\circ} 12.9^{\prime} \mathrm{S}, 4^{\circ} 59^{\prime} \mathrm{W}, 5450$ 5480 m, RV Akademik Kurchatov, st. 909.

Description: Shell medium sized (to $13 \mathrm{~mm}$ ), oval-fusiform, very thin and fragile, glossy, with elevated spire and slightly attenuated siphonal canal. Protoconch of 3 whorls, first whorl (protoconch I) is smooth, brownish. Remaining whorls (Protoconch II) variably marbled in bright colours, with irregular darker spots, with indistinct, very thin spiral striation and closely spaced, arcuate axial ribs that become more irregularly spaced near the protoconch/teleoconch transition (Fig. $11 \mathrm{G}, \mathrm{H}$, arrow) that is marked by disappearance of axial ribs. Diameter $1.25 \mathrm{~mm}$, height $1.1 \mathrm{~mm}$. Teleoconch 3.5 convex whorls, separated by weakly adpressed suture. Subsutural ramp weakly concave. First half whorl of teleoconch nearly smooth, except for dense microtubercules. Axial sculpture limited to dense, irregularly spaced, slightly raised growth lines that form closely spaced arcuate axial riblets on subsutural ramp. Spiral cords narrow, distinct, slightly sinuous, covering entire shell surface, including subsutural ramp. Number of cords 1011 on penultimate and earlier whorls, $\sim 55$ on last whorl, of which 10 are on the siphonal canal. Cords vary slightly in width, interstices narrower than cords. Anal sinus shallow, subsutural, strongly asymmetrical, with deepest point just below the suture. Last whorl very high, convex, comprising 0.78 of SL. Aperture high (0.66 SL), wide, oval. Outer lip thin, evenly rounded. Parietal region with broad, extremely thin callus, overlaying spiral sculpture. Columella short ( 0.5 AL), slightly concave, with thicker, more distinct callus. Siphonal canal short, widely open, poorly differentiated from aperture. Shell color beige, with irregularly spaced axial bands and separate livid spots. Paratype very similar to holotype, but with less inflated last whorl.

Radula not studied. 


\section{$<$ TABLE 2 ABOUT HERE $>$}

Remarks: Pleurotomella tippetti is readily distinguished from Antarctic and subantarctic congeners on the basis of its nearly ovoid shell, very tall last whorl, and weakly pronounced spiral sculpture. Its protoconch is multispiral, suggesting planctotrophic development, its sculpture is similar to that of Pleurotomella packardi (Bouchet and Warén 1980: fig. 216) and, to a lesser degree, to that of $P$. maitasi. This new species differs from $P$. maitasi in lacking axial folds, and in having more rounded whorls and a different pattern of spiral sculpture. Pleurotomella tippetti superficially resembles Xanthodaphne translucida (Fig. 15 A-E) in shell outline, but differs in a having multispiral, adpressed, strongly sculptured protoconch rather than the smooth, paucispiral protoconch characteristic of X. translucida (Fig. 15D).

Distribution: In addition to the type material, the species was collected by Polarstern ANT XIX/3 (ANDEEP I) expedition on South Scotia Ridge at 2359-2380 m (Engl 2012: 189).

Etymology: The species honors the memory of the late Donn L. Tippett, M. D., an expert in the systematics of "turrids" and our good friend and colleague for many years.

\section{Subgenus Pleurotomella (Anomalotomella) Powell, 1966}

Pleurotomella (Anomalotomella) Powell 1966: 132; Dell 1990: 241.

Type species (original designation): Pleurotomella anomalapex Powell, 1951.

Diagnosis: Shell reaching $12 \mathrm{~mm}$, extremely variable, from elongate oval to fusiform and pagodiform, with short to medium high spire, large, convex, often angulated last whorl and distinct, medium to long siphonal canal. Protoconch paucispiral, up to $21 / 2$ whorls, with a finely granulose surface. Teleoconch whorls convex, in most species (except $P$. rossi and $P$. nipri) angulated at shoulder, subsutural ramp pronounced, from deeply concave to nearly straight. Anal sinus subsutural, of moderate depth, with the deepest point on subsutural ramp. Axial sculpture very variable, varices absent to strongly arcuate. Spiral sculpture variable, consisting of cords and, in some species, of strong keels. Aperture medium to high, widely ovate or ovate-pyriform.

Radula of short hypodermic marginal teeth with a large base and wide basal opening, without barb(s) at the tip.

Remarks: Twelve species occur in the Antarctic (one described herein). Of these, one also occurs in the Falkland islands.

Distribution: Antarctic and subantarctic. 
<FIGURE 12 ABOUT HERE>

\section{Pleurotomella (Anomalotomella) anomalapex Powell, 1951}

(Fig. 12 A-E)

Pleurotomella? anomalapex Powell 1951: 173, pl. VI, fig. 19.

Pleurotomella (Anomalotomella) anomalapex. - Powell 1966: 132, pl. 21, fig. 15.

Propebela anomalapex. - Castellanos and Landoni 1993: 18, pl. 1, fig. 5

Oenopota anomalapex. - Figueira and Absalão 2010: 475.

Pleurotomella species 1. - Engl 2012: 188, pl. 77, fig. 6.

Type locality: between Falkland islands and Patagonia, 50²0'S, 62³0'W, $161-162 \mathrm{~m}$ (Discovery st. WS 225).

Type material: Holotype: NHMUK 1961614, SL 7.8 mm.

Material examined: NE of Zavodovski Island, South Sandwich islands, RV Islas Orcadas, cruise 575, sta. 74, 56²12'S, 27²3'53.9"W, 179-238 m (1 sh, UNSM 887840).

Morphology: Protoconch (Fig. 12 D-E) of 2 moderately convex, evenly rounded whorls, diameter 0.9 , height $0.8 \mathrm{~mm}$, very densely sculptured by very narrow spiral striae. Protoconchteleoconch border maked by distinct nearly orthocline varix and onset of growth lines, more prominent on subsutural ramp. Animal unknown.

Remarks. This species was previously known only from the holotype. The USAP collections contain a dead collected specimen (UNSM 887840, SL $6.3 \mathrm{~mm}$ ) (Figs $12 \mathrm{~A}-\mathrm{E}$ ) that resembles the holotype, but differs in having fewer and less oblique axial ribs, as well as more rounded and more pronounced shoulder. We provisionally refer this specimen, collected NE of Zavodovski Island, South Sandwich islands to Pleurotomella anomalapex, thus greatly expanding the distribution of the species. Pleurotomella species 1, illustrated by Engl (2012: 188, pl. 77, fig. 6) from Bransfield Srait is conspecific.

This species was transferred to Propebela or Oenopota (both Mangeliidae) by Castellanos and Landoni (1993) and Figueira and Absalão (2010), respectively, although its protoconch and teleoconch are very similar to other Antarctic species of Pleurotomella.

Distribution: From the Falkland islands to the South Sandwich islands, 161-238 m.

\section{Pleurotomella (Anomalotomella) bathybia Strebel, 1908}

(Fig. 12 F)

?Pleurotomella bathybia Strebel 1908: 16, pl. 2, fig. 26 a-b. 
Pleurotomella bathybia. - Zelaya 2005: 128, fig. 53; Engl 2012: 185-186, pl. 76, fig. 2a (neotype), 2b.

Lorabela bathybia. - Powell 1966: 122; Castellanos and Landoni 1993: 21-22, pl. 2, fig. 17.

Type locality: South Georgia, 54²7.63'S, 35²41.33'W, 256 m (Polarstern, ANT XIX/5, st. 182-1) [The material on which Strebel's description was based was collected at South Georgia,

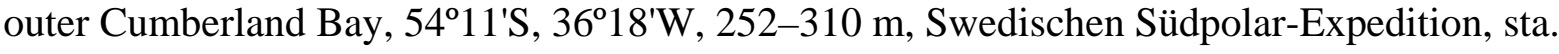
34].

Type material: Neotype (designated by Engl 2012: 186): ZSM (Mol 2002 1313), lv, SL 11 $\mathrm{mm}$.

Material examined: No material available.

Morphology: Protoconch and animal not studied.

Remarks: The holotype had been missing from SMNH for some time (Engl 2012: 186), prompting the designation of a neotype.

Distribution: South Georgia, 94-310 m (Zelaya 2005).

\section{Pleurotomella (Anomalotomella) frigida Thiele, 1912}

(fig. $12 \mathrm{G}$ )

Pleurotomella frigida Thiele 1912: 216, pl. 14, fig. 9, pl. 19, fig. 20 (radula); Powell 1958: 203; 1960: 159; Egorova 1982: 49, figs 62 (radula), 200 (based on published data only); Engl 2012: 187, pl. 77, figs 1a(lectotype)-1c.

Pleurotomella (Anomalotomella) frigida - Powell 1966: 132; Dell 1990: 243-244, figs 398, 426428; Numanami 1996: 216, figs 151A-C.

Type locality: Gauss-Station, Davis Sea, 6602'09"S, 89³8'E, 385 m.

Type material: Lectotype (designated by Engl 2012: 187): ZMB M.62982a, SL 5.2 mm, paralectotype, same locality ZMB M.62982 (juvenile).

Material examined: off Allen McDonald Glacier, Coats Land, Weddell Sea, Deep Freeze III, 75³1'S, 2643'W, 22 m (USNM 612974, 1 sh); Ross Sea, Victoria Land, RV Eltanin, cruise 32, sta. 1996, 724'58.8"S, 1728'31.2"E, 348-352 m (USNM 886147, 2 lv); Wilkes Land, Budd Coast, RV Wilkes Station, sta. AZ, 66¹6'8.92"S, 110³1'4.8"E, 128-146 m (USNM 896329, 1 lv); Ross Sea, Victoria Land, RV Eltanin, cruise 32, sta. 2005, 73²'58.8"S, 17652'1.2"E, 864870 m (USNM 898098, 1 sh).

Morphology: Protoconch (Numanami 1996: fig. 151 C) comparatively small, elevated, of $\sim 2.5$ moderately convex whorls, diameter $0.75 \mathrm{~mm}$, height $0.89 \mathrm{~mm}$, densely covered by 
microtubercules forming spiral lines. Dell (1990: fig. 426) illustrated a very similar protoconch, although without scale bar or measurements.

Radula (Thiele 1912: pl. 19, fig. 20) of simple, hypodermic marginal teeth with large base, very small, $~ 33 \mu \mathrm{m}$ in length. Although the drawing is not very detailed, the general shape the teeth is similar to those of other studied species of Pleurotomella.

Remarks: The species attains 11.4 mm (USNM 612974), more than twice the size of the lectotype.

Distribution: Davis Sea, off Enderby Land, Weddell and Ross Seas, probably circumAntarctic, 193-870 m (Powell 1960; Dell 1990; Numanami 1996), live 128-348 m.

\section{Pleurotomella (Anomalotomella) annulata Thiele, 1912}

(Fig. $12 \mathrm{H}-\mathrm{K}$ )

Pleurotomella annulata Thiele 1912: 217, pl. 14, fig. 10, 11; Egorova 1982: 49, figs 199, 206 (based on published data only); Engl 2012: 185, pl. 76, figs 1a (lectotype), 1b.

Pleurotomella (Anomalotomella) annulata. - Powell 1966: 132; Numanami 1996: 218, figs 153A-C.

Pleurotomella (Anomalotomella) cf. annulata. - Dell 199 0: 244.

Type locality: Gauss-Station, Davis Sea, 6602'09”'S, 89³8'E, in 385 m.

Type material: Lectotype (designated by Engl 2012: 185): ZMB Mol. 62981, SL 5.2 mm, two paralectotypes, ZMB (both are fragments of the shell).

Material examined: South Shetland islands, between Deception and Livingston islands, K. Halanych, sta. 59, 6248'29.9"S, 6043'30"W, 203 m (1 lv, USNM 1123584).

Morphology: Protoconch high, paucispiral, of 2 rounded whorls, diameter $\sim 0.8 \mathrm{~mm}$, height $\sim 0.92 \mathrm{~mm}$, with finely granular surface. The protoconch-teleoconch transition marked by onset of spiral sculpture. Operculum absent. Radula (Fig. $12 \mathrm{~J}-\mathrm{K}$ ) of hypodermic simple marginal teeth. Teeth small ( $~ 60 \mu \mathrm{m}$ long, 2.5\% of AL without siphonal canal), straight. Tooth canal opens laterally at tooth base, opening roughly triangular, large. Apical opening lateral, long, narrow oval. No barbs or blade. Tooth forms short, blunt spur above the basal opening (Fig. $12 \mathrm{~K}, \mathbf{s}$ ). Teeth connected to vestigial subradular membrane by wide and very thin ligament.

Distribution: Davis Sea, off Enderby Land, Ross Sea, 193-385 m (Powell 1960; Numanami 1996), live $203 \mathrm{~m}$. 


\section{Pleurotomella (Anomalotomella) deliciosa Thiele, 1912}

(Fig. 12 L-M)

Pleurotomella? deliciosa Thiele 1912: pl. 14, fig. 12.

Pleurotomella deliciosa. - Engl 2012: 186, pl. 76, fig. 3a(holotype), 3b-c.

Typhlodaphne deliciosa. - Egorova 1982: 51, fig. 211 (based on published data only).

Type locality: Gauss-Station, Davis Sea, 6602'09"S, 89³8'E, 385 m.

Type material: Holotype: ZMB (Moll 62980). SL 4 mm.

Morphology: Protoconch and radula not studied.

Material examined: Holotype.

Remarks. The holotype is a fragment $4 \mathrm{~mm}$ in length, with most of the ventral side missing (published figures show only the dorsal aspect). Engl (2012) was the first to treat this species since it's original description. He illusrated an intact, adult shell (Engl 2012: pl. 76, fig. 3c) (SL $7.5 \mathrm{~mm}$ ) that he considered to be conspecific with Pleurotomella deliciosa. It strongly resembles P. enderbyensis, as was mentioned by Engl.

Egorova (1982) placed the species in Typhlodaphne without discussion.

Distribution: Davis and Weddell seas (Engl 2012).

<FIGURE 13 ABOUT HERE>

\section{Pleurotomella (Anomalotomella) simillima Thiele, 1912}

(Fig. 13 A-D)

Pleurotomella simillima Thiele 1912: 216, pl. 14, fig. 8; Egorova 1982: 49, fig. 200 (based on published data only); Engl 2012: 188, pl. 77, Figs 5a (holotype) - 5c.

Pleurotomella (Anomalotomella) simillima Dell 1990: 241, fig. 423;

Pleurotomella similliana [sic, lapsus calami] - Hain 1990: 72, pl. 8, figs 5a, b, pl. 27, fig. 1 ;

Pleurotomella simillana [sic, lapsus calami] - Numanami 1996: 214, figs 149A-D.

Type locality: Gauss-Station, Davis Sea, 6602'09"S, 89³8'E, 385 m.

Type material: Holotype: ZMB (M.62983), SL $11 \mathrm{~mm}$.

Material examined: Scotia Sea, South Sandwich islands, SE of Visokoi Island, RV Islas Orcadas, cruise 575, sta. 61, 56²4'18"S, 270'24.1"W, 93-121 m (USNM 881740, 2 lv); Ross Sea, Victoria Land, E of Moubray Pennell Bank, RV Eltanin, cruise 32, sta. 2117, 730'S, 
17806'W, 595-600 m (USNM 898193, 1 sh); Ross Sea, Victoria Land, E of Moubray Pennell Bank, RV Eltanin, cruise 5, sta. 272, 64ํㄷ'S, 68²4'W, 412 m (USNM 898750, 1 lv); Scotia Sea, South Sandwich islands, RV Islas Orcadas, cruise 575, sta. 70, 56²4'S, 27²3'36"W; 161210 m (USNM 904646, 1 lv).

Morphology: Protoconch (Numanami 1996: Fig 149C) of 2 moderately convex whorls, diameter $1.1 \mathrm{~mm}$, height $0.92 \mathrm{~mm}$, first whorl flattened on top, protoconch translucent white in color, covered by very narrow spiral riblets. Protoconch height of holotype is $0.85 \mathrm{~mm}$, diameter $1.1 \mathrm{~mm}$ (Fig. $13 \mathrm{C})$.

Radula (Numanami 1996: Fig 149D; Hain 1990: pl 27, fig. 1) of hypodermic, simple marginal teeth. Teeth small, $\sim 100 \mu \mathrm{m}$ long (1.5\% of AL without siphonal canal), straight. Tooth canal opening at tooth base laterally, opening roughly triangular, large. Apical opening lateral, long, narrow, oval. No barbs or blade. Tooth with short, blunt spur above the basal opening. Teeth connected to vestigial subradular membrane by wide and very thin ligament.

Distribution: Davis Sea, Ross Sea, Weddell Sea, south of Kerguelen, 30-600 m (Powell 1960; Dell 1990; Numanami 1996), live 93-412 m.

\section{Pleurotomella (Anomalotomella) enderbyensis Powell, 1958}

(Fig. 13 E)

Pleurotomella enderbyensis Powell 1958: 203, pl. 2, fig. 8; Hain 1990: 71, pl. 8, fig. 4, pl. 26, fig. 8; Engl 2012: 186-187, pl. 76, fig. 5a (holotype) - 5c.

Pleurotomella (Anomalotomella) enderbyensis - Numanami 1996: 220-222, figs 155A-C.

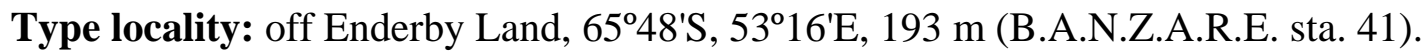
Type material: Holotype: SAM (D15512), $8.8 \mathrm{~mm}$.

Material examined: 90 miles E of Coulman Island, Victoria Land, Antarctica, Deep Freeze III, $73^{\circ} 40^{\prime} \mathrm{S}, 175^{\circ} 17^{\prime} \mathrm{W}, 521$ m (USNM 612831, $1 \mathrm{sh}$ ); S of Coulman Island, Victoria Land, Antarctica, RV Eltanin, cruise 27, sta. 1885, 74 30 'S, 170 $12^{\prime} \mathrm{W}, 311-328 \mathrm{~m}$ (USNM 870941, 1 sh); Moubray Bay, E of Cape Hallett, Victoria Land, Antarctica, RV Eltanin cruise 32, sta. 1995, $72^{\circ} 00^{\prime} \mathrm{S}, 172^{\circ} 24^{\prime} \mathrm{W}, 344-338$ m (USNM 870988, 1 sh); off Franklin Island, Victoria Land, Antarctica, RV Eltanin, cruise 51, sta. 5765, 76º7.2'S, 170²'12 W, 571-587 m (USNM 899801, 1 lv).

Morphology: Protoconch (Numanami 1996) 2.5 strongly convex whorls, diameter 1.1 $\mathrm{mm}$, height $0.98 \mathrm{~mm}$, translucent white in color, with dense microtubercules, forming irregular axial lines (Fig. 155C). Operculum absent. Radula illustrated by Hain (1990) hypodermic simple marginal teeth, very similar in shape to other studied species of the genus. 
Remarks: This species is easily distinguished from other congeners by its two broadly rounded carinae (shoulder and anterior carinae) and pronounced axial sculpture especially evident as broad knobs along the carinae. Dell (1990: 244) considered the specimens from the Ross Sea to be closely related to $P$. enderbyensis but possibly to represent a new species distinguished by a weaker anterior carina and stronger spiral sculpture. He deferred describing this form until more and better material became available.

Distribution: From off Enderby Land to the Weddell Sea and Bransfield Strait, in 188-193 m, provisionally from the Ross Sea in 311-587 m (Dell 1990; USNM material), live 275-587 m (Numanami 1996; USNM material).

\section{Pleurotomella (Anomalotomella) endeavourensis Dell, 1990}

(Fig. $13 \mathrm{~F}$ )

Pleurotomella (Anomalotomella) endeavourensis Dell 1990: 242, fig. 420 (holotype).

Pleurotomella endeavourensis. - Engl 2012: 186, pl. 76, fig. 4 (holotype).

Type locality: Ross Sea, 7607'S, 168¹0'E, 188-194 m [TAE, Trans-Antarctic (New Zealand) Expedition, st. 98]

Type material: Holotype: NMNZ (M.256622), SL 10.9 mm (Fig. 12 E); paratype NZ Oceanographic Institute (P.755).

Material examined: No additional material available.

Morphology: Protoconch (Dell 1990: 242) of slightly less than 2 whorls, sculptured with fine spiral threads crossed by fine axial riblets, forming a varix at transition to teleoconch. Operculum and radula unknown.

Remarks: This species is known only from the type material.

Distribution: Ross Sea, in 188-377 m (Dell 1990), live 188-194 m.

\section{Pleurotomella (Anomalotomella) rossi Dell, 1990}

(Fig. $13 \mathrm{G})$

Pleurotomella (Anomalotomella) rossi Dell 1990: 243, figs 424, 425, 429.

Pleurotomella rossi. - Engl 2012: 187, pl. 77, fig. 4 (holotype).

Type locality: Ross Sea, 77050'S, $166^{\circ} 30$ 'E, 369 m [New Zealand Oceanographic Institute, st. A470]

Type material: Holotype: NIWA (\# 276), SL 11.9 mm, paratypes - NIWA (P.756, according to Dell 1990), NMNZ (M.256623). 
Material examined: Ross Sea, Victoria Land, Moubray Bay, E of Cape Hallett, RV Eltanin, cruise 32, sta. 1995, 720'S, 172²3'E, 344-348 m (USNM 886122, 1 sh).

Morphology: Protoconch (Dell 1990: fig. 425) conical, of 2.5 moderately convex whorls, diameter $1.17 \mathrm{~mm}$, height $1.01 \mathrm{~mm}$, very densely sculptured by microtubercules, arranged in irregular spiral striae.

The animal is unknown.

Distribution: Ross Sea, 133-377 m (Dell 1990).

\section{Pleurotomella (Anomalotomella) innocentia (Dell, 1990), n. comb.}

(Fig. $13 \mathrm{H}-\mathrm{L}$ )

Typhlodaphne innocentia Dell 1990: 240-241, Figs 394, 406; Engl 2012: 178, pl. 72, fig. 4. not Typhlodaphne innocentia sensu Aldea and Troncoso 2008 [= Falsimohnia minor (Strebel, 1908) - Kantor and Harasewych 2013: 51].

Type locality: Ross Sea, $72^{\circ} 00^{\prime} \mathrm{S}, 172^{\circ} 28^{\prime} \mathrm{E}, 530-549 \mathrm{~m}$ (RV Eltanin, st. 1997).

Type material: Holotype: USNM 860147, SL 4.2 mm, paratype NMNZ (M.256621), SL $3.7 \mathrm{~mm}$.

Material examined: holotype; Ross Sea, Victoria Land, RV Eltanin, cruise 32, sta. 1996, 724'48"S, 1728' 24"E, 348-352 m (1 lv, USNM 886157).

Morphology: Protoconch (holotype, Fig. 13 K-L) high, obtusely conical, of 1.75 convex whorls, diameter $0.67 \mathrm{~mm}$, height $0.6 \mathrm{~mm}$, smooth, except last half whorl, which bears inconspicuous axial riblets. Protoconch-teleoconch transition marked with orthocline varix and appearance of sinuous growth lines.

Remarks: Dell (1990: 241) attributed his new species to Typhlodaphne without discussion and compared Typhlodaphne innocentia not to T. purissima, the type species of the genus, but with two species that are now attributed to Xanthodaphne (Raphitomidae), namely $X$. corpulenta and $X$. translucida. Dell treated Typhlodaphne very broadly and included many unrelated species in this genus (see above). Nevertheless, the described species is much smaller that Xanthodaphne and is conchologically similar to other species attributed here to Pleurotomella (Anomalotomella), especially to $P$. frigida, which has a wider shell with more pronounced spiral sculpture. It has little in common with Typhlodaphne purissima and there are no conspicuous reasons to retain it in that genus. Pending data on radular morphology, we transfer this species to Pleurotomella. 
The record of Aldea and Troncoso (2008) of this species from the Bellingshausen Sea is based on a specimen of Falsimohnia minor (Strebel, 1908) (Kantor, Harasewych 2013).

Distribution: Ross Sea, 348-549 m, live 348-352 m.

\section{Pleurotomella (Anomalotomella) nipri (Numanami, 1996), n. comb.}

(Fig. 14 A-C)

Typhlodaphne nipri Numanami 1996: 212-213, figs 148 A-C; Engl 2012: 178, pl. 72, fig. 5.

Type locality: Breid Bay, Queen Maud Land, Antarctica, 7009.0'S, 23ํ⒍3'E, 275-283 m.

Type material: Holotype: NSMT Mo70633, SL 3.1 mm, 2 paratypes NSMT Mo70634, 70635.

Material examined: No material available.

Morphology: Protoconch (Numanami 1996: fig. 148C) not large, of $~ 2$ convex whorls, diameter $0.88 \mathrm{~mm}$, height $0.66 \mathrm{~mm}$, pale yellow in color. The surface is covered with microtubercules, more dense on second whorl, where they are arranged in spiral lines.

The animal is unknown.

Remarks: Numanami (1996: 213) attributed this species to Typhlodaphne on the basis of its resemblance to Typhlodaphne innocentia Dell, 1990 and also compared it with Pleurotomella frigida, but not with the type species of the Typhlodaphne, T. purissima.

"Typhlodaphne" nipri bears no resemblance to T. purissima or T. paratenoceras, being much smaller (up to $5.3 \mathrm{~mm}$ versus nearly $50 \mathrm{~mm}$ in $T$. paratenoceras), with a nearly oval shell outline rather than the narrow, fusiform outline of Typhlodaphne. The shell outline and protoconch of "Typhlodaphne" nipri is more similar to species of Pleurotomella (Anomalotomella), particularly to $P$. innocentia and $P$. frigida, differing primarily in having a smooth shell. Pending data on radular morphology, we transfer this species to Pleurotomella.

This species is presently known only from the material examined by Numanami. It is very similar to "Typhlodaphne species", illustrated by Engl (2012: pl. 72, fig. 6a-b). If they prove to be conspecific, then the distibution of P. nipri would be extended to the Weddell Sea.

Distribution: Off Breid Bay, Queen Maud Land, Antarctica, 270-289 m, live 276-289 m (Numanami 1996). 
(Fig. 14 D-L)

Type locality: Antarctica, between Deception and Livingston islands, K. Halanych, sta. 59, 6248'29.88"S, 6043'30"W, 203 m.

Type material: Holotype, USNM 1123582, paratype, USNM 1123581.

Description: Shell (Figs 14 D-E) small (to $5.7 \mathrm{~mm}$ ), very thin, fusiform/ pagodiform, with low (spire angle $76-79^{\circ}$ ), stepped spire and concave sutural ramp with posteriorly deflected carina along its periphery. Protoconch (Fig. 14 I) tall $(900 \mu \mathrm{m})$, conical, increasing in diameter from $\approx 225$ to $930 \mu \mathrm{m}$ in 2 evenly rounded whorls, with fine granules arranged in spiral rows. Transition to teleoconch distinct, marked by the appearance of sinuate axial grown lines, a strong shoulder, and 2 spiral cords below the shoulder. Teleoconch of up to 3 sharply shouldered, convex whorls. Suture adpressed, subsutural area sloping to posteriorly deflected, thickened carina at shoulder. Spiral sculpture of low spiral cords with narrower interstices, 7 weak cords between suture and shoulder, 45 cords between shoulder and siphonal canal, 15 cords on siphonal canal that are slightly wider than on shell periphery. Axial sculpture limited to fine prosocline growth lines that are strongly sinous between shoulder and suture (corresponding to anal sinus). Last whorl high, $\approx 0.76$ of SL. Anal sinus wide, deep ( $\sim 1 / 8$ whorl). Aperture large $(\mathrm{AL} / \mathrm{SL}=0.46)$, wide $(\mathrm{AL} / \mathrm{AW}=1.8)$, oval, deflected from coiling axis by $28^{\circ}$, with broad, convex parietal region, short, weakly sinuous columella, and long, wide, open, axial siphonal canal. Outer lip thin, fragile, smooth. Shell color yellowish white, with darker, caramel colored bands along shoulder and between shell periphery and distal siphonal canal. Entire teleoconch surface is finely granulose. Operculum absent. Radula of holotype (Fig. $14 \mathrm{~J}-\mathrm{L}$ ) with simple, hypodermic marginal teeth. Teeth small, $50 \mu \mathrm{m}$ long (1.7\% of AL and 1.1\% of SL), straight.

Tooth canal opening laterally at tooth base, opening roughly triangular, large. Apical opening lateral, long, narrow, oval. No barbs or blade. Tooth with short, blunt spur above the basal opening (Fig. $14 \mathrm{~K}, \mathbf{s}$ ). Teeth connected to vestigial subradular membrane by wide and very thin ligament.

\section{<TABLE 3 ABOUT HERE>}

Remarks. Pleurotomella petiti may be easily distinguished from all congeners by its characteristic pagodiform shell with a sharply angled shoulder and posteriorly deflected carina. It somewhat resembles $P$. annulata, which has a laterally directed carina at the shoulder, as well as an anterior carina, and multiple raised spiral cords between the suture and shoulder and along the last whorl that are absent in $P$. petiti.

Etymology: The species is named in the memory of the late Richard E. (Dick) Petit, expert in the systematics of the Cancellariidae as well as the history and literature of malacology, and our good friend for many years. 


\section{Genus Xanthodaphne Powell, 1942}

Xanthodaphne Powell 1942: 166. Type species (by original designation): Pleurotoma (Thesbia) membranacea Watson, 1886; Recent, New Zealand (North Island).

Diagnosis: Shell medium sized, attaining $24 \mathrm{~mm}$, ovate to widely ovate, with low to medium high spire, high last whorl and short, medium to wide siphonal canal. Protoconch large, either paucispiral, bulbous, and smooth or very finely striated, or multispiral, reticulated. Teleoconch whorls evenly convex or slightly angulated at shoulder, subsutural ramp variously pronounced, in most species very weak, nearly straight. Anal sinus subsutural, deep, with deepest point on subsutural ramp. Axial sculpture limited to growth lines, some raised, producing the appearance of very narrow axial ribs. Spiral sculpture of narrow, dense spiral cords. Aperture high, wide, ovate.

Operculum absent.

Radula of short conic hypodermic marginal teeth with very wide basal opening and lacking barb at the tip.

Distribution: North and tropical Atlantic, Tropical Pacific, subantarctic, Antarctic, from sublittoral to abyssal depths.

Remarks: Thirty-one species are currently recognized in the genus Xanthodaphne (Gofas 2015), mostly from temperate and tropical waters. Only three species, including one described below, are currently known from within the Antarctic Convergence.

The genus Xanthodaphne was originally established by Powell (1942: 166) to include two deep-water New Zealand species, Pleurotoma (Thesbia) membranacea Watson, 1886 and $P$. (Th.) xanthias Watson, 1886. Later Powell (1966: 129) added a single species, Xanthodaphne maoria Dell, 1956. The genus has gradually expanded to contain a total of 31 Recent species, mostly from deep-water, including species with both planctotrophic and non-planctotrophic development. Xanthodaphne is poorly defined conchologically, and radular morphology remains unknown for most species. As currently understood, this genus is likely paraphyletic.

\section{<FIGURE 15 ABOUT HERE>}

\section{Xanthodaphne translucida (Watson, 1881)}

(Fig. 15 A-E)

Pleurotoma (Thesbia) translucida Watson 1881: 444; 1886: 330, pl. 25, fig. 11.

Typhlodaphne translucida. - Powell 1951: 175; Dell 1990: 239-240. 
Xanthodaphne translucida - Numanami 1996: 222-224, figs 157A-E, 158; Engl 2012: 189, pl. 78, fig. 2a-b.

Type locality: Challenger, stns. 145, between Marion Island and Prince Edward Island, 46²3'S, $38^{\circ 04}$ '30”E, 256 m; 149b, Royal Sound, Kerguelen Island, 49²8'S, 70³0'E, 46 m; 149 d, Royal Sound, Kerguelen Island, 49²8'S, 70¹3'E, $51 \mathrm{~m}$.

Type material: Syntypes (Figs 15 A-E): NHMUK 1187.2.9.1041-5, st. 145 (3 syntypes), st. $149 b$ (1 syntype), 149d (1 syntype).

Material examined: type material.

Morphology: Protoconch paucispiral (Fig. 15 D), 2.5 whorls, obtuse, conical, nearly smooth. Diameter (syntype) $1.12 \mathrm{~mm}$, height $0.9 \mathrm{~mm}$ (Numanami 1996: fig. 157, diameter 1.2, height $0.8 \mathrm{~mm}$ ).

Radula (Numanami 1996: fig. 157 D-E), of very short hypodermic, loosely enrolled marginal teeth. Length $\sim 55 \mu \mathrm{m}(0.75 \%$ of $\mathrm{AL})$, conic, unbarbed, with very wide basal opening of tooth canal spanning 1/2 of tooth length, and long slit-like apical opening, spanning 1/5 of tooth length. At the level of upper part of basal opening there is a small outgrowth, probably homologous to a spur. Teeth have a well developed ligament.

Operculum absent.

Remarks: Pleurotoma (Thesbia) translucida was attributed to the genus Typhlodaphne Powell, 1951 (type species Bela purissima Strebel, 1908) by Powell (1951: 175). However, the type species of Typhlodaphne has an operculum, and belongs to the family Borsoniidae based on the morphology of its foregut and radula. Numamani (1996: 224) provisionally transferred this species to Xanthodaphne on the basis of its shell and radular morphology and lack of operculum.

The radula of this species, which consists of short, simplified, marginal hypodermic teeth, clearly indicates its position within Raphitomidae, while the shell of X. translucida closely resembles that of $X$. membranacea (Watson, 1886), the type species of Xanthodaphne.

Distribution: Marion Island, 99-113 m, Kerguelen Island, 20-168 m, off the Crozet islands (115-205 m), Enderby Land, Antarctic continent between $49^{\circ} \mathrm{E}-53^{\circ} \mathrm{E}, 193-300 \mathrm{~m}$ (Powell 1960; Dell 1990), live 275-289 m (Numanami 1996).

Xanthodaphne raineri (Engl, 2008), n. comb.

(Fig. 15 F-J)

Pleurotomella raineri Engl 2008b: 58-59, figs 3-4; Engl 2012: 187, pl. 77 fig. 3a-b. 
Type locality: west of Antarctic Peninsula, Bellinshausen Sea (Pacific Antarctic Basin), from $62^{\circ} 31.37^{\prime} \mathrm{S}-64^{\circ} 40.20^{\prime} \mathrm{W}$ to $62^{\circ} 31.33^{\prime} \mathrm{S}-64^{\circ} 40.52^{\prime} \mathrm{W}, 3798-3799 \mathrm{~m}$, Polarstern ATN 22/3 (AN-DEEP III) Exp., sta. 154-7.

Type material: Holotype: ZSM Mol 2005 0880, SL 6 mm.

Material examined: IORAS, Davis Sea, RV Ob', st. 285, 59²9'S, 9706.7' E, 4540 m (1 lv).

Morphology: Protoconch consists of $\sim 2.5$ whorls, height $\sim 0.95 \mathrm{~mm}$, diameter $1.25 \mathrm{~mm}$; it is brownish, partly eroded, so microsculpture is not discernible (Engl 2008). First whorl adpressed, upper 1 1/2 protoconch whorls light brownish, darker than the renaining protoconch and teleoconch whorls.

Anatomy of single available specimen (shell Fig. 15 F-G) was examined. Head with moderately long cylindrical tentacles (Fig. $15 \mathrm{~J}$, ct), eyes absent. Penis very short but stout, with small antero-lateral papilla situated in a depression of the right wall of the proboscis.

Rhynchostome with large sphincter (Fig. 15 J, rhsp) and probably short contracted funnel. Proboscis (Fig. $15 \mathrm{~J}$, pr), short, cylindrical, strongly contracted, with telescoping folds. Venom gland moderately long, muscular bulb (Fig. $15 \mathrm{~J}, \mathrm{mb}$ ), comparatively very large, longer than proboscis. Radula sac short, radula consists of $\sim 25$ rows of teeth.

Radula (Fig. 15 I) of simple, hypodermic, marginal teeth. Teeth small, $140 \mu \mathrm{m}$ long (1.4\% of AL without siphonal canal), straight. Tooth canal opening at tooth base laterally, opening large, oval. Apical opening lateral, long, narrow, oval. No barbs or blade. Tooth forming short, blunt spur above the basal opening (Fig. 15 I, s). Teeth connected to vestigial subradular membrane by wide and very thin ligament.

Remarks. Pleurotomella raineri was described from a juvenile specimen with a shell of about two teleoconch whorls and a broken lip, obscuring its shape. Based on comparisons of the partially broken protoconch, upper teleoconch whorl sculpture, as well as the shape of the anal sinus, we consider a single specimen, collected by the Russian RV Ob' in the Davis Sea at 4540 $\mathrm{m}$ to be conspecific with Pleurotomella raineri. This specimen differs considerably from the type in size (32.5 mm versus $6 \mathrm{~mm}$ ). The protoconch of this specimen (Fig. $15 \mathrm{H}$ ) is eroded, with a height of $0.9 \mathrm{~mm}$, diameter $1.2 \mathrm{~mm}$, but agrees well with Engl's (2012:187) description, especially with regard to the lack of microsculpture (with only inconspicuous axial ribs visible with oblique light).

The shape and size of adult shell requires a reconsideration of the generic position of Pleurotomella raineri. The next largest Antarctic Pleurotomella, P. maitasi, attains a length of $14.5 \mathrm{~mm}$, less than half the length of the specimen from the Davis Sea. As currently understood, 
Xanthodaphne includes species with moderately developed spiral sculpture and a pronounced subsutural ramp. Therefore we provisionally transfer Pleurotomella raineri to Xanthodaphne.

Distribution: Bellinshausen and ?Davis Sea, live 3,800-4,540 m.

\section{Xanthodaphne pastorinoi n. sp.}

(Fig. 16)

\section{Type material: holotype, USNM 881383.}

Type locality: Candlemas Island, South Sandwich islands, Scotia Sea; 56 58'42”S, 26³0'36”W, 1,651-1,684 m, RV Islas Orcadas, cruise 575, st. 37.

Description: Shell medium sized (to $23 \mathrm{~mm}$ ), fusiform, very thin, fragile, glossy, with elevated spire and slightly attenuated siphonal canal. Protoconch eroded, nucleus missing. Remaining portion of protoconch consists $\sim 2$ whorls, diameter $950 \mu \mathrm{m}$. Protoconch/teleoconch transition marked by onset of spiral sculpture. Teleoconch of 7 convex whorls. Suture weakly adpressed. Subsutural ramp very weakly convex, nearly flat. Axial sculpture limited to irregularly spaced, slightly raised growth lines, some forming closely spaced, arcuate axial riblets along subsutural ramp, $~ 50$ on penultimate whorl. Spiral cords narrow, distinct, absent on subsutural ramp, covering remaining portions of shell. Number of cords increases from five on first teleoconch whorl to 20 on penultimate whorl and 65 on last whorl, of which 10 are on the siphonal canal. Cords vary in width, interstices narrower than cords. Anal sinus deep, subsutural, nearly symmetrical, with deepest point along middle of subsutural ramp. Last whorl convex, high (0.68 of SL). Aperture high (0.55 of SL), wide, oval, with thin, evenly rounded outer lip. Parietal region with broad, extremely thin callus overlaying spiral sculpture. Columella short ( 0.33 AL), with thicker, more distinct callus. Siphonal fold present, distinct. Siphonal canal short, widely open, poorly differentiated from aperture. Shell chalky white.

Measurements: SL 23.0 mm, BWL 15.9 mm, AL 12.9 mm, SW 10.3 mm.

Soft tissues of the holotype were rehydrated. Body lacks pigmentation. Head well defined, with long, likely distendable snout. Cephalic tentacles long, cylindrical, rounded distally. Eyes absent. Foot long, narrow, with broad propodium. Operculum absent. Proboscis of moderate length, straight, with contracted walls, basal region surrounded by septum with wide orifice. Venom gland and muscular bulb large. Radula comprised of short, hypodermic, loosely enrolled marginal teeth. Length $\sim 140 \mu \mathrm{m}(0.93 \%$ of AL), elongate-conic, unbarbed. Basal opening of tooth canal broad, nearly terminal, apical opening long slit-like, spanning $~ 1 / 5$ of tooth length. Base of the tooth with poorly pronounced spur (Fig. 16 D, arrow). Teeth with well developed ligament. 
Remarks: Although this new species is presently known only from the holotype, it is readily distinguished from Xanthodaphne translucida, the only other Antarctic species on the basis of protoconch and shell morphology.

Xanthodaphne pastorinoi belongs in the family Raphitomidae, as is confirmed by absence of an operculum, and by the characteristic shape of the head and radula. It is far larger than Xanthodaphne translucida (23.0 mm vs $14.1 \mathrm{~mm}$ for the largest known specimen of $X$. translucida) and has a more elongated shell with a much lower last whorl, more distinct spiral cords, and arcuate axial riblets on the subsutural ramp. Radular teeth are very similar in both species.

Distribution: Known only from the type locality.

Etymology: This new species honors Dr. Roberto Guido Pastorino, Senior Researcher at the Museo Argentino de Ciencias Naturales "Bernardino Rivadavia", a colleague and colaborator for many years, in recognition for his numerous contributions to studies of Antarctic and subantarctic molluscan faunas.

\section{<FIGURE 16 ABOUT HERE>}

\section{Family COCHLESPIRIDAE Powell, 1942}

\section{Genus Aforia Dall, 1889}

Mangilia (Aforia) Dall 1889: 99. Type species (original designation): Pleurotoma circinata Dall, 1873; Recent, North Pacific (Unalaska, Alaska).

Steiraxis Dall 1896: 14. Type species (original designation): Pleurotoma (Steiraxis) aulaca Dall, 1895; Recent, off Acapulco, Mexico.

Irenosyrinx Dall 1908: 257. Type species (original designation): Pleurotoma (Leucosyrinx) goodei Dall, 1890; Recent off NW coast of Patagonia.

Aforia (Dallaforia) Sysoev and Kantor 1987: 115 Type species (original designation): Irenosyrinx? crebristriata Dall, 1908; Recent, off Sitka, Alaska.

Aforia (Abyssaforia) Sysoev and Kantor 1987: 117. Type species (original designation): Aforia (Abyssaforia) abyssalis Sysoev \& Kantor, 1987; Recent, off Kurile islands. 
Diagnosis: Shell large to very large, attaining $97 \mathrm{~mm}$, elongate-fusiform, with high spire, and long siphonal canal. Protoconch almost always decollated, smooth, paucispiral or multispiral when preserved. Teleoconch whorls moderately to strongly convex, in some species angulated at shoulder. Subsutural ramp pronounced to varying degrees, from shallowly concave to convex. Anal sinus deep, with rounded apex and deepest point on lower portion of subsutural ramp. Axial sculpture limited to growth lines. Spiral sculpture of spiral cords varying in strength, some species with one or two keels. Aperture moderately high, ovate.

Operculum present, oval, with terminal nucleus distinctly turned to left, in A. goodei (Dall, 1890) nucleus subcentral, situated in lower part of operculum.

Radula consists of a wide, crescent-shaped, unicuspid central tooth and duplex lateral teeth, with a pointed obtuse major limb and a large accessory limb of similar length.

Remarks: As presently understood, Aforia is a very widely distributed genus, ranging from the upper boreal waters of the Pacific and Atlantic Oceans to the Southern Ocean surrounding Antarctica. Twenty species have been included in the genus primarily on the basis of shell morphology, and, in some cases, radular characters. Sysoev and Kantor (1987) recognized the complex structure of the genus and described two new subgenera, based on the pattern of spiral sculpture. Dell (1990) disputed the validity of these subgenera, noting that at least some of the Antarctic species could not be attributed to any recognized subgenus on the basis of spiral sculpture. We follow the opinion of Dell and do not recognize subgenera.

The broad, nearly bipolar distribution of Aforia had not been previously corraborated by molecular data. Our analysis using COI sequences from two Antarcic species as well as the recently descibed Aforia serranoi Gofas, Kantor \& Luque (2014) from bathyal depths off the Iberian Peninsula, in addition to some closely related Cochlespiridae demonstrates that the three species of Aforia constitute a well supported clade (posterior probability value $=1$ ), indicating a close relationship among geographically distant species (Fig. 17).

Distribution: Atlantic, north and tropical eastern Pacific, subantarctic and Antarctic, at bathyal to abyssal depths.

\section{<FIGURE 17 ABOUT HERE>}

\section{Aforia goniodes (Watson, 1881)}

(Fig. 18 A-E)

Pleurotoma clara von Martens 1880: 35, pl. 8, fig. 1 (non Pleurotroma clara Reeve, 1845). 
Pleurotoma (Surcula) goniodes Watson 1881: 394; 1886: 291, pl. 20, fig. 4 (fig. 5 in text lapsus calami).

Aforia goniodes. — Engl 2012: 179. pl. 73, fig. 1.

Aforia gonioides (sic). - Dell 1990: 234, figs 402, 403.

Type locality: south-east of Rio de la Plata, Argentina, $37^{\circ} 17^{\prime} \mathrm{S}-52^{\circ} 52^{\prime} \mathrm{W}, 1,097 \mathrm{~m}$.

Type material: Lectotype NHMUK (1887.2.9.970), SL 22.9 mm (Fig. 18 A-B). Neither in the original description (1881), nor in the Report on the Scientific Results of the Voyage of H.M.S. Challenger (1886) did Watson mention how many specimens of this species he had examined. Dell (1995: 234) referred to the specimen as "holotype", a valid lectotype designation before 2000 (Article 74.6 of ICZN (1999)).

Material examined: type specimen; Scotia Sea, Falkland islands, Beauchene Island, RV Eltanin, cruise 6, sta. 339, 536'0"'S, 59³0'0"W, 512-586 m (USNM 870139, 1 sh); Scotia Sea, Falkland islands, Beauchene Island, RV Eltanin, cruise 6, sta. 340, 536'0"S, 59³0'0"W, 567578 m (USNM 870155, 1 sh); Scotia Sea, Falkland islands, Beauchene Island, RV Eltanin, cruise 6, sta. 340, 536'0"S, 59²3'59"W, 567-578 m (USNM 870158, 3 sh); South Shetland islands, Bransfield Strait, South of Penguin Island, RV Eltanin, cruise 6, sta. 428, 6242'0"S, 57²4'59"W, 662-1120 m (USNM 870295, 1 sh); Scotia Sea, NE of East Falkland Island, RV Eltanin, cruise 7, sta. 557, 5153'59"S, 56³6'0"W, 855-866 m (USNM 870341, 1 sh); Scotia Sea, Falkland islands, Beauchene Island, RV Eltanin, cruise 6, sta. 340, 536' ${ }^{\prime} 0^{\prime \prime S}, 59^{\circ} 30^{\prime} 0^{\prime \prime} \mathrm{W}$, 567-578 m (USNM 881883, 4 lv); Scotia Sea, Drake Passage, RV Eltanin, cruise 6, sta. 399, 59²'12"S, 56 6'0" W (USNM 881889, 1 lv); Drake Passage, E of Cape Cape Horn, RV Eltanin, cruise 9, sta. 740, 56 ${ }^{\circ} 6^{\prime} 0^{\prime \prime S}, 6^{\circ} 24^{\prime} 0^{\prime \prime} \mathrm{W}, 384-494$ m (USNM 898860, 1 sh); Argentina, 54²8'47.99"S, 62¹2'36"W, 318 m (USNM 1123638, 1 lv); Argentina, 54²2'48"S, 6152'48"W, 274 m (USNM 1123679, 1 lv).

Morphology: Protoconch paucispiral, bulbous, of $\sim 2$ smooth rounded whorls, diameter $1.3 \mathrm{~mm}$, height $1.2 \mathrm{~mm}$, protoconch/teleoconch transition is marked by appearance of sutural keel. Operculum oval-triangular, with terminal nucleus.

Radula (Fig. 18 E) short, consisting of 22 transverse rows of teeth, 7-8 nascent. Central tooth wide crescent-shaped, with indistinct anterior border gradually fusing into subradular membrane. Posterior margin slightly thickened, with short obtuse central cusp. Lateral tooth length $\sim 250 \mu \mathrm{m}(2.7 \%$ of aperture length without siphonal canal), duplex, with pointed major limb with sharp edges, and large accessory limb of same length.

Remarks. Engl (2012: 179) expressed doubt that this species ocurs in Antarctic waters. Dell (1990, figs 402, 403) illustrated two specimens from the South Shetland islands (Eltanin, st. 
428, USNM 870295). Another specimen, USNM 881889, was collected in the Scotia Sea north of Elephant Island.

Distribution: This species ranges from off Argentina southward throughout the Magellanic Province to South Shetland islands, at depths of $150 \mathrm{~m}$ to $1120 \mathrm{~m}$, live 274-578 m.

\section{<FIGURE 18 ABOUT HERE>}

\section{Aforia watsoni nom. nov.}

(Figs 18 F-I)

Pleurotoma (Surcula) lepta Watson 1881: 391; 1886: 288, pl. 18, fig. 7 (non Pleurotoma lepta Edwards 1861: 244, pl. 28, figs 10a-c. Stubbington and Bracklesham Bay, Eocene). Aforia lepta. - Sysoev and Kantor 1987: 107, figs 1F, G, 5B, 6E-H, 8A-E; Dell 1990: 234, fig. 404.

Type locality: Southern Ocean, southwest of Australia, Challenger st. 157, 5355'S, $108^{\circ} 35^{\prime} \mathrm{E}, 3,566 \mathrm{~m}$.

Type material: Holotype: NHMUK 1889.11.11.7, SL 40.6 mm (Fig. 18 F-G).

Material examined: Southwest Pacific Basin, RV Eltanin, cruise 11, sta. 913, 6547'59"S, 11500'W, 4773 m (USNM 881947, 1 lv); Antarctic Ocean, Marie Byrd Land, RV Eltanin,

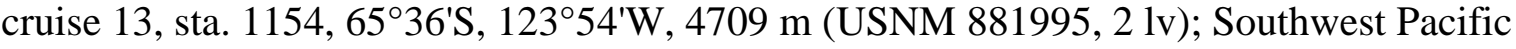
Basin, NE of Ross Sea, RV Eltanin, cruise 20, sta. 134, 5947'59"S, 14448'W, 3200-3259 m (USNM 896401, 1 lv); Antarctic Peninsula, Graham Land, NE of Joinville Island, RV Eltanin, cruise 12, sta. 1003, 6240'47.99"S, 5443'1.19"W, 210-220 m (USNM 896402, 3 lv); Antarctic Peninsula, Graham Land, NE of Joinville Island, RV Eltanin, cruise 12, sta. 1003, 6240'47.99"S, 54²3'1.19"W, 210-220 m (USNM 898513, 1 sh); Antarctic Ocean, RV Eltanin, cruise 23, sta. 1668, 6354'S, 108²4'W, 4930-4963 m (USNM 1114797, 1 lv).

Morphology: Protoconch eroded in all examined specimens. Operculum pale yellow, thin, oval, with terminal nucleus, shifted to the left.

Radula not examined.

Remarks: The homonymy of Pleurotoma (Surcula) lepta Watson, 1881 and Pleurotoma lepta Edwards, 1861 was first recognized by Tucker (2004: 554), but no replacement name had been proposed.

Distribution: From southwest Australia and New Zealand, to Kerguelen Island, the Weddell Sea and the Antarctic Peninsula (Dell 1990; Sysoev and Kantor 1987; USNM collections), live 220-4963 m. 
Etymology: The new name honors Rev. Robert Boog Watson (1823-1910), the author of Challenger report on Scaphopoda and Gastropoda.

\section{Aforia magnifica (Strebel, 1908)}

(Fig. 19 A-I)

?Surcula magnifica Strebel 1908: 19, pl. 3, fig. 32 a-d.

Aforia magnifica. - Powell 1951: 167, fig. M 91 (radula); Dell 1990: 231, figs 411, 412, 436;

Hain 1990: 69, pl. 7, figs 8a-c (shell), pl. 26, figs 1,2 (radula); Castellanos and Landoni 1993: 5, pl. 3, fig. 28; Engl 2012: 179, pl. 73, figs 2a (lectotype), 2 b.

Danilacarina elenae Bozzetti 1997: 43, fig. 1.

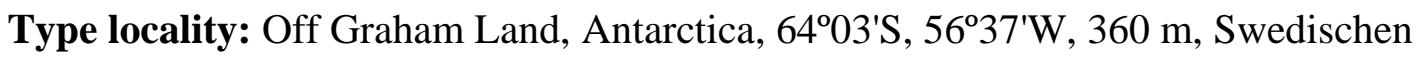
Südpolar-Expedition, sta. 8.

Type material: Lectotype: SMNH Type-1328 (designated by Engl 2012: 179), SL 63.0 mm. Paralectotypes- SMNH Type-6172, st. 8 (SL 54.9 mm, siphonal canal broken); SMNH Type- 6304, SW of Snow Hill Island, 64³6'S, 57²42'W, 120 m, Swedischen SüdpolarExpedition, sta. 6 (fragment of dead collected shell).

Material examined: Palmer Peninsula, E of Hugo Island, RV Polar Duke, 656'S, 6554'W, 150 m (USNM 846186, 3 sh); South Shetland islands, N of Livingston Island, RV

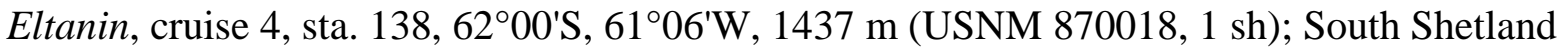
islands, W of Elephant Island, RV Eltanin, cruise 6, sta. 410, 61 ${ }^{\circ} 18^{\prime} \mathrm{S}, 5^{\circ} 06^{\prime} \mathrm{W}, 220-240 \mathrm{~m}$ (USNM 870244, 1 sh); South Sandwich islands, Zavodovski Island, RV Islas Orcadas, cruise 575, sta. 73, 56¹6'12"S, 2730'W, 208-375 m (USNM 894456, 4 sh); Antarctic Peninsula, Bransfield Strait, RV Hero, cruise 833, sta. 21-1, 63²3'24"S, 570'35.6"W, 276-280 m (USNM 897616, 4 lv); Ross Sea, Victoria Land, Moubray Pennell Bank, RV Eltanin, cruise 32, sta. 2119, 7306'S, 18000" E, 567 m (USNM 898196, 1 sh); Antarctic Peninsula, RV Eltanin, cruise 12, sta. 1003, 6240'58.8"S, 5443'1.2" W, 210-220 m (USNM 898899, 1 sh); Antarctica, K. Halanych, sta. 21, 6309'S, 57²'12"W, 146-192 m (USNM 1121894, 1 lv); Antarctica, Trinity Peninsula, K. Halanych, sta. 51, 63²2'48"S, 60³'36"W, 277 m (USNM 1121899, 1 lv); Bellingshausen Sea, off Antarctic Peninsula, K. Halanych, sta. 52, 65³9' 36"S, 68²'24"W, 282 m (USNM 1121900, 1 lv); Bellingshausen Sea, off Antarctic Peninsula, K. Halanych, sta. 82, 65³9'36"S, 68¹'48"W, 278 m (USNM 1121904, 1 lv); South Shetland islands, Elephant Island, Bransfield Strait, K. Halanych, sta. 38, 6245'S, 56²45'W, 207 m (USNM 1121906, 1 lv); between Deception and Livingston islands, K. Halanych, sta. 59, 6248'36"S, 6043'48"W, 203 m (USNM 11219076, 1 lv). 


\section{<FIGURE 19 ABOUT HERE>}

Morphology: Protoconch erroded in most studied adults, in lectotype (Fig. 19 C) it is tall, $\sim 2$ convex whorls (the protoconch/teleoconch border is indistinct due to erosion), $\sim 1.9 \mathrm{~mm}$ in height and $1.8 \mathrm{~mm}$ in diameter. Operculum spanning 2/3 of aperture length, elongate oval, with terminal nucleus, turned to left.

Radula (Figs $19 \mathrm{H}-\mathrm{I}$ ) consists of 56 transverse rows of teeth, 15 nascent. Central tooth wide, crescent-shaped, with indistinct anterior border gradually fusing into subradular membrane. Posterior margin slightly thickened, distinct long, sharp central cusp emanates from anterior margin of tooth base. Lateral tooth length $\sim 440 \mu \mathrm{m}(2.9 \%$ of aperture length without siphonal canal), duplex, with pointed obtuse major limb (Fig. 19 H, ml) with sharp edges, and large accessory limb (Fig. $19 \mathrm{H}$, al) of nearly the same length.

Remarks: Wiese (2001) regarded Danilacarina elenae, described from Kerguelen Island, to be a synonym of $A$. multispiralis Dell, 1990 . However, we consider it to be more similar to $A$. magnifica and transfer the name into synonymy of this species.

The radula of this species was first reported by Hain (1990: pl. 26, figs 1-2) and is similar in all details to our observations.

Two specimens were sequenced, from different localities along the Antarctic Peninsula. The COI sequence of a third specimen downloaded from GenBank was more closely related to the geographically more proximal specimen (USNM 1121894) than to the specimen (USNM 1121900) from a more remote locality, suggesting the presence of geographical genetic variation (Fig. 17).

Distribution: Antarctic Peninsula, South Shetlands, South Orkneys and the South Sandwich islands (92-1455 m), from the Antarctic continent between $62^{\circ} \mathrm{E}$ and $74^{\circ} \mathrm{E}(177-437$ m) and from the Ross Sea (567-1890 m) (Dell 1990), live 146-280 m.

\section{Aforia multispiralis Dell, 1990}

(Fig. $19 \mathrm{~J}-\mathrm{L}$ )

Aforia multispiralis Dell 1990: 231, 233, figs 413, 414, 416, 433, 435; Engl 2012: 180, pl. 73, figs 3a-c.

Type locality: off South Shetland islands, 62²7'S, 5758'W, 1116-809 m (Eltanin, sta. 426). 
Type material: Holotype: USNM 860145, SL $57.0 \mathrm{~mm}$, paratype in the NMNZ (M.256641).

Material examined: Holotype; South Sandwich islands, SE of Visokoi Island, RV Islas Orcadas, cruise 575, sta. 67, 56²44'35.88"S, 27²'42"W, 137-155 m (USNM 896288, 2 lv); South Shetland islands, RV Eltanin, cruise 4, sta. 138, 62²'31.2"S, 618'31.2"W, $1437 \mathrm{~m}$ (USNM 870023, 1 sh); South Shetland islands, Nelson Island, RV Eltanin, cruise 6, sta. 432, 6253'31.2"S, 59²1'W, 884-935 m (USNM 870304, 3 sh); South Orkney islands, RV Eltanin, cruise 12, sta. 1084, 60²2'30"S, 4651'0"W, 298-403 m (USNM 870645, 2 sh); South Shetland islands, Penguin Island, RV Eltanin, cruise 6, sta. 428, 6240'1.2"S, 57²4'28.8"W, 662-1120 m (USNM 881913, 1 lv); South Shetland islands, Nelson Island, RV Eltanin, cruise 6, sta. 432, 6253'31.2"S, 59²1'W, 884-935 m (USNM 881916, 1 sh); Antarctic Peninsula, RV Eltanin, cruise 12, sta. 1002, 6240'1.2"S, 5444'31.2"W, 265 m (USNM 881973, 2 lv); South Shetland islands, Bransfield Strait, Gibbs Island, RV Eltanin, cruise 12, sta. 997, 615'S, 5555'1.2"W, 769 m (USNM 898635, 1 sh).

Morphology: Protoconch of "two rather bulbous whorls, smooth" (Dell 1990: 233). Operculum, not studied. Radula not examined.

Remarks. Engl (2012) pointed out the difficulties in assigning some specimens either to $A$. magnifica or A. multispiralis. The major difference, according to Dell (1990) is the presence of two sharp keels or carinae on upper teleoconch whorls in A. multispiralis "instead of the single rounded carina" in A. magnifica. In A magnifica, the suture is adpressed onto the more rounded anterior carina, while in A. multispiralis, the suture is adpressed below the sharply keeled anterior carina.

Distribution: Antarctic Peninsula, Bransfield Strait, South Shetlands, South Orkneys, 1371455 m (Dell 1990; USNM material), live 137-1120 m.

\section{Aforia hedleyi (Dell, 1990), comb. nov.}

(Fig. 20)

Pontiothauma? hedleyi Dell 1990: 245, figs 396, 417.

Type locality: Ross Sea, $76^{\circ} \mathrm{S}, 165^{\circ} 6^{\prime} \mathrm{W}, 494-498 \mathrm{~m}$ (RV Eltanin, sta. 2097)

Type material: Holotype: USNM 860148, SL 58.0 mm, paratypes USNM 860149, SL 97.1 mm, NMNZ M.256640.

Material examined: Holotype; Ross Sea, RV Eltanin, cruise 32, sta. 2045, 760'28.8"S, 176²4' 1.2"E, 566-569 m (USNM 860149, 1 sh, paratype); Ross Sea, Victoria Land, Moubray 
Pennell Bank, RV Eltanin, cruise 32, sta. 2039, 7600'S, 17206'E, 565-569 m (USNM 896145, 1 lv); Ross Sea, Victoria Land, Moubray Pennell Bank, RV Eltanin, cruise 27, sta. 1933, 73²4'S, 177²42'E, 465-474 m (USNM 898517, 2 sh); Adélie Land, RV Aurora Australis, cruise Ceamarc, sta. 87EV524, 6529'S, 139¹9'E, 414 m (MNHN IM-2009-8188, 1 lv, sequenced).

\section{<FIGURE 20 ABOUT HERE>}

Morphology: Protoconch (Dell 1990: 245) "rather flat-topped, dome-shaped, of 1 1/2 whorls." Operculum was not available for the sudy. Radula (Fig. 20 E-F) long, $5.8 \mathrm{~mm}$ in length (14\% of aperture length without siphonal canal), consists of $\sim 80$ transverse rows of teeth, of which $\sim 15$ are nascent. Central tooth wide crescent-shaped, with indistinct anterior border gradually fusing into subradular membrane. Posterior margin slightly thickened, distinct, with long, sharp central cusp emanating from mid region of tooth base. Lateral teeth $\sim 460 \mu \mathrm{m}$ in length (1.1\% of aperture length without siphonal canal), duplex, with pointed obtuse major limb with sharp edges, and large accessory limb 2/3 of major limb length.

Remark: The species was described on the basis on empty shells and compared to "Pontiothauma" ergata Hedley, 1916. The holotype (Fig. 20 A) is an immature specimen (slightly over half the maximum known size for this species) and with a very angulated shell base. The paratype (Fig. 20 B-C) (not previously illustrated) shows the morphology of an adult specimen.

A large specimen (with broken base and siphonal canal) (Fig. 20 D) was recently collected off Adelie Coast in $414 \mathrm{~m}$, and was available to anatomical and molecular studies. It is similar to the paratype in size, and to the holotype of $A$. hedleyi in surface sculpture. Its radular morphology and COI sequence (Fig. 17) show clear affinities with Aforia.

Aforia hedleyi differs from all other Antarctic species of the genus in lacking a pronounced angulation or keel on the shoulder.

Distribution: Ross Sea and Adelie Coast, 315-574 m, live 414 m.

\section{Family PSEUDOMELATOMIDAE Morrison, 1965}

\section{Conorbela Powell, 1951}

Conorbela Powell 1951: 170. Type species (by original designation): Bela antarctica Strebel, 1908; Recent, Antarctica. 
Diagnosis: Shell large, attaining $29 \mathrm{~mm}$, ovate-biconic, with moderately high spire, and short and wide siphonal canal. Protoconch eroded in studied specimens, presumably paucispiral. Teleoconch whorls convex, angulated at shoulder, subsutural ramp shallowly concave, nearly straight. Anal sinus very wide and shallow, occupying subsutural ramp. Axial sculpture limited to growth lines and irregular low folds. Spiral sculpture of dense and narrow spiral cords, cord along shoulder may be more pronounced and thickened to form a keel. Aperture high, widely ovate.

Operculum present, small, oval-triangular, with terminal nucleus.

Radula consists of duplex lateral teeth, with pointed sharp major limb and large accessory limb.

Remarks: This genus is monotypic. Powell (1966) attributed this genus to Mangeliinae and did not find a radula. The radula was first illustrated by Dell (1990: fig. 434) as a line drawing, roughly depicting a duplex marginal tooth, which precludes inclusion of the genus in Mangeliidae. Hain (1990: pl. 26, figs 3, 4) published a SEM photo of a similar radula. This genus was questionably attributed to Pseudomelatomidae by Bouchet et al. (2011) on the basis of radular morphology. A single specimen (USNM 1121892, Fig. $21 \mathrm{E}$ ) was sequenced for COI. A Bayesian analysis of a dataset that included a number of species representing different families of Conoidea with similar radular type, including several Pseudomelatomidae, did not reveal a well supported sister group. The position of Conorbela may possibly be clarified by using a multigene approach. Presently we follow Bouchet et al. (2011) and retain it in Pseudomelatomidae.

Distribution: South Shetland islands, along both sides of the Antarctic Peninsula, in the Weddell, Bellingshausen and Ross Seas.

<FIGURE 21 ABOUT HERE>

\section{Conorbela antarctica (Strebel, 1908)}

(Fig. 21)

Bela antarctica Strebel 1908: 16-17, pl. 3, fig. 30 a-b.

Conorbela antarctica. - Powell 1951: 170; Carcelles 1953: 198; Powell 1960: 159; Powell 1966: 122, pl. 19, fig. 15; Dell 1990: 239, figs 395, 415, 434 (radula); Hain 1990: 70, pl. 7, figs 9a, b, pl. 26, figs 3, 4 (radula); Engl 2012: 183-184, pl. 75, fig. 1a-b (syntype, labelled as holotype), c. 
Type locality: SW of Snow Hill Island, 64³6'S, 57²42'W, 120 m, Swedischen SüdpolarExpedition, sta. 6; Shag Rock Bank, 53³4'S, 43²3'W, 160 m, Swedischen Südpolar-Expedition, sta. 17.

Type material: 2 syntypes, the illustrated syntype from st. 6 (SMNH Type-1062), SL 28.9 mm, and broken specimen from st. 17 (SMNH Type-6302). Only the single specimen from st. 6 was mentioned in the original description. The second shell is so damaged, that its conspecifity can not be confirmed (A. Warén, personal communication).

Engl (2012) erroneously considered one of the syntypes (Fig. 21 A-B) to be the holotype of this species, probably because Strebel (1908) only mentioned this single specimen in the original description. We designate here the syntype from st. 6 as lectotype (SMNH Type-1062).

Material examined: Type material; South Shetland islands, N of Livingston Island, RV Eltanin, cruise 4, sta. $138,62^{\circ} 00^{\prime} \mathrm{S}, 61^{\circ} 6^{\prime} \mathrm{W}, 1437$ m (USNM 870021, 1 sh); Antarctic Peninsula, Graham Land, NE of Joinville Island, RV Eltanin, cruise 12, sta. 1002, 62 $42^{\prime} \mathrm{S}, 5^{\circ} 42^{\prime} \mathrm{W}, 265 \mathrm{~m}$ (USNM 870558, 1 sh); Antarctic Peninsula, Graham Land, NE of Joinville Island, RV Eltanin, cruise 12, sta. $1003,62^{\circ} 42^{\prime} \mathrm{S}, 54^{\circ} 42^{\prime} \mathrm{W}, 210-220$ m (USNM 870607, 1 sh); South Shetland

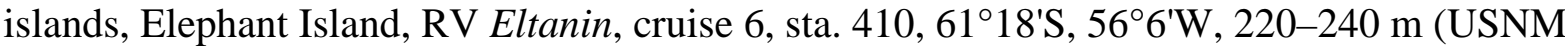
881895, 2 lv); South Shetland islands, Bransfield Strait, Penguin Island, RV Eltanin, cruise 6, sta. 426, 62³0'S, 580'W, 808-1116 m (USNM 881909, $1 \mathrm{lv}$ ); South Orkney islands, SE of Laurie Island, RV Islas Orcadas, cruise 876, sta. 823, 61¹9'47.9"S, 44²6'24"W, 274-280 m (USNM 894432, 1 sh); South Sandwich islands, Zavodovski Island, RV Islas Orcadas, cruise 575, sta. 73, 56¹6'12"S, 27³0'W, 208-375 m (USNM 894465, 3 lv); South Shetland islands, Elephant Island, Bransfield Strait, K. Halanych, sta. 38, 6245'S, 5645'W, 207 m (USNM 1121892, 1 lv, sequenced); South Shetland islands, Elephant Island, Bransfield Strait, K. Halanych, sta. 38, 62 $45^{\prime}$ S, 56²45'W, 207 m (USNM 1121959, 1 lv).

Morphology: The protoconch and upper teleoconch whorls are erroded in all available specimens. Operculum (Fig. 21 C) medium sized, spanning 1/3 of aperture length, triangular in lower part and rounded in upper part, with terminal nucleus. Radula (Fig. 21 D) of duplex marginal teeth along weak subradular membrane. Central teeth absent. Marginal teeth small, $160 \mu \mathrm{m}$ long ( 1\% of AL), with sharp, flattened major limb with a triangular tip and large, slightly curved accessory limb, spanning 2/3 of tooth length, narrow in middle part and broadening at a base.

Remarks. The monotypical genus Conorbela is the only representative of the family Pseudomelatomidae in Antarctic waters.

Distribution: Scotia Sea, Antarctic Peninsula, Bransfield Strait, South Shetland islands, Ross Sea, 68-1437 m (Dell 1990). 


\section{Family HORAICLAVIDAE Bouchet, Kantor, Sysoev \& Puillandre, 2011}

\section{Micropleurotoma Thiele, 1929}

Micropleurotoma Thiele 1929: 362. Type species (by original designation): Pleurotoma spirotropoides Thiele, 1925; Recent, Agulhas Bank off South Africa.

Diagnosis: Shell small, attaining $9.2 \mathrm{~mm}$, elongate, turriform, with high spire, and moderately long, attenuated siphonal canal. Protoconch smooth, paucispiral, globose, $\sim 2$ whorls. Teleoconch whorls convex, angulated or carinated at shoulder, subsutural ramp from shallowly concave to nearly straight. Anal sinus moderately deep, apex on peripheral cord. Axial sculpture limited to growth lines or low folds, forming knobs along shoulder. Spiral sculpture of indistinct threads or absent. Aperture low, elongate, oval with angulated outer lip.

Operculum present, small, oval, with terminal nucleus.

Radula consists of duplex lateral teeth, with pointed, sharp major limb and small accessory limb.

Remarks: Four species are currently recognized within Micropleurotoma. This genus was questionably attributed to Pseudomelatomidae by Bouchet et al. (2011) on the basis of radular morphology.

Distribution: North Atlantic to South Africa (type species) and Antarctica, all at bathyal depths.

<FIGURE 22 ABOUT HERE>

\section{Micropleurotoma remota (Powell, 1958)}

(Fig. 22 A-D)

Spirotropis remota Powell 1958: 204, pl. 2, fig. 5.

Micropleurotoma remota. - Numanami 1996: 205-206, fig. 142 A-D; Engl 2012: 180, pl. 73, fig. 4 a-b.

Type locality: off Enderby Land, $66^{\circ} 10^{\prime}$ S, $49^{\circ} 41^{\prime} E, 300$ m (B.A.N.Z.A.R.E. sta. 39).

Type material: Holotype: SAM (D 15513), SL 7.7 mm.

Material examined: South Shetland islands, RV Eltanin, cruise 4, sta. 129, 6146'58.8"S, 61³0'W, 3678-3816 m (USNM 896502, 1 lv); South Atlantic Ocean, between Falklands and 
South Georgia Island, RV Eltanin, cruise 7, sta. 552, 5259'31.20"S, 4853'31.2"W, 2928-3084 m (USNM 1187809, 1 lv).

Morphology: Protoconch (Numanami 1996: 205, fig. 142C) "somewhat glossy white in color, large and roundly inflated, about 2 in number of turns, $1.3 \mathrm{~mm}$ in length, $1.0 \mathrm{~mm}$ in diameter, with a smooth surface". Operculum (Numanami 1996: 206) "small to the aperture in size, and length occupies about $45 \%$ of aperture length and width about $65 \%$ of aperture width, corneous, thin, translucent pale yellow in color, ovate with downward by situated nuculeus." Radula (Fig. $22 \mathrm{C}-\mathrm{D})$ rather long $(0.67 \mathrm{~mm}$, or 0.21 of $\mathrm{AL})$, narrow $(65 \mu \mathrm{m}$, or $2 \%$ of $\mathrm{AL})$, of around 50 rows of teeth (4-5 nascent), consists of duplex marginal teeth. Marginal teeth with long and narrow major limb with sharp tip and edges and small accessory limb, spanning about $2 / 3$ of tooth length (around $50 \mu \mathrm{m}$, or $1.5 \%$ of AL).

Remarks: the species was transferred to Micropleurotoma by Numanami (1996) on the basis of its radular morphology. The radula of the type species, $M$. spirotropoides (Thiele, 1925) was illustrated by Bouchet and Warén (1980: fig. 4), who also extended the range of species, originally described from the Agulhas Bank off South Africa, into the North Atlantic. It is generally similar to that of $M$. remota. The shell of $M$. spirotropoides (Fig. 22 E-G) differs from that of $M$. remota in having a shorter spire and in lacking axial ribs. The radula is typical for Horaiclavidae, but lacks characters diagnostic at the generic level. We retain the position of this species in Micropleurotoma as there are not other genera that can better accommodate it.

Distribution: off Enderby Land, in 193-955 m (Numanami 1996), Weddell Sea, in 26003405 m (Engl 2012) and Scotia Sea (USNM 1187809) live 2928-3816 m.

Family TURRIDAE H. \& A. Adams, 1853

Genus unknown

\section{"Lophiotoma" pseudoannulata Dell, 1990}

(Fig. 22 H-L)

Lophiotoma pseudoannulata Dell 1990: 235-236, figs 392 (shell), 432 (radula); Engl 2012: 189, pl. 78, fig. 3a-b.

Type locality: Ross Sea, $72.5^{\circ} \mathrm{S}, 177.1^{\circ} \mathrm{E}, 1883 \mathrm{~m}$ (Eltanin, sta. 2121)

Type material: Holotype: USNM 860146, SL 19.0 mm; two paratypes in NMNZ (M.256620, M.261121). 
Material examined: Holotype; Ross Sea, RV Eltanin, cruise 32, sta. 2081, 7555'12"S, 173¹6'48"W, 476 m (1 sh, USNM 898177).

Morphology: Protoconch "of two smooth, bulbous whorls with a few brephic axial riblets towards the close of the last whorl" (Dell 1990: 235). Operculum "brown, oval, with a flattened base, and latero-terminal nucleus" (Dell 1990: 235). Dell (1990: 235, fig. 432) reported that the radula consists of short duplex marginal teeth and narrow, broad-based, delicate central teeth with a relatively small median cusp (not illustrated in his drawing).

Remarks. The species is known only from the type material and an additional specimen from the Ross Sea.

The taxonomic position of the species is unclear. Radular morphology, as well as the general shell shape and position of the anal sinus indicates that the species belongs in the family Turridae. Dell (1990:236) stated that "generic placement in Lophiotoma can only be provisional". Indeed, the shell of "L." pseudoannulata differs greatly from any Lophiotoma in shape and sculpture. The radula of Lophiotoma lacks the central tooth and the marginal teeth are much longer and slender. The radula, as illustrated and described is more similar to that of the genus Turris Batsch, 1789 (see SEM of the radula of Turris crispa (Lamarck, 1816) (Bouchet et al. 2011: fig. 21 F). Nevertheless there are no conchological similarities between "L." pseudoannulata and any Turris species. The only genus of Turridae dwelling in high latitudes of the Southern Hemisphere is the genus Ptychosyrinx Thiele, 1925, which is characterized by very strong axial folds along the shell periphery. Although there is not currently an appropriate genus within Turridae to incorporate "Lophiotoma" pseudoannulata, we abstain from describing a new monotypic genus due to the lack of adequate material.

Distribution: Ross Sea, 205-1890 m (Dell 1990), live 213 m.

\section{INSERTAE SEDIS}

\section{“Leucosyrinx” macrobertsoni Powell, 1958}

(Fig. $22 \mathrm{M}$ )

Leucosyrinx macrobertsoni Powell 1958: 202, pl. 3, fig. 5; Engl 2012: 184, pl. 75, fig. 3.

Type locality: Off MacRobertson Land, 6645'S, 6203'E, 177 m (B.A.N.Z.A.R.E. sta. 107).

Holotype: SAM (D 15510), SL $42.6 \mathrm{~mm}$.

Material examined: no material available.

Distribution: Known only from the type locality. 
Remarks. The species is known only from the dead-collected holotype. The subsutural position of anal sinus is somewhat similar to Antarctospira, but the shell shape (with very tall multiwhorled spire, low aperture with short siphonal canal) precludes its inclusion in the latter genus. Without examination of the radula neither generic, nor even familial position can be clarified.

\section{ANTARCTIC SPECIES REMOVED FROM CONOIDEA}

\section{Bela anderssoni Strebel, 1908}

Bela anderssoni Strebel 1908: 14-15, pl. 2, fig. 24 a-d; Melvill and Standen 1912: 355; Powell 1951: 56; Engl 2012: 180-181, pl. 73, fig. 6b.

Falsimohnia anderssoni. - Kantor and Harasewych 2013: 52, figs 39-41.

Type locality: SE of Seymour Island, 64²0'S, 56 38'W, 150 m, Swedischen SüdpolarExpedition, sta. 5.

Type material: Holotype: SMNH Type-1063.

Remarks: Transferred to Falsimohnia Powell, 1951 (Buccinulidae) (Kantor and Harasewych 2013: 52).

Distribution: SE of Seymour Island and Elephant Island, South Shetland islands, 150-240 m.

\section{Bela anderssoni var. minor Strebel, 1908}

Bela anderssoni var. minor? Strebel 1908: 15; Powell 1951: 59; Engl 2012: 181, pl. 73, fig. 6 . Falsimohnia minor. - Kantor and Harasewych 2013: 51, figs 28-34.

Type locality: South Georgia, outer Cumberland Bay, 54²11'S, 36²18'W, 252-310 m, Swedischen Südpolar-Expedition, sta. 34.

Type material: three syntypes, SMNH Type- 1057.

Remarks: Transferred to Falsimohnia Powell, 1951 (Buccinulidae) as Falsimohnia minor (Kantor and Harasewych 2013: 51).

Distribution: South Georgia, Bellinghausen Sea, Peter I Island, 90-310 m.

\section{Bela fulvicans Strebel, 1908}

Bela fulvicans Strebel 1908: 15, pl. 2, fig. 25 a-d; Melvill and Standen 1912: 356; Powell 1951: 56, 59; Zelaya 2005: 128, fig. 52 (figure erroneously labeled as Lorabela pelseneeri); Engl 2012: 181, pl. 73, fig. 7a-c. 
Falsimohnia fulvicans. - Kantor and Harasewych 2013: 48, figs 21-27, 35-36.

Type locality: South Georgia, Cumberland Bay, outside Grytviken, 54 22'S, 36 27'W, 24 52 m (Swedish South Polar Expedition, sta. 25).

Type material: Lectotype, SMNH Type 6303 (designated by Engl 2012: p. 181).

Paralectotypes: SMNH Type 1030 (st. 34, Cumberland Bay, 54¹1'S, 360180'W, 252-310 m);

SMNH Type 6159 (st. 95, off Astrolabe Island, 6409'S, 58²17'W, 95 m)

Remarks: Transferred to Falsimohnia Powell, 1951 (Buccinulidae) (Kantor and Harasewych 2013: 48).

Distribution: South Georgia, and questionably Burwood Bank, 95-310 m.

\section{Bela notophila Strebel, 1908}

Bela notophila Strebel 1908: 20-21, pl. 2, fig. 28 a-d; Engl 2012: 181, pl. 73, fig. 5.

Strebela notophila. - Kantor and Harasewych 2013: 53, figs 37-38, 44-45.

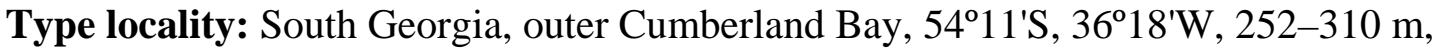
Swedischen Südpolar-Expedition, sta. 34,

Type Material: Holotype, SMNH Type-1064

Remarks: The new, monotypical genus Strebela Kantor \& Harasewych, 2013

(Buccinulidae) was erected to include this species (Kantor and Harasewych 2013: 53).

Distribution: South Georgia, 97-310 m.

Insertae sedis

Pleurotoma tcherniai Gaillard, 1955

Gaillard 1955: 682-683, fig. 1.

Type locality: Adelie Land, 10-100 m.

Type Material: Holotype MNHN IM-2000-0241 (photo available online at http://science.mnhn.fr/institution/mnhn/collection/im/item/2000-0241), SL 5.5 mm.

Remarks: The holotype is the only known specimen and is a badly broken shell. The taxonomic position is unclear and it may represent a species of Buccinoidea.

Distribution: Known only from the type locality.

\section{DISCUSSION}

\section{Rich or poor?}


The fauna of Conoidea within the Antarctic convergence includes 42 recognized species and subspecies attributed to 14 genera and subgenera (two being unnamed or undetermined) in at least seven families (Table 4).

\section{<TABLE 4 ABOUT HERE>}

Raphitomidae is richest in species (17 species), with Pleurotomella s.l. being the most diverse genus (14 species). It is followed by Borsoniidae (10 species, four genera). The majority of genera, incorporating 33 species, are characterized by radulae consisting of hypodermic marginal teeth (for more details see Kantor and Puillandre 2012) (families Mangeliidae, Raphitomidae and Borsoniidae), while the genera with radula of non-hypodermic, duplex marginal teeth (families Cochlespiridae, Pseudomelatomidae, Horaiclavidae, and Turridae) are mostly represented by single species, except for Aforia, which includes five Antarctic species. This is similar to the ratio in Arctic waters of Russia, where only one out of approximately 40 species possesses a radula with non-hypodermic marginal teeth [Spirotropis monterosatoi (Locard, 1897), Drilliidae]. Only two Antarctic genera (including one undescribed genus incorporating "Lophiotoma" pseudoannulata) are monotypic (15\% of genera).

At a first glance the total number of "turrids" in Antarctic waters seems low, considering the wide bathymetric (30-5700 m) and geographic range, especially when compared to conoidean diversity in the tropical realm. For example, at the Koumac site in New Caledonia, which was extensively sampled mostly at shallow depths (down to $10 \mathrm{~m}$ ), "turrids" (and Conoidea in general) were the most diverse group of the Neogastropoda, and were represented by 263 morphospecies, more than $48 \%$ of total number of Neogastropoda species.

Comparisons of "turrid" species richness with other well studied faunas revealed a similar relative abundance of "turrids" (Table 5). The low number of "turrid" species in Antarctic waters is indicative of the general impoverishment of gastropod fauna in Antarctica, as well as of possible undersampling of gastropods in difficult hydrological conditions and the absence of mollusks in the uppermost bathymetric zone.

\section{<TABLE 5 ABOUT HERE>}

\section{Endemism}

Only two genera (Lorabela and monotypical Conorbela) can be considered as endemic to waters within the Antarctic convergence. Another four (Antarctospira, Typhlodaphne, Belalora, and Pleurotomella (Anomalotomella)) occur in both Antarctic and subantarctic waters. Six other 
genera have broad geographic distributions. The genus that includes "Lophiotoma" pseudoanulata is not included, nor is "Leucosyrinx".

Comparisons of Conoidea to another diverse group of Antarctic Neogastropoda, Buccinoidea, reveals that Buccinoidea are characterized by a higher rate of endemism and a larger proportion of monotypical genera. Out of 18 genera (including one subgenus) of Buccinoidea found within the Antarctic convergence, 11 (61\%) are endemic to Antarctic waters, six extend only slightly beyond the Antarctic convergence ( Kerguelen and Crozets islands) and only a single genus (Meteuthria Thiele, 1912) occurs both within the convergence and in the Magellanic region (data from Harasewych and Kantor 2004; Kantor and Harasewych 2013). Among Buccinoidea found within the convergence, nine genera (50\%) are monotypic, while only two genera of Conoidea are monotypic.

Buccinoidea are characterized by direct development, undergoing the larval stages within the egg capsules, and emerging as crawling young. However, the broad distribution of some conoidean genera recorded in Antarctica does not correlate with mode of larval development. Among broadly distributed genera only Pleurotomella s.s. possess a multispiral protoconch that is indicative of planctotrophic larval development. In contrast, Xanthodaphne and Aforia, which has a very broad distribution that spans the North Pacific and North Atlantic Oceans (as confirmed by molecular data), have paucispiral protoconchs, suggesting intracapsular development. Most of Antarctic conoidean species have non-planctotrophic protoconchs.

At the species level the rate of endemism of turrids in Antarctica is much higher $-82 \%$ of species are endemic to Antarctica. Only three species, Pleurotomella anomalapex, Aforia goniodes, and Aforia watsoni extend well beyond the limits of the convergence into the Magellanic Province, Argentina and even southwestern Australia. One species, Xanthodaphne translucida extends to Marion Island and the Crozets. In comparison, all the species of Buccinoidea that occur in Antarctic waters are endemic to Antarctica.

\section{Bathymetric distribution}

All genera of Conoidea (except "Leucosyrinx" macrobertsoni) inhabiting Antarctica waters extend into bathyal depths, and five continue into the abyssal zone (Table 4, Fig. 23). Rather remarkable is the very broad bathymetric range of genera, as well as of some species. Nine species occuring in the upper bathyal zone have a bathymetric range of more than $1000 \mathrm{~m}$, while Typhlodaphne purissima (94-2855 m), Aforia watsoni (220-4963 m), Micropleurotoma remota (193-3084 m) had ranges of $2500 \mathrm{~m}$ or more. It should be noted, that we were not able to 
examine all the specimens on which these records were based and erroneous identifications and even the existence of species complexes with different bathymetric ranges are quite possible.

\section{<FIGURE 23 ABOUT HERE>}

Greatest species diversity occurred at depths between 100 and $400 \mathrm{~m}$ with the number of species gradually diminishing down to $2800 \mathrm{~m}$ with slight increase in the number of species at depths of 3000-5000 m (Fig. 24).

$<$ FIGURE 24 ABOUT HERE $>$ 


\section{Acknowledgements}

This publication resulted from several visiting curatorships of YIK to USNM supported by the USAP grants. YIK is greatly indebted to the staff of the Department of Invertebrate Zoology of USNM, especially to Paul Greenhall and Chad Walter for assistance and arranging loans. We want to thank Dr. Mathias Glaubrecht from Museum für Naturkunde, Berlin for the loan of Thiele's type specimens) and to Andrea Salvador from NHMUK for help with the types of R. B. Watson and A.W.B. Powell. Dr. Alexander Fedosov from A.N.Severtzov Institute of Ecology and Evolution kindly photographed some of the types in NHMUK, N.N. Surovenkova from the same institute assisted in photographing radulae on the SEM.

Drs A. Gebruk and E. Krylova kindly provided access to the material collected by Russian research vessels in Antarctica, which is stored in IORAS.

This work is partially financed by the Grant of RFBR No. 14-04-00481 (PI Yu.I. Kantor), by the Service de Systématique Moléculaire (UMS 2700 CNRS-MNHN) and by the project CONOTAX, funded by the French ANR (grant number ANR-13-JSV7-0013-01). The authors also thank Barbara Buge, Julien Brisset and Laetitia Aznar-Cormano for their help in curating the specimens.

The CAML-CEAMARC cruises of RSV Aurora Australis and TRV Umitaka Maru (IPY project $n^{\circ 53}$ ) were supported by the Australian Antarctic Division, the Japanese Science Foundation, the French polar institute IPEV (ICOTA and REVOLTA programs), the CNRS, the MNHN and the ANR (White Project ANTFLOCKs USAR n07-BLAN-0213-01 directed by Guillaume Lecointre). 
Aldea, C., Olabarria, C. \& Troncoso, J.S. (2008) Bathymetric zonation and diversity gradient of gastropods and bivalves in west Antarctica from the South Shetland islands to the Bellinghausen Sea. Deep-Sea Research Part 1 Oceanographic Research Papers 55, 350365. DOI:10.1016/j.dsr.2007.12.002

Aldea, C. \& Troncoso, J.S. (2008) Systematics and distribution of shelled mollusks (Gastropoda, Bivalvia and Scaphopoda) from the South Shetland islands to the Bellingshausen Sea, West Antarctica. Iberus 26, 43-117.

Barnard K. H. (1963) Deep sea Mollusca from west of Cape Point, South Africa. Annals of the South African Museum, 46, 407-452.

Belkin, I. M. \& Gordon, A. L. (1996) Southern Ocean fronts from the Greenwich meridian to Tasmania. Journal of Geophysical Research 101, 3675-3696.

Beu, A.G. (2011) Marine Mollusca of isotope stages of the last 2 million years in New Zealand. Part 4. Gastropoda (Ptenoglossa, Neogastropoda, Heterobranchia). Journal of the Royal Society of New Zealand, 41, 1-153. DOI: 10.1080/03036758.2011.548763

Bogdanov, I. P. (1987) [An integrated study of the taxonomic features of the marine gastropods of the subfamily Oenopotinae subfam. nov.]. Vsesoiuznoe soveshchanie po izucheniiu molliuskov [Leningrad] 8, 35-37 (in Russian).

Bogdanov, I.P. (1990) Molluscs of Oenopotinae subfamily (Gastropoda, Pectinibranchia, Turridae) in the seas of USSR. Fauna of USSR, Mollusks 5(3): 1-221 (in Russian).

Bouchet, P., \& Kantor, Yu. I. (2004) New Caledonia: the major center of biodiversity for volutomitrid mollusks (Mollusca: Neogastropoda: Volutomitridae). Systematics and Biodiversity, 1: 467-502. DOI: http://dx.doi.org/10.1017/S1477200003001282

Bouchet, P., Kantor, Yu. I., Sysoev, A. \& Puillandre, N. (2011) New operational classification of the Conoidea (Gastropoda). Journal of Molluscan Studies 77, 273-308. DOI 10.1093/mollus/eyr017

Bouchet P., Lozouet, P., Maestrati, P. \& Heros, V. (2002) Assessing the magnitude of species richness in tropical marine environments: high numbers of molluscs at a New Caledonia site. Biological Journal of the Linnean Society 75: 421-436. DOI: 10.1046/j.10958312.2002.00052.x

Bouchet, P., Lozouet, P. \& Sysoev, A.V. (2009) An inordinate fondness for turrids. Deep-Sea Research 56, 1724-1731. DOI: 10.1016/j.dsr2.2009.05.033 
Bouchet, P. \& Warén, A. (1980) Revison of the north-east Atlantic bathyal and abyssal Turridae. Journal of Molluscan Studies, Supplement 8, 1-119.

DOI:10.1093/mollus/46.Supplement_8.1

Bozzetti, L. (1997) Descrizione di un nuovo genere ed una nuova specie (Gastropoda: Turridae, Turriculinae) dalle Isole Kerguelen, Oceano Indiano meridionale. World Shells 23, 42-44. Carcelles, A. (1944) Nota sobre algunos moluscos magallánicos obtenidos frente al Río de la Plata. Comunicaciones Zoológicas del Museo de Historia Natural de Montevideo 1(19), 111.

Carcelles, A. (1953) Catalogo de la malacofauna Antarctica Argentina. Anales del Museo Nahuel Huapí 3, 155-250, 4 pls.

Castellanos, Z.J.A. \& Landoni, N. (1993) Catálogo descriptivo de la malacofauna magallánica, 11. Neogastropoda Turridae. Comisión de Investigaciones Cientificas, Provincia de Buenos Aires, Argentina.

Dall, W.H. (1889) Reports on the results of dredging, under the supervision of Alexander Agassiz, in the Gulf of Mexico (1877-78) and in the Caribbean Sea (1879-80), by the U.S. Coast Survey steamer "Blake," Lieut.-Commander CD. Sigsbee, U.S.N., and Commander J.R. Bartlett, U.S.N., commanding. XXIX. Report on the Mollusca. Part 2, Gastropoda and Scaphopoda. Bulletin of the Museum of Comparative Zoology 18: 1-492, pls. 10-40.

Dall, W.H. (1896) Diagnoses of new species of mollusks from the west coast of America. Proceedings of the U.S. National Museum 18: 7-20.

Dall, W.H. (1908) Reports on the dredging operations off the west coast of Central America to the Galapagos, to the west coast of Mexico, and in the Gulf of California, in charge of Alexander Agassiz, carried on by the U.S. Fish Commission steamer "Albatross," during 1891, Lieut.-Commander Z.L. Tanner, U.S.N., commanding. XXXVII. Reports on the scientific results of the expedition to the eastern tropical Pacific, in charge of Alexander Agassiz. by the U.S. Fish Commission steamer "Albatross," from October, 1904. to March, 1905, Lieut.-Commander L.M. Garrett, U.S.N., commanding. XIV. The Mollusca and Brachiopoda. Bulletin of the Museum of Comparative Zoology 43: 205-487, pl. 1-22.

Dell, R.K. (1990) Antarctic Mollusca with special reference to the fauna of the Ross Sea.

Bulletin of the Royal Society of New Zealand, 27, 1-311.

Edwards, F.E. (1861) A monograph of the Eocene Mollusca, or descriptions of shells from the older tertiaries of England. Part III, No. III. Prosobranchiata (continued) 12.

Palaeontographical Society, London, pp. 241-330, pls. 28-33.

Egorova, E. (1982) Biological results of the Soviet Antarctic expeditions, 7. Molluscs of the Davis Sea. Explorations of the Fauna of the Seas. 26(34), pp. 1-142 (in Russian). 
Engl, W. (2008a) Antarctic mollusks, part 10: Oenopota weirichi n. sp., the first bathyal-abyssal Oenopota from the Antarctic (Mollusca, Gastropoda: Turridae). Club Conchylia Informationen 39, 49-53.

Engl, W. (2008b) Antarctic molluscs, part 11: Pleurotomella maitasi n. sp. and P. raineri n. sp., two new abyssal turrids from the Antarctic (Mollusca, Gastropoda: Turridae). Club Conchylia Informationen 39, 57-59.

Engl,W. 2012. Shells of Antarctica. ConchBooks, Hackenheim, Germany. Fedosov, A.E. \& Puillandre, N. (2012): Phylogeny and taxonomy of the KermiaPseudodaphnella (Mollusca: Gastropoda: Raphitomidae) genus complex: a remarkable radiation via diversification of larval development. Systematics and Biodiversity 10, 447477.

Figueira, R.M.A. \& Absalão, R.S. (2010) Deep-water Drilliinae, Cochlespirinae and Oenopotinae (Mollusca: Gastropoda: Turridae) from the Campos Basin, southeast Brazil. Scientia Marina 74, 471-481.

Gaillard, J. (1954) III. Mollusques. In Tcherna P., Missions du batiment polaire "Commandant Charcot". Récoltes faites en Terre Adélie (1950). Bulletin du Muséum National d'Histoire Naturelle, série $2^{\circ}$ 26, 678-685.

Gofas, S. (2015). Conoidea. In: MolluscaBase (2015). Accessed through: World Register of Marine Species at http://www.marinespecies.org/aphia.php?p=taxdetails\&id=15140 on 2015-07-26

Gofas S., Kantor, Yu. \& Luque, Á. A. (2014) A new Aforia (Gastropoda: Conoidea: Cochlespiridae) from Galicia Bank (NW Iberian Peninsula). Iberus 32, 45-51.

Hain, S.G. (1990) Beiträge zur Biologie der beschalten Mollusken (Kl. Gastropoda und Bivalvia) des Weddellmeeres, Antarktis. Berichte zur Polarforschung 70: 1-181.

Harasewych, M. G. \& Kantor, Yu. I. (2004) The deep-sea Buccinoidea (Gastropoda:

Neogastropoda) of the Scotia Sea and adjacent abyssal plains and trenches. The Nautilus $118,1-42$.

Harasewych, M. G., Sikaroodi, M. \& Gillevet, P.M. (2011) The Delray Beach, Florida colony of Cerion (Paracerion) tridentatum costellata Pilsbry, 1946 (Gastropoda: Pulmonata: Cerionidae): Evidence for indirect Cuban origins. The Nautilus 125, 173-181.

Hedley, C. (1916) Mollusca. Australasian Antarctic Expedition 1911-1914 Scientific Reports C Zoology and Botany 4 (1), 1-80.

Higo S., Callomon P., \& Gotô Y. (1999) Catalogue and bibliography of the marine shell-bearing Mollusca of Japan. Elle Scientific Publications, Osaka, Japan. 
Huelsenbeck, J.P., Ronquist, F. \& Hall, B. (2001) MrBayes: bayesian inference of phylogeny. Bioinformatics 17, 754-755.

Kantor, Y. I. \& Harasewych, M. G. (1999) Rediscovery of the Antarctic species Sipho gaini Lamy, 1910 (Gastropoda: Neogastropoda) with remarks on its taxonomic position. Antarctic Research 11, 431-436.

Kantor Yu.I., \& Harasewych M.G. (2013) Antarctica, where turrids and whelks converge: A revision of Falsimohnia Powell, 1951 (Neogastropoda: Buccinoidea) and a description of a new genus. The Nautilus 127, 43-56.

Kantor Yu. I. \& Puillandre N. (2012) Evolution of the radular apparatus in Conoidea (Gastropoda: Neogastropoda) as inferred from a molecular phylogeny. Malacologia 55, 55-90. DOI 10.4002/040.055.0105

Kantor Yu. I. \& Sysoev, A.V. (2006) Marine and brackish-water Gastropoda of Russia and adjacent countries: an illustrated catalogue. KMK Scientific Press Ltd., Russia (in Russian and English).

Lamy, E. (1910) Gastéropodes prosobranches et Scaphopode. Mission dans l'Antarctique dirigée par M. le Dr. Charcot (1908-1910). Bulletin du Musee d'Histoire Naturelle de Paris, 6: $318-324$.

Lamy, E. (1911) Gastropodes prosobranches, Scaphopode et Pélécypodes. Deuxième Expédition antarctique française (1908-1910) Sciences Naturelles: Document Scientifiques: 1-32.

Locard, A. (1897) Expéditions Scientifiques du Travailleur et du Talisman. Mollusques testacés. Vol. 1. Masson, Paris.

Lundberg, J., Schander, C. \& Stokland, Ø. (1996) A preliminary cladistic analysis of North Atlantic Oenopota Moerch, 1852 and Propebela Iredale, 1918 (Gastropoda: Conoidea). Journal of Molluscan Studies 62, 289-298. DOI 10.1093/mollus/62.3.289

Martens, E. von (1880-1881) Conchologische Mittheilungen als Fortsetzung der Novitates Conchologicae. Vol. 1. Theodor Fischer, Cassel. [Published in parts, Heft 1-4, 1-72 pp., pls. 1-12, in 1880, Heft 5/6, 73-101 pp., pls. 13-18, in 1881.]

Melvill, J. C. \& Standen, B. (1912) The marine Mollusca of the Scottish National Antarctic Expedition. Part II. Being a supplementary catalogue. Transactions of the Royal Society of Edinburgh 48: 333-366, 1 pl.

Moore, J. K., Abbott, M. R. \& Richman, J. G. (1999) Location and dynamics of the Antarctic Polar Front from satellite sea surface temperature data. Journal of Geophysical Research 104, no. C2, 3059-3073. 
Numanami, H. (1996) Taxonomic study on Antarctic gastropods collected by Japanese Antarctic research expeditions. Memoirs of the National Institute of Polar Research, series E 39, 1244.

Oliverio, M. \& Modica, M.V. (2010) Relationships of the haematophagous marine snail Colubraria (Rachiglossa: Colubrariidae), within the neogastropod phylogenetic framework. Zoological Journal of the Linnean Society 158, 779-800.

Orsi, A. H., Whitworth III, T. \& Nowlin Jr., W. D. (1995) On the meridional extent and fronts of the Antarctic Circumpolar Current. Deep Sea Research, Part I 42, 641-673.

Pacaud, J.-M. \& Le Renard, J. (1995) Révision des Mollusques Paléogénes du Bassin de Paris. IV - Liste systématique actualisée.Cossmanniana 3(4), 155-187.

Powell, A.W.B. (1942) The New Zealand Recent and fossil Mollusca of the family Turridae with general notes on turrid nomenclature and systematics. Bulletin of the Auckland Institute and Museum 2, 1-188, 14 pls.

Powell, A.W.B. (1951) Antarctic and subantarctic Mollusca: Pelecypoda and Gastropoda. Discovery Reports 26: 47-196.

Powell, A.W.B. (1958) Mollusca from the Victoria-Ross Quadrants of Antarctica. B.A.N.Z. Antarctic Research Expedition 1929-1931. Reports-Series B 6(9), 167-215.

Powell, A.W.B. (1960) Antarctic and subantarctic Mollusca. Records of the Auckland Institute and Museum 5, 117-193.

Powell, A.W.B. (1966) The molluscan families Speightiidae and Turridae: an evaluation of the valid taxa, both Recent and fossil, with lists of characteristic species. Bulletin of the Auckland Institute and Museum 5, 1-184.

Powell, A.W.B. (1969) The family Turridae in the Indo-Pacific. Part 2. The subfamily Turriculinae. Indo-Pacific Mollusca 2, 207-415 [23-191-23-639 - pagination of the series Indo-Pacific Mollusca].

Puillandre, N., Kantor, Yu.I., Sysoev, A., Couloux, A., Meyer, C., Rawlings, T., Todd, J.A. \& Bouchet, P. (2011) The dragon tamed? A molecular phylogeny of the Conoidea (Gastropoda). Journal of Molluscan Studies 77, 259-272. DOI 10.1093/mollus/eyr015

Rambaut, A. \& Drummond, A.J. (2007) Tracer v1.4. Available from http://beast.bio.ed.ac.uk/Tracer.

Schnetler, K. I. \& Palm, E. (2008) The molluscan fauna of the late Oligocene Branden Clay, Denmark. Palaeontos 15: 1-92.

Schwabe, E., Bohn, J.M., Engl, W., Linse, K. \& Schrödl, M. (2007) Rich and rare - first insights into species diversity and abundance of Antarctic abyssal Gastropoda (Mollusca). Deep Sea Research II 54, 1831-1847. 
Spencer, H.G., Marshall, B. A., Maxwell, P.A., Grant-Mackie, J.A., Stilwell, J.D., Willan, R.C., Campbell, H.J., Crampton, J.S., Henderson, R.A., Bradshaw, M.A., Waterhouse, J.B. \& Pojeta, J. Jr. (2009) Phylum Mollusca. Chitons, clams, tusk shells, squids and kin. In: Gordon, D.P. (Ed), New Zealand inventory of biodiversity. Volume one. Kingdom Animalia. Radiata, Lophotrochozoa, Deuterostomia. Canterbury University Press, Christchurch, pp. 161-254.

Spencer, H.G., Willan, R.C., Marshall, B. \& Murray, T.J. (2014) Checklist of the Recent Mollusca recorded from the New Zealand Exclusive Economic Zone.

http://www.molluscs.otago.ac.nz/index.html

Strebel, H. (1908) Die Gastropoden. Wissenschaftliche Ergebnisse der schwedischen Südpolar Expedition. 1901-1903 6, 1-112.

Sysoev, A.V. (1996a) Deep-sea conoidean gastropods collected by the John Murray Expedition, 1933-34. Bulletin of the Natural History Museum of London, Zoology 62, 1-30.

Sysoev, A.V. (1996b) Taxonomic notes on South African deep-sea conoidean gastropods (Gastropoda: Conoidea) described by K.H. Barnard, 1963. The Nautilus 110, 22-29.

Sysoev, A.V. \& Kantor, Yu.I. (1987) Deep-sea gastropods of the genus Aforia (Turridae) of the Pacific: species composition, systematics, and functional morphology of the digestive system. The Veliger 30, 105-126.

Taylor, J.D., Kantor, Yu.I. \& Sysoev, A.V. (1993) Foregut anatomy, feeding mechanisms, relationships and classification of Conoidea (=Toxoglossa) (Gastropoda). Bulletin of the natural History Museum, London (Zoology) 59: 125-169.

Thiele, J. 1912. Die antarktischen Schnecken und Muscheln. Deutsche Südpolar Expedition 1901-1903 13, 183-285.

Thiele, J. (1929) Handbuch der Systematischen Weichtierkunde. Vol. 1. Gustave Fischer, Jena. Troncoso, J.S. \& Aldea, C. (2008) Macrobenthic mollusc assemblages and diversity in the West Antarctica from the South Shetland islands to the Bellinghausen Sea. Polar Biology 31, 1253-1265.

Tucker, J.K. (2004) Catalog of Recent and fossil turrids (Mollusca: Gastropoda). Zootaxa 682, $1-1295$.

Verrill, A. H. (1872) Brief contributions to zoology, from the Museum of Yale College. No. XXIII. Results of recent dredging expeditions on the coast of New England. American Journal of Science and Arts (Series 3) 5, 1-16.

Watson, R.B. (1881) Mollusca of H.M.S. Challenger Expedition. Parts VIII-X. Journal of the Linnean Society (London) 15, 388-475. 
Watson, R. B. (1886) Report on the Scaphopoda and Gasteropoda collected by H.M.S. Challenger during the years 1873-1876. Report on the Scientific Results of the Voyage of H.M.S. Challenger. Zoology 15: 1-756.

Wiese, V. (2001) Comments on a "new” turrid species from Kerguelen. Scriften zur Malakozoologie 18, 33-34.

Zelaya D.G. (2005) Systematics and zoogeography of marine gastropod molluscs of South Georgia. Spixiana 28: 109-139. 
Table 1. Species included in the present work to compile the molecular dataset, with voucher registration and GENBANK accession numbers.

\begin{tabular}{|c|c|c|c|c|c|c|}
\hline Family & Species & Registration no. & Distribution & Coordinates & Depth, m & COI GB \\
\hline Mangeliidae & Eucithara coronata (Hinds, 1843) & MNHN IM-2007-17900 & Philippines & 9³7'5.988"N; 12346'5.9988"E & intertidal & EU015674 \\
\hline Mangeliidae & Benthomangelia sp. & MNHN IM-2007-17930 & Solomon Islands & 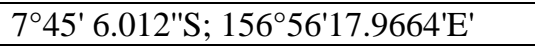 & $768-890$ & EU015743 \\
\hline Mangeliidae & $\begin{array}{l}\text { Benthomangelia cf._trophonoidea } \\
\text { (Schepman, 1913) }\end{array}$ & MNHN IM-2007-17835 & Vanuatu & 16³7'30.5976"S; 16757'22.7844"E & $618-641$ & EU015644 \\
\hline Mangeliidae & $\begin{array}{l}\text { Toxicochlespira pagoda Sysoev\& Kantor, } \\
1990\end{array}$ & MNHN IM-2007-17915 & Philippines & $8^{\circ} 43^{\prime} 18.012 " \mathrm{~N} ; 123^{\circ} 19^{\prime} 0.0228^{\prime \prime E}$ & $259-280$ & EU015730 \\
\hline Mangeliidae & Propebela cf. scalaris (Møller, 1842) & MNHN IM-2007-42325 & $\begin{array}{l}\text { Norway, } \\
\text { Spitzbergen, } \\
\text { Hornsund, Svalbard }\end{array}$ & & & HQ401582 \\
\hline Mangeliidae & Propebela cf. scalaris (Møller, 1842) & MNHN IM-2007-42326 & $\begin{array}{l}\text { Norway, } \\
\text { Spitzbergen, } \\
\text { Hornsund, Svalbard }\end{array}$ & & & KT448823 \\
\hline Mangeliidae & Lorabela pelseneri (Strebel, 1908) & USNM 1121974 & Antarctic Peninsula & $63^{\circ} 40^{\prime} 4.7994^{\prime \prime S}, 57^{\circ} 18^{\prime} 56.4114^{\prime \prime W}$ & 260 & KT448824 \\
\hline Mangeliidae & Lorabela plicatula (Thiele, 1912) & USNM 1121967 & Antarctic Peninsula & $63^{\circ} 40^{\prime} 4.7994^{\prime \prime S}, 57^{\circ} 18^{\prime} 56.4114 " \mathrm{~W}$ & 260 & KT448825 \\
\hline Mangeliidae & Lorabela plicatula (Thiele, 1912) & USNM 1121969 & Antarctic Peninsula & $63^{\circ} 40^{\prime} 4.7994^{\prime \prime S}, 57^{\circ} 18^{\prime} 56.4114^{\prime \prime W}$ & 260 & KT448826 \\
\hline Borsoniidae & Borsonia sp. & MNHN IM-2007-17839 & Coral Sea & $21^{\circ} 7^{\prime} 0.0156^{\prime \prime S} ; 158^{\circ} 30^{\prime} 0.0^{\prime \prime E}$ & $800-923$ & EU015665 \\
\hline Borsoniidae & Bathytoma visagei Kilburn, 1973 & MNHN IM-2009-6252 & $\begin{array}{l}\text { Mozambique } \\
\text { Channel }\end{array}$ & $23^{\circ} 31^{\prime} 40.188^{\prime \prime}$ S; 35²4'45.612"E & $264-277$ & KT448827 \\
\hline Borsoniidae & $\begin{array}{l}\text { Bathytoma episoma Puillandre, Sysoev, } \\
\text { Olivera, Couloux \& Bouchet, } 2010\end{array}$ & MNHN IM-2007-18061 & Philippines & $15^{\circ} 58^{\prime} 8.4^{\prime \prime N} ; 121^{\circ} 49^{\prime} 13.206^{\prime \prime E}$ & $418-456$ & EU592111.1 \\
\hline Borsoniidae & Bellaturricula gaini (Lamy, 1910) & USNM 1121911 & Antarctic Peninsula & 648'19.32"S; 6245'35.9994"W & 156 & KT448828 \\
\hline Borsoniidae & Bellaturricula gaini (Lamy, 1910) & USNM 1121929 & Antarctic Peninsula & $63^{\circ} 40^{\prime} 12^{\prime \prime}$; $61^{\circ} 10^{\prime} 12^{\prime \prime W}$ & 126 & KT448829 \\
\hline Borsoniidae & $\begin{array}{l}\text { Bellaturricula turrita multispiralis Dell, } \\
1990\end{array}$ & USNM 1122047 & Antarctic Peninsula & $63^{\circ} 8^{\prime} 50.28 " \mathrm{~S} ; 57^{\circ} 7 ' 26.4^{\prime \prime W}$ & $146-192$ & KT448830 \\
\hline Borsoniidae & $\begin{array}{l}\text { Bellaturricula turrita multispiralis Dell, } \\
1990\end{array}$ & USNM 1121893 & Antarctic Peninsula & $63^{\circ} 8^{\prime} 50.28 " \mathrm{~S} ; 57^{\circ} 7^{\prime} 26.4^{\prime \prime} \mathrm{W}$ & $146-192$ & KT448831 \\
\hline Borsoniidae & Bellaturricula ergata (Hedley, 1916) & MNHN IM-2009-8165 & Adélie Land & $66^{\circ} 01^{\prime} \mathrm{S}, 142^{\circ} 43^{\prime} \mathrm{E}$ & $421-463$ & KT448832 \\
\hline Borsoniidae & Bellaturricula ergata (Hedley, 1916) & MNHN IM-2009-8177 & Adélie Land & $66^{\circ} 34^{\prime} \mathrm{S}, 141^{\circ} 20^{\prime} \mathrm{E}$ & $170-210$ & KT448833 \\
\hline Borsoniidae & Bellaturricula ergata (Hedley, 1916) & MNHN IM-2009-8189 & Adélie Land & $65^{\circ} 29^{\prime} \mathrm{S}, 139^{\circ} 19^{\prime} \mathrm{E}$ & $397-411$ & KT448834 \\
\hline Borsoniidae & Genota mitriformis (Wood, 1828) & MNHN IM-2007-42293 & Angola, Pta. Das & & $30-50$ & HQ401576 \\
\hline
\end{tabular}




\begin{tabular}{|c|c|c|c|c|c|c|}
\hline & & & Lagostas & & & \\
\hline Cochlespiridae & Comitas bolognai Bozzetti, 2001 & MNHN IM-2007-17916 & Philippines & $8^{\circ} 51^{\prime} 0.00 " \mathrm{~N} ; 123^{\circ} 10^{\prime} 0.0192 " \mathrm{E}$ & $982-989$ & EU015731 \\
\hline Cochlespiridae & Cochlespira pulchella (Schepman, 1913) & MNHN IM-2007-17842 & Coral Sea & $21^{\circ} 2^{\prime} 59.9964 " \mathrm{~S} ; 158^{\circ} 36^{\prime} 0.0216^{\prime \prime E}$ & $352-370$ & EU015651 \\
\hline Cochlespiridae & Cochlespira sp & MNHN IM-2007-40568 & Coral Sea & $21^{\circ} 10^{\prime} 0.012^{\prime \prime S} ; 158^{\circ} 38^{\prime} 59.9784^{\prime \prime E}$ & $650-723$ & EU685627 \\
\hline Cochlespiridae & Aforia hedleyi (Dell, 1990) & MNHN IM-2009-8188 & Adélie Land & $65^{\circ} 29^{\prime} \mathrm{S}, 139^{\circ} 19^{\prime} \mathrm{E}$ & $414 \mathrm{~m}$ & KT448835 \\
\hline Cochlespiridae & $\begin{array}{l}\text { Aforia serranoi Gofas, Kantor \& Luque, } \\
2014\end{array}$ & MNCN15.05/60099 & East of Galicia Bank & $42^{\circ} 41.875^{\prime} \mathrm{N} ; 11^{\circ} 26.708^{\prime} \mathrm{W}$ & 1720 & KT448836 \\
\hline Cochlespiridae & Aforia magnifica (Strebel, 1908) & USNM 1121900 & Bellinsgausen Sea & $65^{\circ} 39^{\prime} 50.58^{\prime \prime S}, 68^{\circ} 2^{\prime} 13.4406^{\prime \prime} \mathrm{W}$ & 282 & KT448837 \\
\hline Cochlespiridae & Aforia magnifica (Strebel, 1908) & ZSM 20021143 & Weddell Sea & 62³4'47.9994"S; 5540'12"W & & FM999160.1 \\
\hline Cochlespiridae & Aforia magnifica (Strebel, 1908) & USNM 1121894 & Antarctic Peninsula & $63^{\circ} 8^{\prime} 50.28^{\prime \prime S}, 57^{\circ} 7^{\prime} 26.4^{\prime \prime} \mathrm{W}$ & $146-192$ & KT448838 \\
\hline Pseudomelatomidae & Conorbela antarctica (Strebel, 1908) & USNM 1121892 & $\begin{array}{l}\text { South Shetland } \\
\text { Islands, Elephant } \\
\text { Island }\end{array}$ & $62^{\circ} 45^{\prime} \mathrm{S}, 56^{\circ} 45^{\prime} \mathrm{W}$ & 207 & KT448839 \\
\hline
\end{tabular}


Table 2. Pleurotomella (Pleurotomella) tippetti, shell measurements (mm)

\begin{tabular}{|l|c|c|c|c|}
\hline Specimen & Shell length & $\begin{array}{c}\text { Last whorl } \\
\text { length }\end{array}$ & Aperture length & Shell width \\
\hline Holotype & 12.5 & 9.8 & 7.9 & 7.0 \\
\hline Paratype & 13.0 & 10.2 & 8.3 & 6.7 \\
\hline
\end{tabular}

Table 3. Pleurotomella (Anomalotomella) petiti, shell measurements (mm).

\begin{tabular}{|l|c|c|c|c|}
\hline Specimen & Shell length & $\begin{array}{c}\text { Last whorl } \\
\text { length }\end{array}$ & Aperture length & Shell width \\
\hline Holotype & 4.3 & 3.3 & 2.9 & 2.7 \\
\hline Paratype & 5.7 & 4.2 & 3.7 & 3.5 \\
\hline
\end{tabular}

Table 4. Species richness, geographical and bathymetric distribution of genera of Conoidea, recorded in Antarctic waters.

\begin{tabular}{|c|c|c|c|c|c|}
\hline Family & Genus (subgenus) & $\begin{array}{l}\text { Total No } \\
\text { of species } \\
\text { and } \\
\text { subspecies }\end{array}$ & $\begin{array}{c}\text { No. of } \\
\text { species } \\
\text { and } \\
\text { subspecies } \\
\text { in } \\
\text { Antarctica }\end{array}$ & $\begin{array}{l}\text { Distribution: } \\
\text { A - Antarctic, SA - } \\
\text { subantarctic, BR - } \\
\text { broad distribution }\end{array}$ & $\begin{array}{c}\text { Depth range in } \\
\text { Antarctica (our } \\
\text { data and published } \\
\text { records) }\end{array}$ \\
\hline \multirow[t]{4}{*}{ Borsoniidae } & $\begin{array}{c}\text { Antarctospira } \\
\text { new genus }\end{array}$ & 5 & 3 & A, SA & $193-1400$ \\
\hline & $\begin{array}{l}\text { Belaturricula } \\
\text { Powell, } 1951\end{array}$ & 5 & 4 & $\overline{B R}$ & $70-695$ \\
\hline & $\begin{array}{c}\text { Drilliola Locard, } \\
1897\end{array}$ & 3 & 1 & BR & $662-1120$ \\
\hline & $\begin{array}{l}\text { Typhlodaphne } \\
\text { Powell, } 1951\end{array}$ & 4 & 2 & A, SA & $90-3510$ \\
\hline \multirow[t]{2}{*}{ Mangeliidae } & $\begin{array}{c}\text { Lorabela Powell, } \\
1951\end{array}$ & 4 & 4 & A & $98-640$ \\
\hline & $\begin{array}{c}\text { Belalora Powell, } \\
1951\end{array}$ & 3 & 2 & A, SA & $193-4805$ \\
\hline \multirow[t]{2}{*}{ Raphitomidae } & $\begin{array}{c}\text { Pleurotomella } \\
\text { (Pleurotomella) } \\
\text { Verrill } 1873\end{array}$ & 74 & 2 & BR & $2359-5700$ \\
\hline & $\begin{array}{c}\text { Pleurotomella } \\
\text { (Anomalotomella) }\end{array}$ & 12 & 12 & A, Sa & $30-600$ \\
\hline
\end{tabular}




\begin{tabular}{|l|c|c|c|c|c|}
\hline & $\begin{array}{c}\text { Xanthodaphne } \\
\text { Powell, 1942 }\end{array}$ & 31 & 3 & BR & $99-4,540$ \\
\hline Cochlespiridae & Aforia Dall, 1889 & 20 & 5 & BR & $92-4963$ \\
\hline Pseudomelatomidae & $\begin{array}{c}\text { Conorbela } \\
\text { Powell, 1951 }\end{array}$ & 1 & 1 & A & BR \\
\hline Horaiclavidae & $\begin{array}{c}\text { Micropleurotoma } \\
\text { Thiele, 1925 }\end{array}$ & 4 & 1 & & $193-3816$ \\
\hline Turridae & ? & 1 & 1 & & $205-1890$ \\
\hline Insertae sedis & "Leucosyrinx" & & 42 & & 177 \\
\hline Total & & & & & \\
\hline
\end{tabular}


Table 5. Relative abundance of Conoidea in Antarctic waters and other faunas.

\begin{tabular}{|c|c|c|c|c|c|c|}
\hline Region & $\begin{array}{l}\text { Total number } \\
\text { of } \\
\text { Neogastropoda } \\
\text { species }\end{array}$ & $\begin{array}{c}\text { Total } \\
\text { number } \\
\text { of } \\
\text { Conoidea } \\
\text { species }\end{array}$ & $\begin{array}{c}\text { Total } \\
\text { number of } \\
\text { "turrid" } \\
\text { species }\end{array}$ & $\begin{array}{c}\text { Conoidea as } \\
\text { \% of total } \\
\text { Neogastropod } \\
\text { species }\end{array}$ & $\begin{array}{l}\text { "Turrids" as } \\
\text { \% of total } \\
\text { Neogastropod } \\
\text { species }\end{array}$ & Source \\
\hline Antarctica & 160 & 42 & 42 & $26.2 \%$ & $26.2 \%$ & $\begin{array}{l}\text { Harasewych and Kantor } \\
\text { 2004; Engl 2012; Kantor } \\
\text { and Harasewych 2013; } \\
\text { herein }\end{array}$ \\
\hline $\begin{array}{l}\text { New } \\
\text { Zealand }\end{array}$ & 489 & 143 & 117 & $29.2 \%$ & $23.9 \%$ & Spencer et al. 2014 \\
\hline Russia & 488 & 130 & 129 & $26.6 \%$ & $26.6 \%$ & Kantor and Sysoev 2006 \\
\hline Japan & 2011 & 693 & 429 & $34.5 \%$ & $21.3 \%$ & Higo et al. 1999 \\
\hline $\begin{array}{l}\text { New } \\
\text { Caledonia }\end{array}$ & 723 & 352 & 263 & $48.7 \%$ & $36.4 \%$ & Bouchet et al. 2002 \\
\hline
\end{tabular}


Captions

Figure 1. Shells and radula of species of Antarctospira n. gen. A - F, Antarctospira badenpowelli (Dell, 1990); A, B, holotype, USNM 613118, Victoria Land, McMurdo Sound, east of Cape Hallett, $72^{\circ} 08$ 'S,172 $12^{\circ}$ 'E, 433 m, SL 19.9 mm; C, paratype, USNM 860180, South Shetland Islands, $72^{\circ} 06^{\prime} \mathrm{S}, 172^{\circ} 12^{\prime} \mathrm{E}, 433 \mathrm{~m}$, SL $21.5 \mathrm{~mm}$; D - F, radula of paratype; $\mathbf{D}$, teeth and radular membrane; E, single marginal tooth; F, tooth tip; G - J, Antarctospira principalis (Thiele, 1912); G, H, lectotype, ZMB 62984a, SL 13.7 mm; I, juvenile paralectotype, SL 5.0 mm; J, radula of paralectotype (after Thiele, 1912); K, Antarctospira mawsoni (Powell, 1958), holotype, SAM (D 15509), off Mackenzie Sea, 66º48'S, 71²24'E, 456 m, SL 37.75 mm; L, M, Antarctospira paragenota (Powell, 1951), holotype, BMNH 1961609, Burdwood Bank, south of

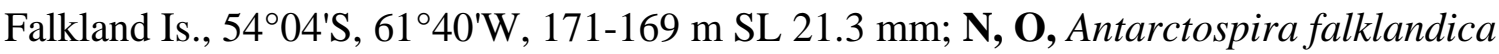
(Powell, 1951), holotype, BMNH 1961610, north of Falkland Is., 53¹6'S, 64²12'W, 336-342 m. SL $15.8 \mathrm{~mm}$. A - C, $\mathbf{K}-\mathbf{O}$, shells at the same scale.

Figure 2. Bayesian tree based on partial COI sequences showing relationships of Antarctic species of Bellaturricula and selected outgroups. Posterior probabilities are shown for each node.

Figure 3. Shells and radula of species of Bellaturricula. A - C, Belaturricula turrita turrita (Strebel, 1908); holotype of Bela turrita Strebel, 1908, Shag Rock Bank, 53³4'S, 43²3'W, 160 m, SL 60.0 mm; D - E, Belaturricula turrita multispiralis Dell, 1990; D, holotype, USNM 860139, Bransfield Strait, Antarctic Peninsula, 63¹4'S, 58²45'W, 73 m, SL 75.6 mm; E, USNM 1121893 (sequenced specimen), Antarctic Peninsula, 6309'S, 5707'12"W, 146-192 m, SL 74.0 mm; F - G, Belaturricula gaini (Lamy, 1910); F, USNM 860141, off South Shetland Islands, 6256.9'S, 6050.1'W, 154 m (holotype of Belaturricula antarctica Dell, 1990); G, USNM 1121929 (sequenced specimen), Antarctic Peninsula, 6340'8.76"S, 61¹0'3"W, 126 m, SL 53 mm. H - L, Belaturricula ergata (Hedley, 1916), MNHN IM-2009-8189, Adélie Land, 65²9'S, 139²19'E, 397-411 m; SL 81.4 mm. H, I, shell; J - L, radula; J, marginal teeth in different positions; K, enlarged tips of marginal teeth; $\mathbf{L}$, enlarged shell base. Shells at the same scale.

Figure 4. Shells and radula of Drilliola antarctica sp. nov., holotype, USNM 898821, South Shetland islands, Penguin Island, 6240'1.2"S, 5748'28.7994"W, 662-1120 m, SL 11.6 mm. A - B, ventral and dorsal views of the shell; $\mathbf{C}$, operculum; $\mathbf{D}-\mathbf{F}$, radula (D, part of the radular membrane with single row of marginal teeth; $\mathbf{E}$, separate marginal tooth; $\mathbf{F}$, tip of the tooth). 
Figure 5. Shells of species of Typhlodaphne. Typhlodaphne purissima (Strebel, 1908). A - F, syntypes of Bela purissima Strebel, 1908, Shag Rock Bank, 5334'S, 43²3'W, 160 m, SMNH Type-1061; A - C, SL 22.3 mm, D, enlarged operculum; E, SL 20.5 mm; F, enlarged protoconch. G, USNM 897551, off South Georgia, 55.27 S, 35.72 W, 180-186 m, SL 21.5 mm (radula see Fig. 6 A-C); H - I, USNM 896362, off South Georgia, 5459'S, 38¹3'W, 2196-2379 m, SL 27.0 and 31.9 mm; J, USNM 896521, NE of South Georgia Island, 5253'S, 3352'W, 2818-2855 m, SL 27.1 mm (radula see Fig. 6 D-F). K - L, Typhlodaphne strebeli Powell, 1951, holotype, NHMUK 1961617, between Cape Horn and Staten Island, 56²19.5'S, 6709.75'W, 121 m, SL $20.0 \mathrm{~mm}$. Shells at the same scale.

Figure 6. Radula and operculae of species of Typhlodaphne. A-F, Typhlodaphne purissima (Strebel, 1908); A - C, USNM 897551 (shell see Fig. 5 G); A, single marginal tooth; B, enlarged tip of marginal tooth; C, part of radular membrane; D - F, USNM 896521 (shell see Fig. 5 J); D, single marginal tooth; $\mathbf{E}$, enlarged tip of marginal tooth; $\mathbf{F}$, enlarged bases of marginal teeth. $\mathbf{G}$ M, Typhlodaphne paratenoceras (Powell, 1951); G - J, USNM 870249 (shell see Fig. 7 J-K); G, single marginal tooth; H, enlarged tip of marginal tooth; I, enlarged base of marginal tooth; J, operculum; K - M, USNM 870629 (shell see Fig. 7 G-H); K, single marginal tooth; L, M, enlarged tip of marginal tooth in different orientations; $\mathbf{N}-\mathbf{R}$, Typhlodaphne cf. paratenoceras, USNM 1113020, 5501'S, 3955'W, 2886-3040 m, SL 45. mm (shell see Fig. 7 N-O); N, O, single marginal tooth in different positions; $\mathbf{P}, \mathbf{Q}$, enlarged tip of marginal tooth in different positions; $\mathbf{R}$, operculum.

Figure 7. Shells of species of Typhlodaphne. A - K, Typhlodaphne paratenoceras (Powell, 1951); A - C, holotype, BMNH 1961607, between Penguin Island and Lion's Rump, King George Island, South Shetland Islands, 367-382 m, SL 38.8 mm; D - F, USNM 678478, South Orkney Islands, of North Laurie Island, 60³1'12"S, 44 46' 48"W, 761 m, SL 47.8 mm; G - H,

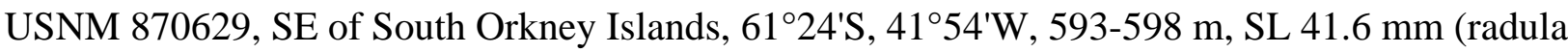
see Fig. 6 K-M); J - K, USNM 870249, South Shetland Islands, West of Elephant Island, 61ํ1'S, 5606'W, 220-240 m, SL 29.7 mm (radula see Fig. 11 G-J). L - M. Typhlodaphne cf. paratenoceras, USNM 1113020, South Georgia Island, off W tip of island, RV Eltanin, cruise 22, sta. 1537, 5501'S, 3955'W, 2886-3040 m, SL 39.9 mm, N - O, SL 45. mm (radula and operculum see Fig. $6 \mathrm{~N}-\mathrm{R}$ ). Shells at the same scale. 
Figure 8. Bayesian tree based on partial COI sequences showing relationships of Antarctic species of Lorabela and selected outgroups. Posterior probabilities are shown for each node.

Figure 9. Shells and radula of species of Lorabela. A - C, Lorabela pelseneri (Strebel, 1908); A, lectotype of Bela pelseneri, SMNH Type-1065, outer Cumberland Bay, South Georgia Island, 54 ${ }^{\circ} 11^{\prime} \mathrm{S}, 36^{\circ} 18^{\prime} \mathrm{W}, 252-310 \mathrm{~m}$, SL 7.6 mm; B, paralectotype, SMNH Type-5762, SL $7.9 \mathrm{~mm}$; C, USNM 1121974, Antarctic Peninsula, 6340'4.8"S, 57²18'56.4"W, 260 m, SL 7.5 mm, sequenced specimen; D - I, Lorabela glacialis (Thiele, 1912), syntypes of Bela glacialis Thiele, 1912, ZMB Mol 62985, Davis Sea, 6602'09"S, 89³8'E, 385 m; D - F, SL 5.4 mm (F enlarged protoconch); G, SL 5.2 mm; H, I, SL 9.0 mm; J - N, Lorabela plicatula (Thiele, 1912), syntypes of Bela plicatula Thiele, 1912, ZMB Mol 62986, Davis Sea, 6602'09"S, 89³8'E, 385 m; J - L, SL 6.2 mm (L - enlarged protoconch); M, SL 5.6 mm; N, SL 4.8 mm; O - R, USNM 1121967, Antarctic Peninsula, 6340'4.8"S, 57²18'56.52"W, 260 m, SL 11.1 mm; O, shell; P R, marginal radular teeth in different orientations. S, Lorabela davisi (Hedley, 1916), holotype of Oenopota davisi, AMS (C.46688), off Mertz Glacier tongue, Adelie Land, 66 52 'S, $145^{\circ} 30^{\prime} \mathrm{E}$, $527 \mathrm{~m}$, SL $7.0 \mathrm{~mm}$. Scale bars $-5 \mathrm{~mm}$ for shells, $1 \mathrm{~mm}$ for protoconchs. Shells at the same scale. (S, photo, courtesy of W. Engl and Conchbooks).

Figure 10. Shells of species of Belalora. A - F, Belalora striatula (Thiele, 1912); syntypes of Bela striatula Thiele, 1912, ZMB Mol 62987, Davis Sea, 6602'09"S, 89³8'E, 385 m; A - B, SL $4.3 \mathrm{~mm}$; C, protoconch of the same syntype, enlarged; D, SL $4.5 \mathrm{~mm}$; E - F, SL $3.8 \mathrm{~mm}$; G - I, Belalora weirichi (Engl, 2008); G, holotype of Oenopota weirichi, ZSM Mol 2005 1067, Weddell Abyssal Plain, 6534.34'S-36³1.18'W - 65ํ35.72'S-36²8.40'W, 4,794-4,805 m, SL 7

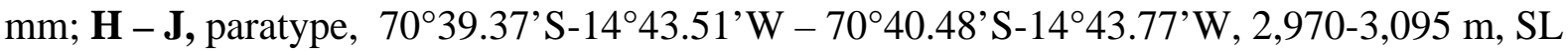
$4.72 \mathrm{~mm}$; H, SEM of he shell, $\mathbf{I}-\mathbf{J}$, protoconch. A - F at the same scale; $\mathbf{G}-\mathbf{H}$ at the same scale. (G - I, photos, courtesy of W. Engl and Conchbooks).

Figure 11. Shells of species of Pleurotomella (Pleurotomella). A - D, Pleurotomella maitasi Engl, 2008, Scotia Sea, 56 21'S, 5048'W, 5700-5650 m, SL 14.3 mm; A, B, ventral and dorsal views of the shell; $\mathbf{C}, \mathbf{D}$, lateral and apical views of the protoconch and upper teleoconch whorls; E - J, Pleurotomella tippetti new species, NW of Coronation Island, South Orkney Islands, 60²12.9'S, 435' W, 5450-5480 m; E - H, holotype, USNM SL 12.5 mm; E - F, ventral and dorsal views of the shell; $\mathbf{G}-\mathbf{H}$, lateral and apical views of the protoconch and upper teleoconch whorls; I - J, paratype, SL $13.0 \mathrm{~mm}$. Shells of Pleurotomella tippetti at the same scale. Arrows indicate protoconch/teleoconch border. 
Figure 12. Shells and radula of species of Pleurotomella (Anomalotomella). A - E, Pleurotomella (Anomalotomella) anomalapex Powell, 1951, UNSM 887840, NE of Zavodovski Island, South Sandwich Islands, 56²12'S, 27²3'53.9"W, 179-238 m, SL 6.3 mm; A, ventral; B, lateral; C, dorsal views of the shell; D, E, apical and lateral views of the protoconch; $\mathbf{F}$, Pleurotomella (Anomalotomella) bathybia Strebel, 1908, neotype, ZSM (Mol 2002 1313), South Georgia, 54²7.63'S, 3541.33'W, 256 m, SL 11 mm; G, Pleurotomella (Anomalotomella) frigida Thiele, 1912, lectotype, ZMB M.62982a, Davis Sea, 6602'09"S, 89³8'E, 385 m, SL 5.2 mm; H - K, Pleurotomella (Anomalotomella) annulata Thiele, 1912, USNM 1123584, South Shetland Islands, 6248'29.9"S, 6043'30"W, 203 m, SL 6.4 mm; H - I, ventral and dorsal views of the shell; $\mathbf{J}-\mathbf{K}$, marginal radular tooth (s - spur); $\mathbf{L}-\mathbf{M}$, Pleurotomella (Anomalotomella) deliciosa Thiele, 1912, holotype, ZMB (Moll 62980), Davis Sea, 6602'09"S, 89³8'E, 385 m, SL $4 \mathrm{~mm}$. Shells not to scale. (F, G, photos, courtesy of W. Engl and Conchbooks). Shells not to scale.

Figure 13. Shells of species of Pleurotomella (Anomalotomella). A - D, Pleurotomella (Anomalotomella) simillima Thiele, 1912; A - C, holotype, ZMB M.62983, Davis Sea, 6602'09"S, 89³8'E, 385 m SL 11 mm; A - B, shell; C, enlarged protoconch; D, USNM 898193, Ross Sea, Victoria Land, E of Moubray Pennell Bank, 730'S, 17806'W, 595-600 m, SL 5.7 mm; E, Pleurotomella (Anomalotomella) enderbyensis Powell, 1958, ZSM, Polarstern ANT 17/3 Ex p., Stn 159-1, Bransfield Strait, 6255,00' S, 57³9,50'W, 214-218 m, SL 5 mm; F, Pleurotomella (Anomalotomella) endeavourensis Dell, 1990, holotype, NMNZ (M.256622), off Enderby Land, 65²48'S, 5316'E, 193 m, SL 10.9 mm; G, Pleurotomella (Anomalotomella) rossi Dell 1990, holotype, NIWA (\# 276), Ross Sea, 7750'S, $166^{\circ} 30^{\prime} \mathrm{E}, 369$ m, SL 11.9 mm; H - L, Pleurotomella (Anomalotomella) innocentia (Dell, 1990), comb. nov., holotype, USNM 860147, Ross Sea, $72^{\circ} 00^{\prime} \mathrm{S}, 172^{\circ} 28^{\prime} \mathrm{E}, 530-549 \mathrm{~m}$, SL $4.2 \mathrm{~mm}$; H, ventral; I, lateral; J, dorsal views of the shell; K, L, lateral and apical views of protoconch. E, G, photos, courtesy of W. Engl and Conchbooks . (A-B, D, at the same scale; F, G, at the same scale).

Figure 14. Shells and radula of species of Pleurotomella (Anomalotomella). A - C, Pleurotomella (Anomalotomella) nipri (Numanami, 1996), comb. nov., holotype, NSMT-Mo 70633, Breid Bay, Queen Maud Land, Antarctica, 7009.0'S, 2346.3'E, 275-283 m, SL 3.1 mm; D - L, Pleurotomella (Anomalotomella) petiti n. sp. D - G, shell of holotype, USNM 1123582, between Deception and Livingston Islands, 6248'29.88"S, 6043'30"W, 203 m, SL 4.3 mm; D, ventral; E, dorsal; F, apical; G, apico-lateral views; H, I, SEM of shell of paratype, USNM 
1123581, same locality as the holotype, SL $5.7 \mathrm{~mm}$ (I, enlarged protoconch); J - L, marginal radular teeth of holotype, (s - spur); $\mathbf{L}$, enlarged tooth tip. A - C - photos courtesy of $\mathrm{K}$. Hasegawa.

Figure 15. Shells and radula of species of Xantodaphne. A - E, Xantodaphne translucida (Watson, 1881), syntypes of Pleurotoma (Thesbia) translucida, BMNH 1187.2.9.1041-3, st. 145, between Marion Island and Prince Edward Island, 4643'S, $38^{\circ} 04^{\prime} 30^{\prime \prime} E, 256$ m; A - D, SL 13.5 mm (D, enlarged protoconch); E, SL 14.1 mm. F - J, Xantodaphne raineri (Engl, 2008), comb. nov., IORAS, Davis Sea, 59²9'S, 9706.7' E, 4540 m; F - G, ventral and dorsal views of the shell, SL 32.5 mm; H, lateral view of the protoconch; I, radula; J, dissected anterior part of the cephalopodium. ct - cephalic tentacle; pr - proboscis; mb - muscular bulb of the venom gland; rhsp - rhynchostomal sphincter; s - spur.

Figure 16. Xanthodaphne pastorinoi n. sp., holotype, USNM 881354, Candlemas Island, South Sandwich islands, Scotia Sea; 5658'42”S, 26³0'36”W, 1,651-1,684 m, SL 23.0 mm. A, B ventral and dorsal views of the shell, $\mathbf{C}$ - enlarged shell apex; D - E - marginal radular teeth. All shells at the same scale. $\mathrm{s}$ - spur.

Figure 17. Bayesian tree based on partial COI sequences showing relationships of Antarctic and North Atlantic species of Aforia and selected outgroups. Posterior probabilities are shown for each node.

Figure 18. Shells and radula of species of Aforia. A - E, Aforia goniodes (Watson, 1881). A, B, lectotype, NHMUK 1887.2.9.970, south-east of Rio de la Plata, Argentina, 37²17'S, 52 ${ }^{\circ} 52^{\prime} \mathrm{W}$, 1,097 m, SL 22.9 mm; C, USNM 870341, NE of Falkland Island, 5153'59"S, 56³6'0"W, 855866 m, SL 27.9 mm; D, E, USNM 1123638, Argentina, 54²8'47.99"S, 62²12'36"W, 318 m; SL 18.2 mm (E, radula). F - I, Aforia watsoni nom. nov.; F - G - holotype of Pleurotoma (Surcula) lepta Watson, 1881, NHMUK 1889.11.11.7, southwest of Australia, 5355'S, 108³5'E, 3,566 m, SL 40.6 mm. H, USNM 896401, Southwest Pacific Basin, NE of Ross Sea, 5947'59"S, 144ํํ' 'W, 3,200-3,259 m, SL 40.2 mm. I, USNM 896402, Antarctic Peninsula, Graham Land, NE of Joinville Island, 6240'47.99"S, 5443'1.19"W, 210-220 m, SL 42.5 mm. A - D, at the same scale; $\mathbf{F}$ - I, at the same scale.

Figure 19. Shells and radula of species of Aforia. A - I, Aforia magnifica (Strebel, 1908); A - C, lectotype of Surcula magnifica, SMNH Type-1328, off Graham Land, Antarctica, 64은 
56 $6^{\circ} 7^{\prime} \mathrm{W}, 360$ m, SL 63.0 mm; C, enlarged protoconch; D, paralectotype, SL 54.9 mm; E, USNM 894456, South Sandwich Islands, Zavodovski Island, 56¹6'12"S, 27³0'W, 208-375 m, SL 89 mm; F, USNM 1121894, Antarctica, 6309'S, 57²7'12"W, 146-192 m, SL 66.5 mm (sequenced specimen); G - I, USNM 1121900, Bellinsgausen Sea, 65³9' 36"S, 68²'24"W, 282 m (G - shell, H - I - radula) (sequenced specimen). J - L, Aforia multispiralis Dell,1990; J - K, holotype, USNM 860145, off South Shetland Islands, 62²7'S, 5758' W, 1116-809 m, SL 57.0 mm; L, USNM 870023, South Shetland Islands, 62²'31.2"S, 61'31.2"W, 1437 m, SL 48.0 mm. al - accessory limb of the marginal tooth, ml - major limb of the marginal tooth. Shells at the same scale.

Figure 20. Shells and radula of Aforia hedleyi (Dell, 1990). A, holotype of Pontiothauma? hedleyi, USNM 860148, Ross Sea, $76^{\circ} \mathrm{S}, 165^{\circ} 6^{\prime} \mathrm{W}, 494-498$ m, SL 58.0; B, C, paratype, USNM 860149, SL 97.1 mm. D - F - Adelie Coast, 65²9'S, 139²19'E, 414 m, MNHN IM-2009-8188, SL (remaining part) $89.7 \mathrm{~mm}, \mathbf{D}$ - shell, $\mathbf{E}-\mathbf{F}$ - radula. Shells at the same scale.

Figure 21. Shells and radula of Conorbela antarctica (Strebel, 1908), A - B, syntype of Bela

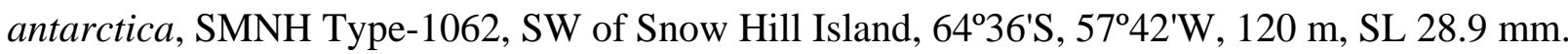
C - D. USNM 894465, Scotia Sea, South Sandwich Islands, Zavodovski Island, east of island,

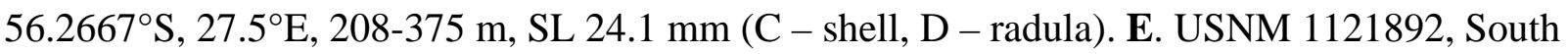
Shetland Islands, Elephant Island, Bransfield Strait, 6245'S, 56² 45'W, 207 m, SL 29 mm (sequenced specimen). Shells at the same scale.

Figure 22. A - D, Micropleurotoma remota (Powell, 1958), USNM 1187809, between Falkland Islands and South Georgia, 5259'31.20"S, 4853'31.2"W, 2928-3084 m, SL 8.5 mm; A, B, shell; C, D, radula. E - G, Micropleurotoma spirotropoides (Thiele, 1925), possible syntype, ZMB, SL 4.4 mm. H - L, "Lophiotoma" pseudoannulata Dell, 1990; H, I, holotype, USNM 860146, Ross Sea, 72.5 $\mathrm{S}, 177.1^{\circ} \mathrm{E}, 1883$ m, SL $19.0 \mathrm{~mm}$; J - L, USNM 898177, Ross Sea, 7555'12"S, 173¹6'48"W, 476 m, SL 7.5 mm; M, Leucosyrinx macrobertsoni Powell, 1958, holotype, SAM (D 15510), off MacRobertson Land, 66 $45^{\prime}$ S, 62 $03^{\circ} \mathrm{E}, 177 \mathrm{~m}$, SL $42.6 \mathrm{~mm}$. A, B, E, shells at the same scale, $\mathbf{F}$ - G, enlarged. $\mathbf{H}, \mathbf{I}, \mathbf{J}$, shells at the same scale, $\mathbf{K}-\mathbf{L}$, enlarged.

Figure 23. Bathymetric ranges of genera of Conoidea in Antarctic waters. A continental shelf; B, upper continental slope; C, lower continental slope; D, continental rise; E, abyssal plain; F, hadal depths. 
Figure 24. Species richness of Conoidea at different depths in Antarctic waters . A continental shelf; B, upper continental slope; C, lower continental slope; D, continental rise; E, abyssal plain; F, hadal depths. 


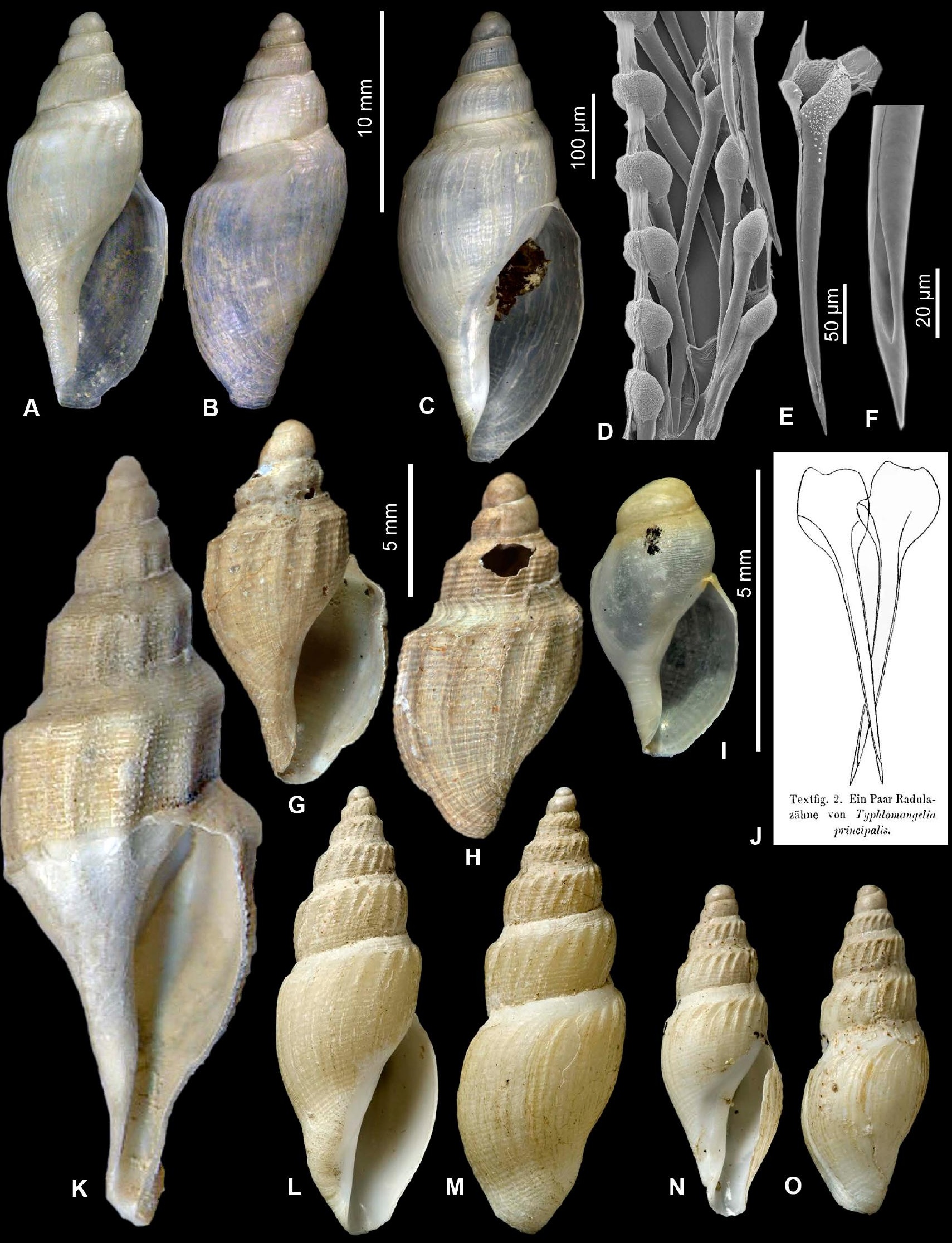




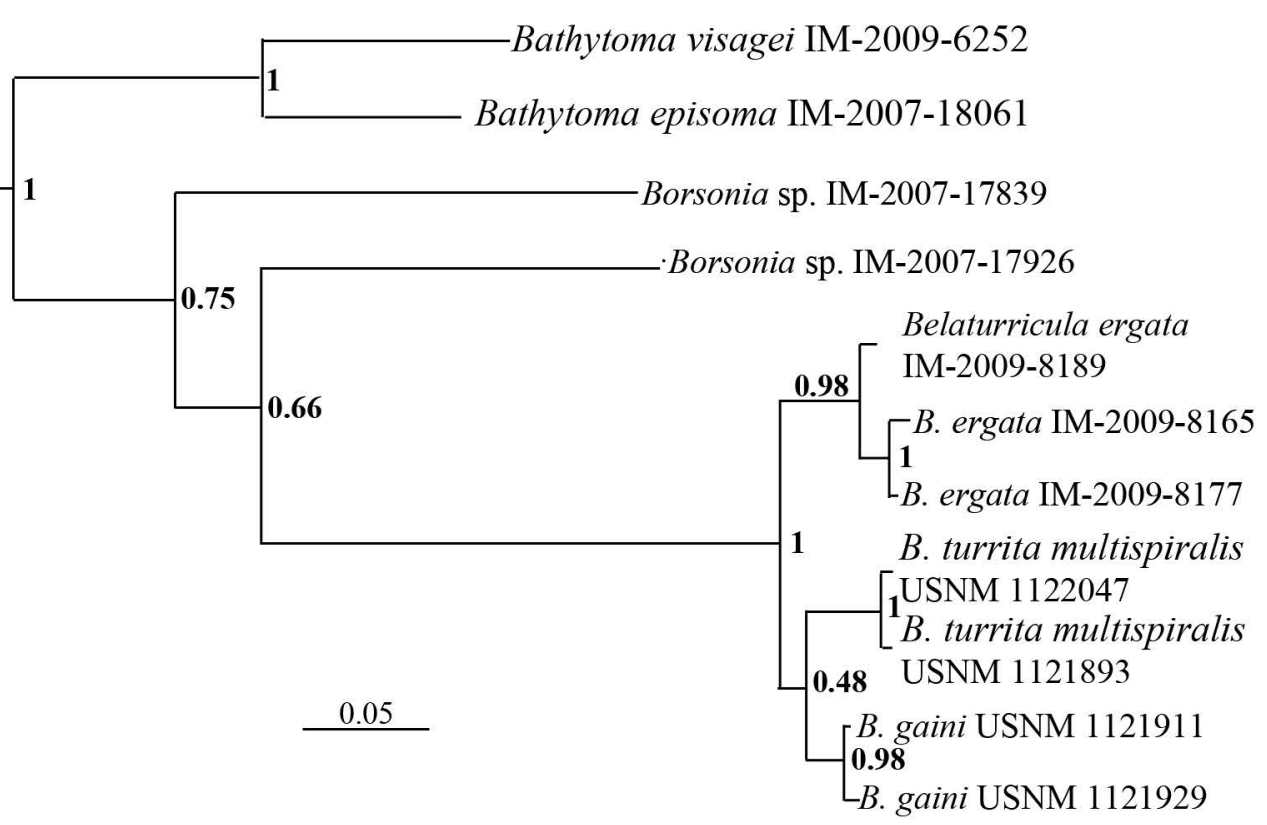





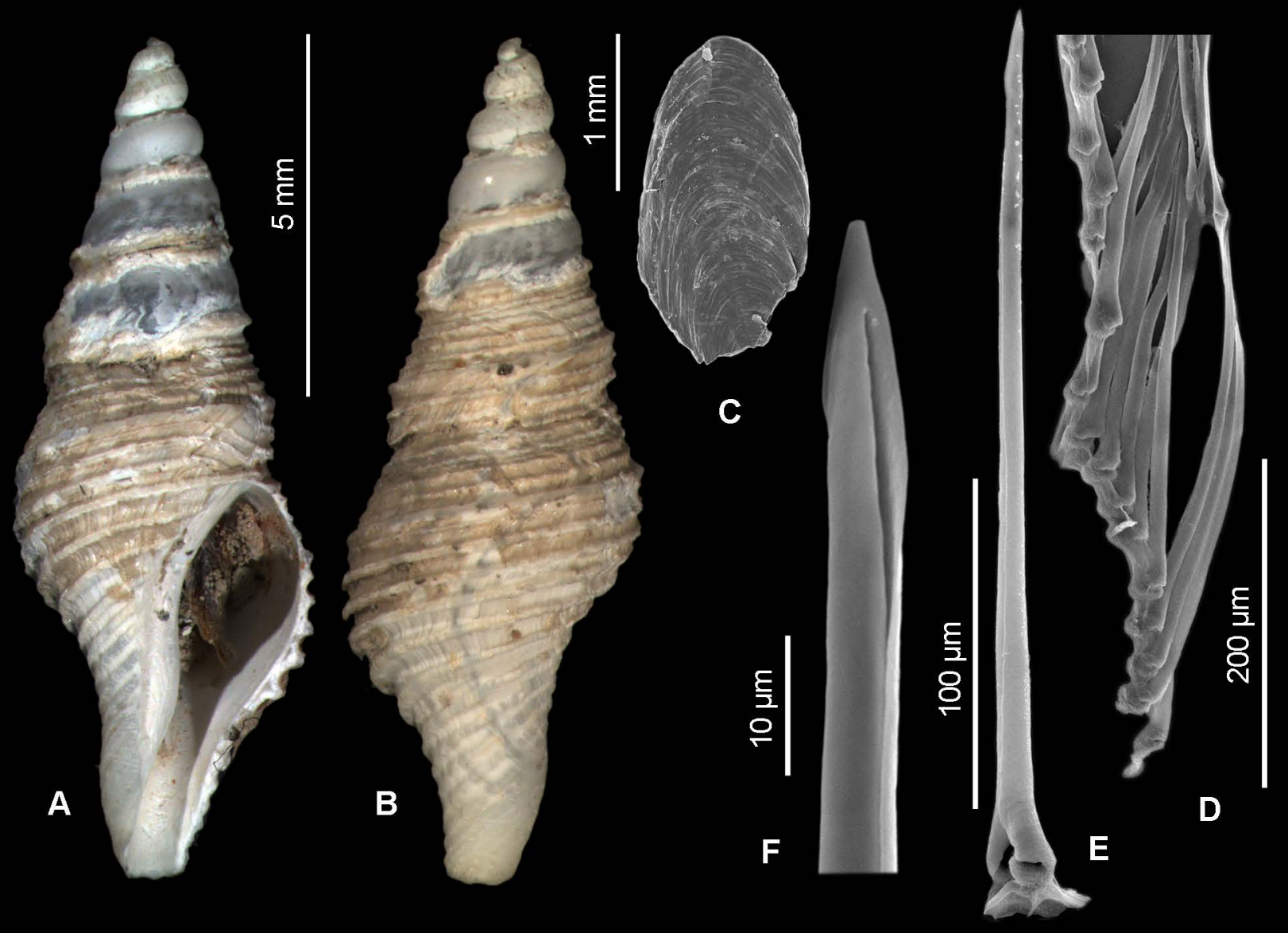




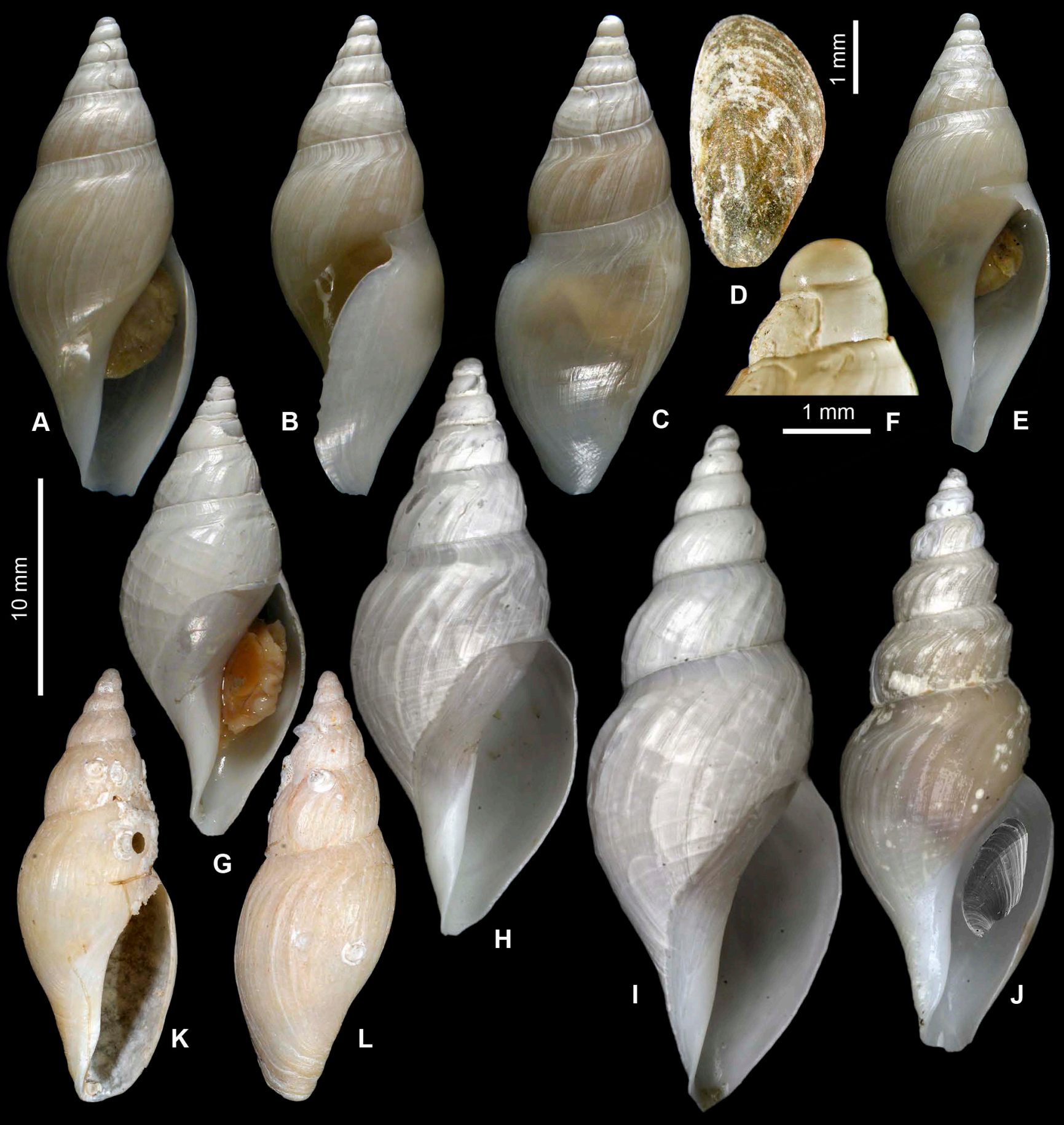





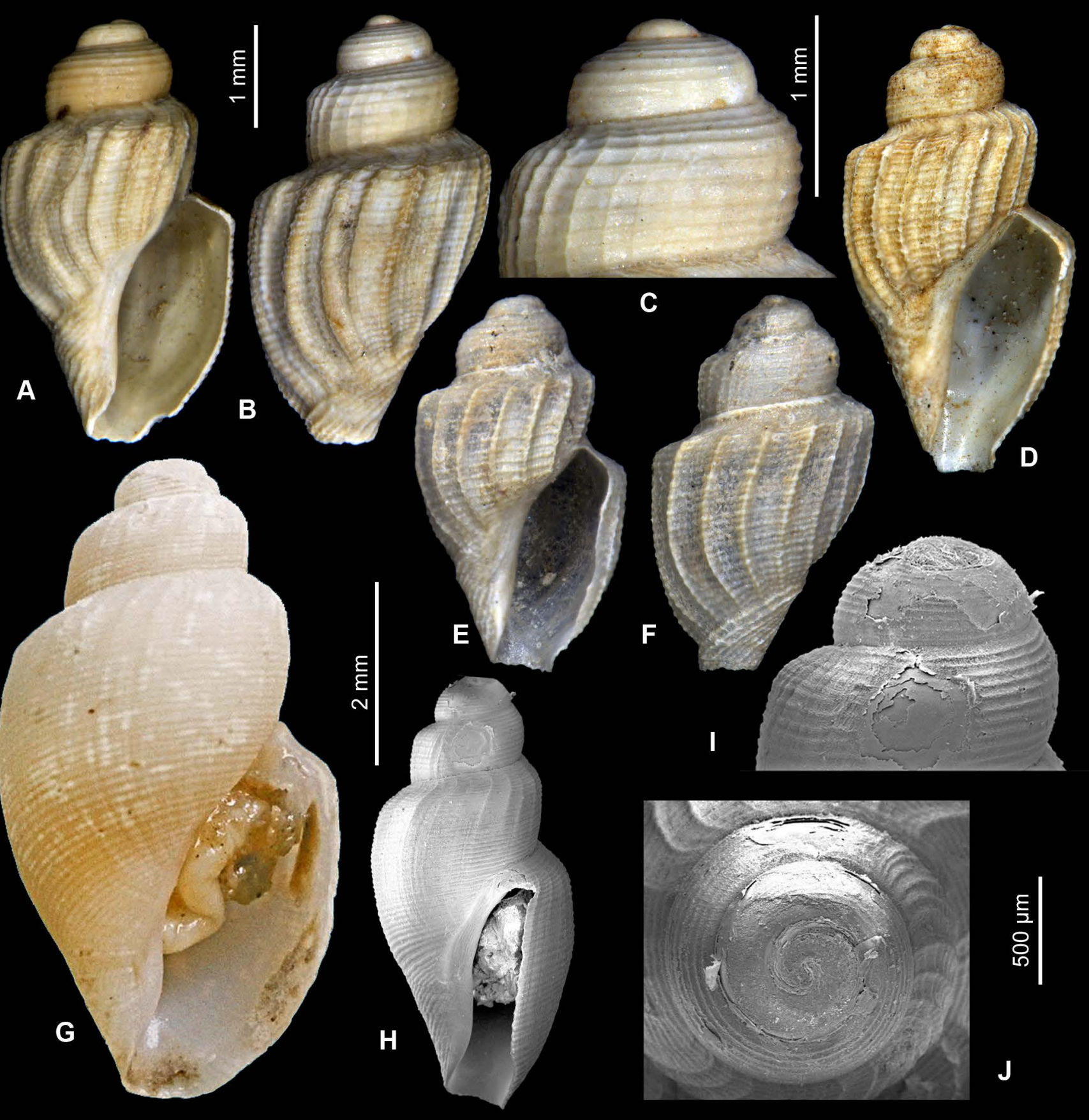




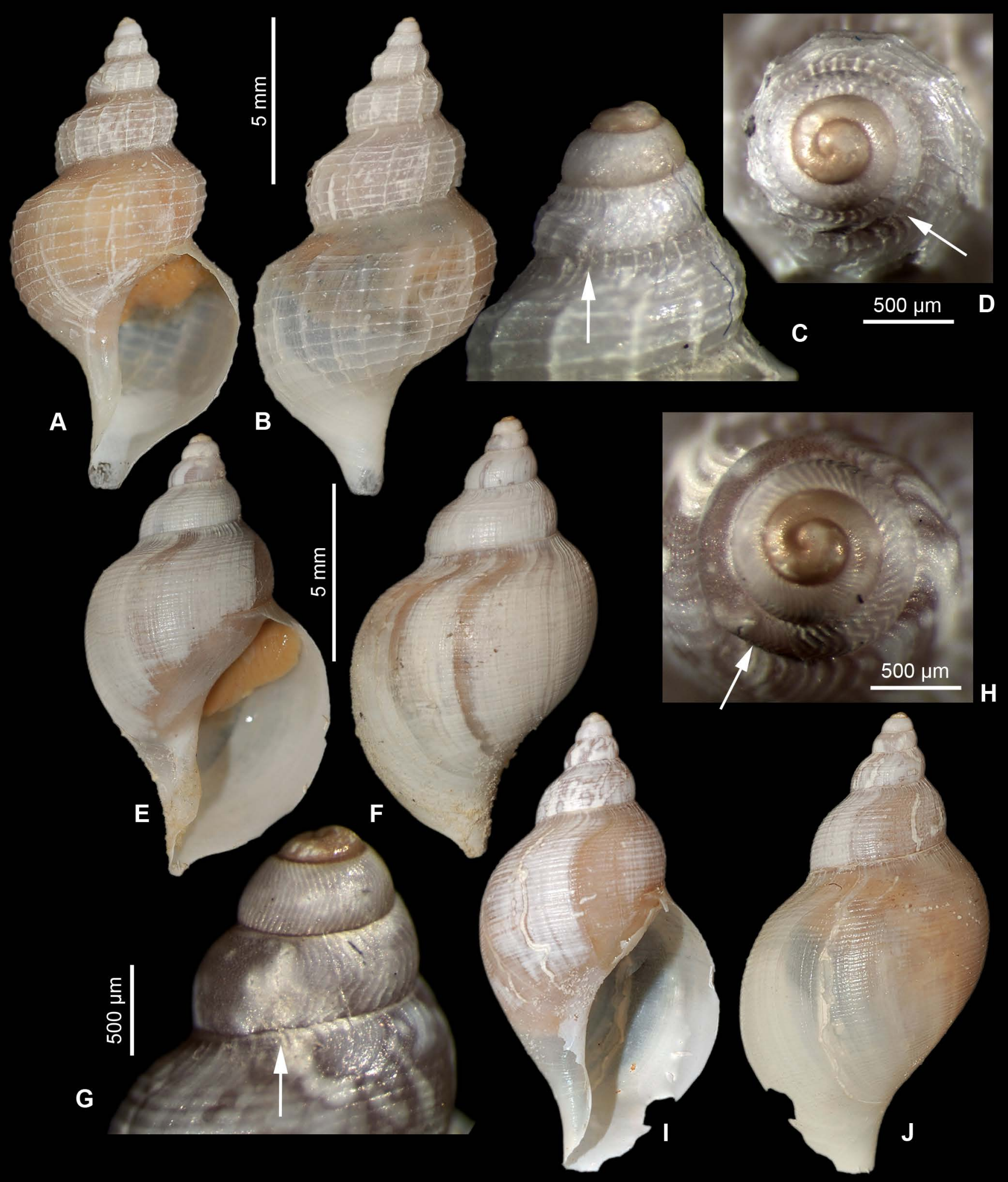




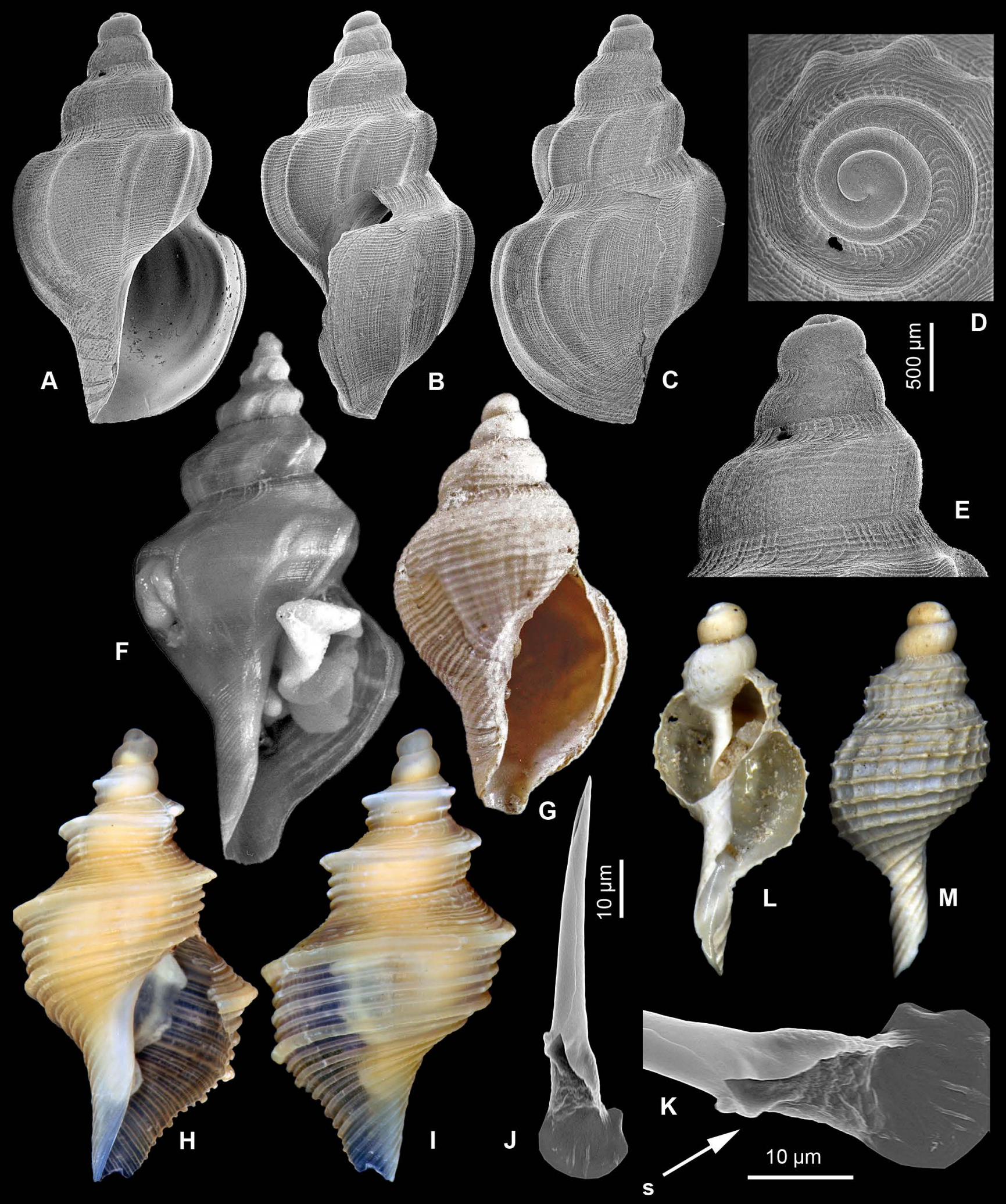




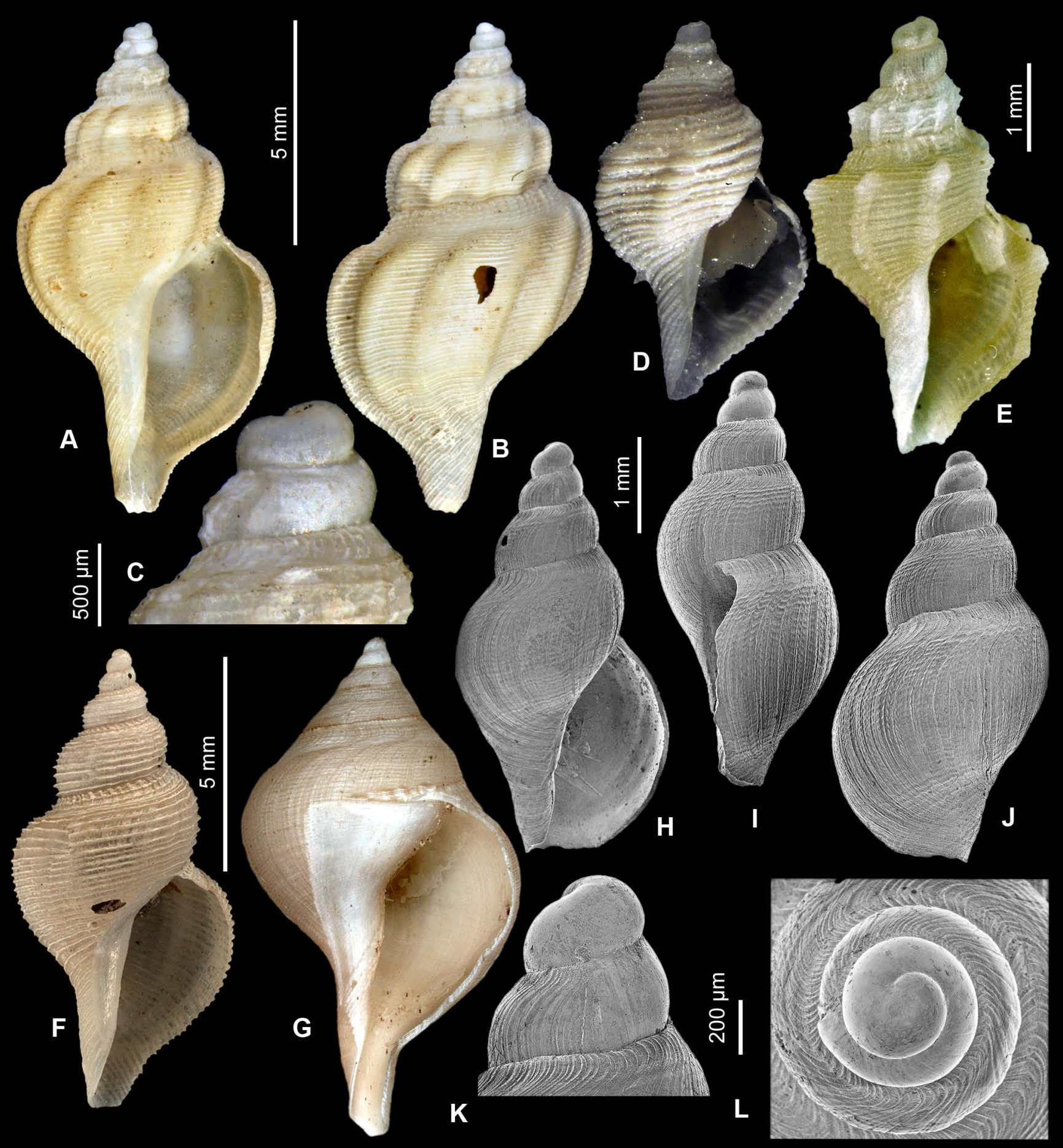




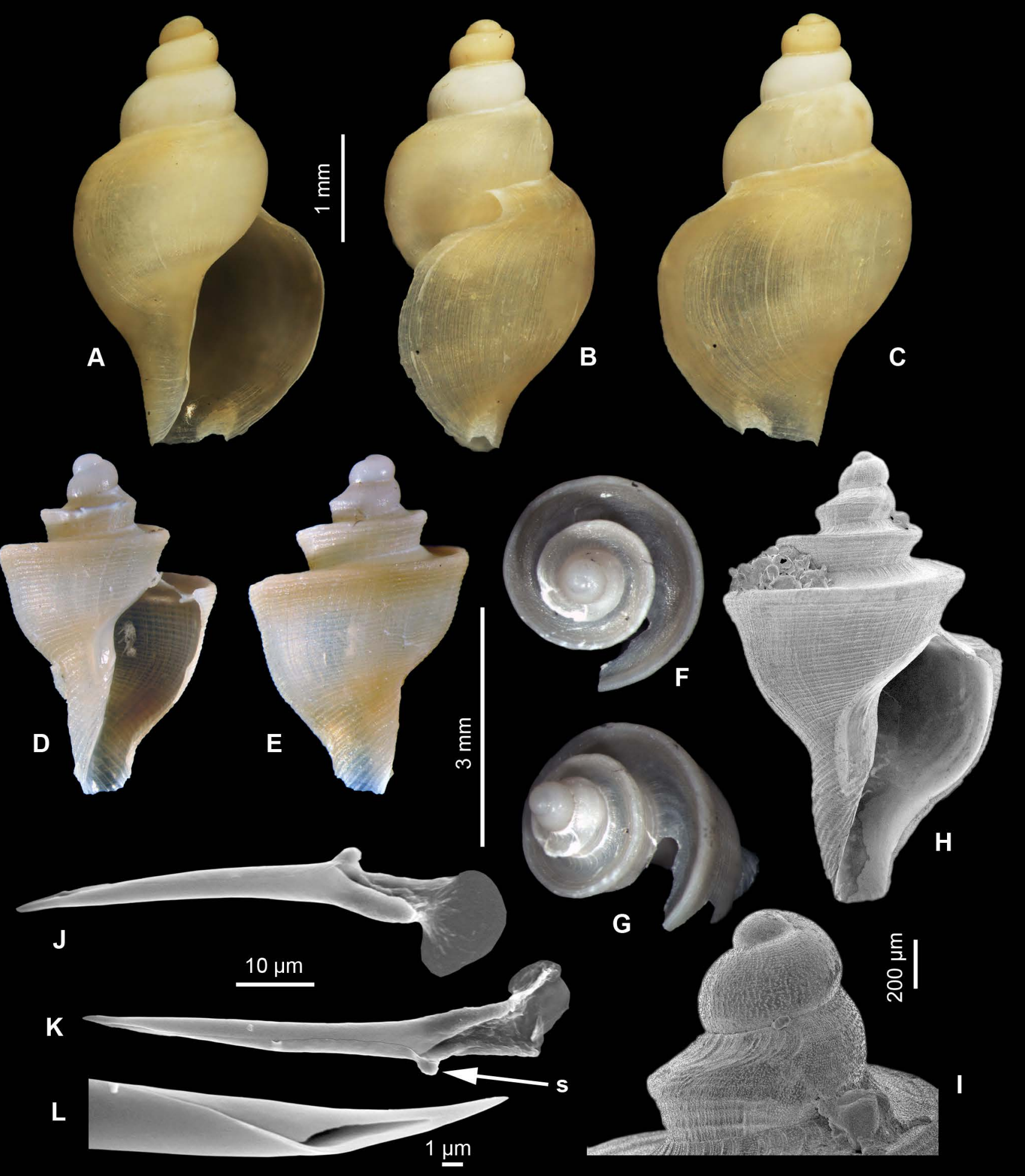




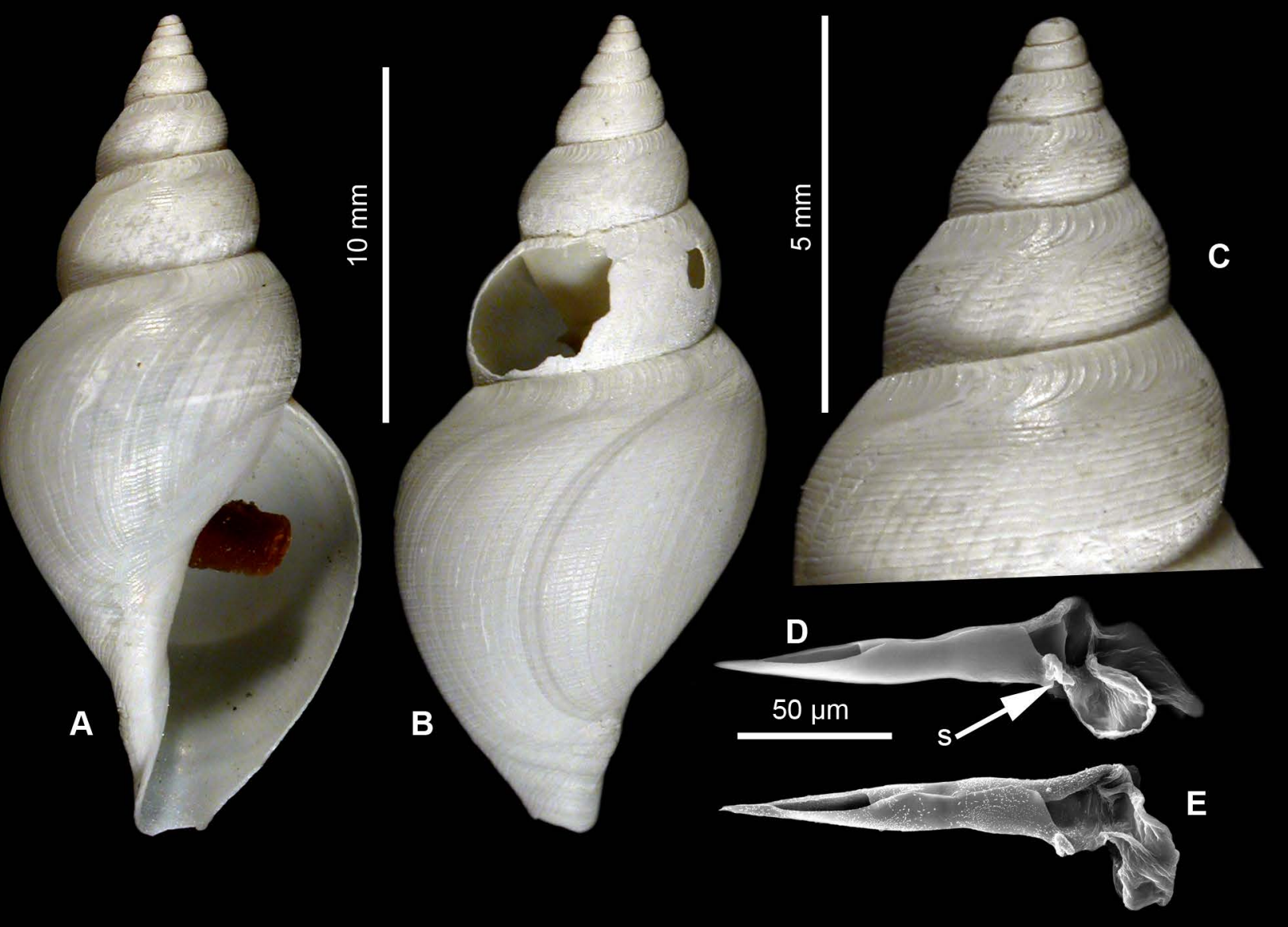


Cochlespira sp. IM-2007-40568

1

Aforia serranoi holotype

$0.47 \quad$ Aforia magnifica

${ }_{1}$ USNM 1121900

Aforia magnifica FM9991601 0.99

USNM 1121894 


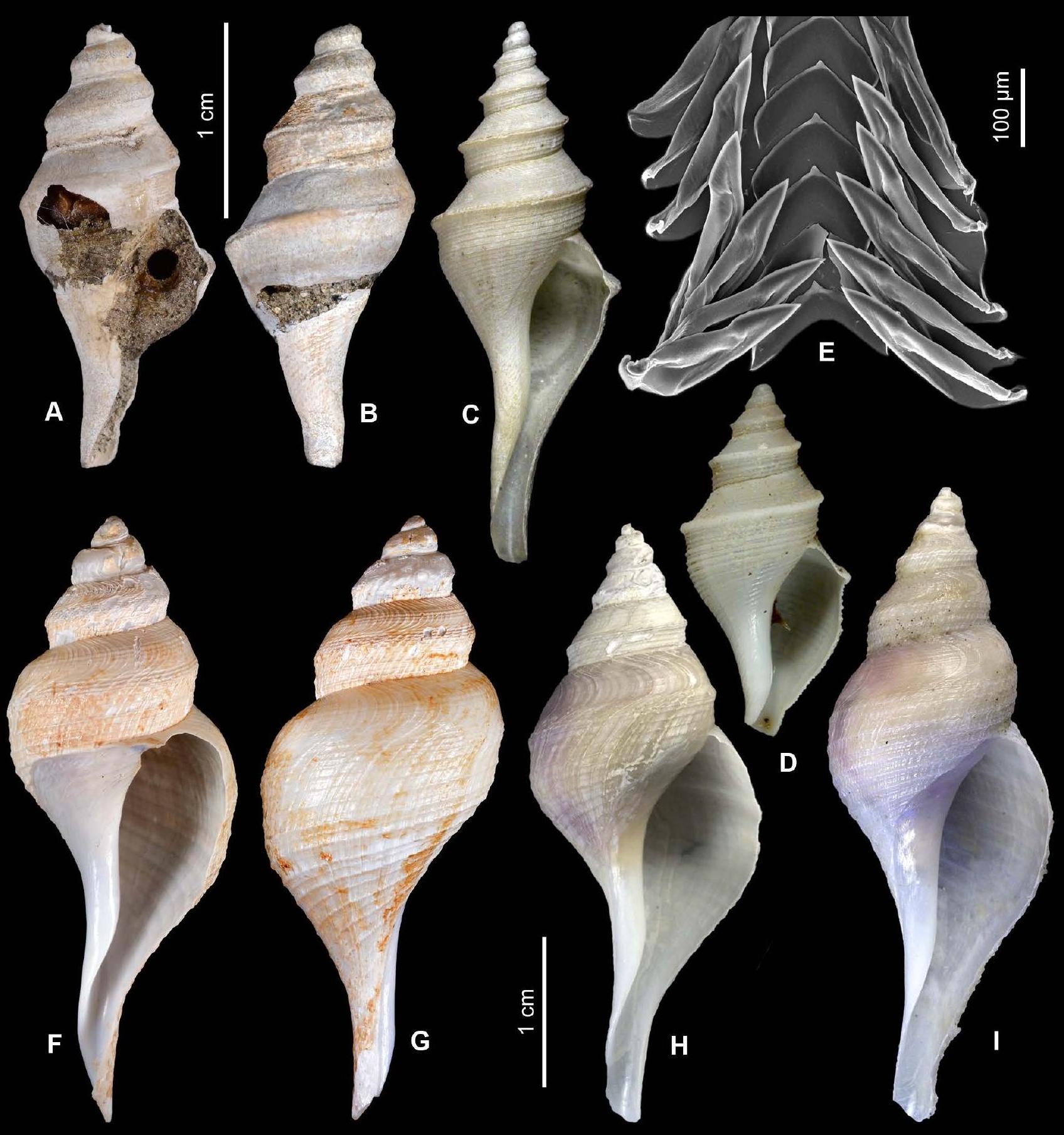




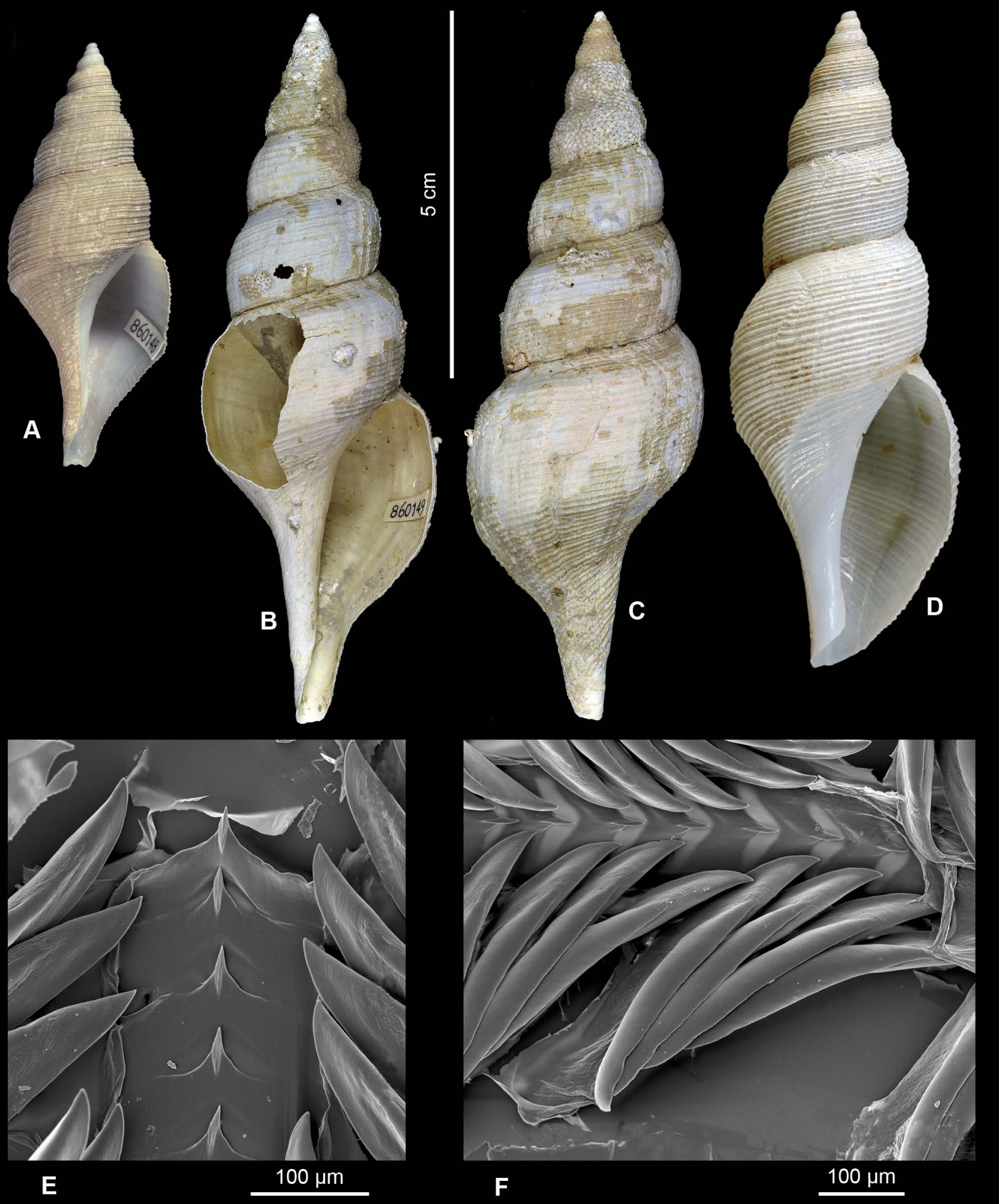




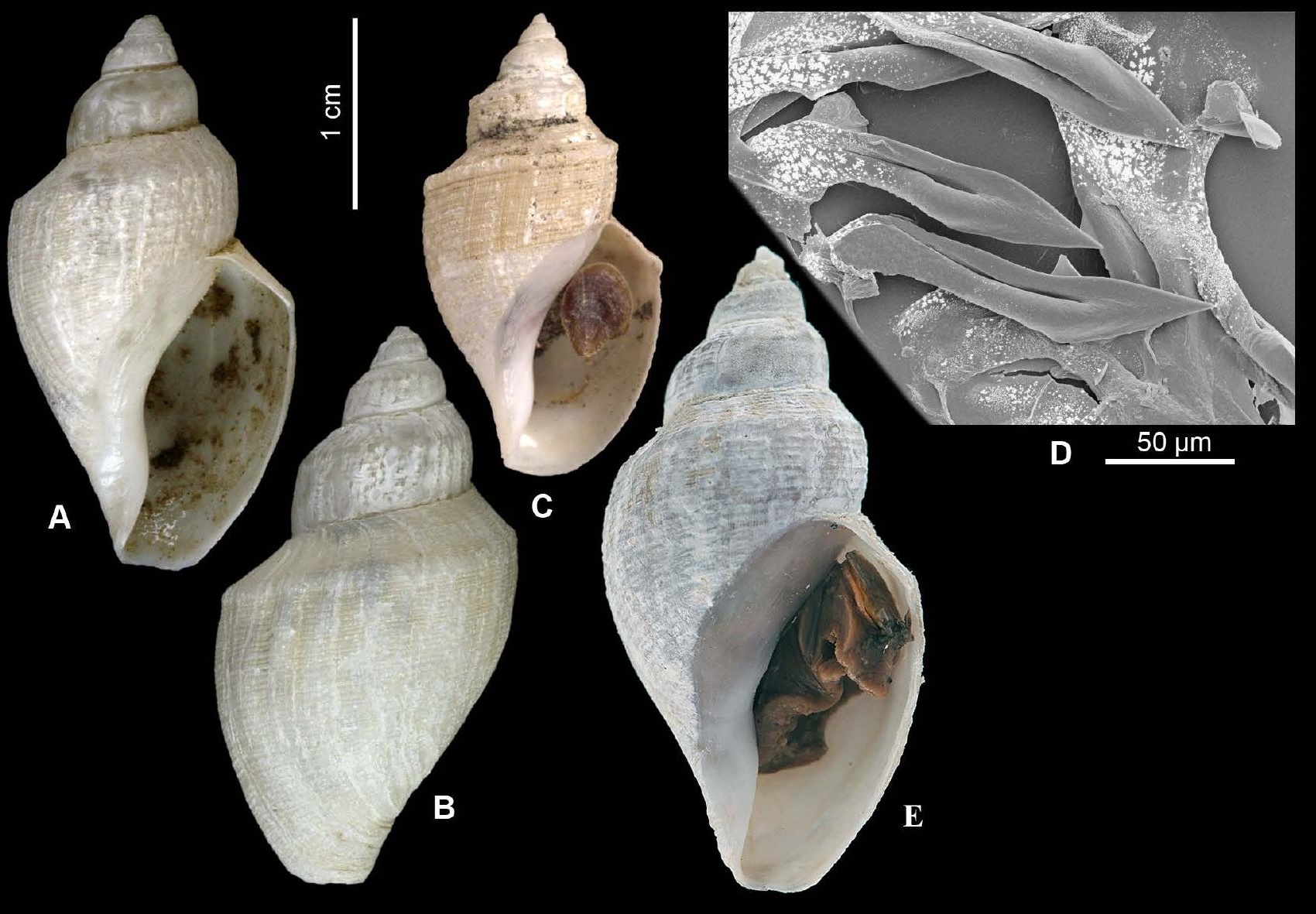




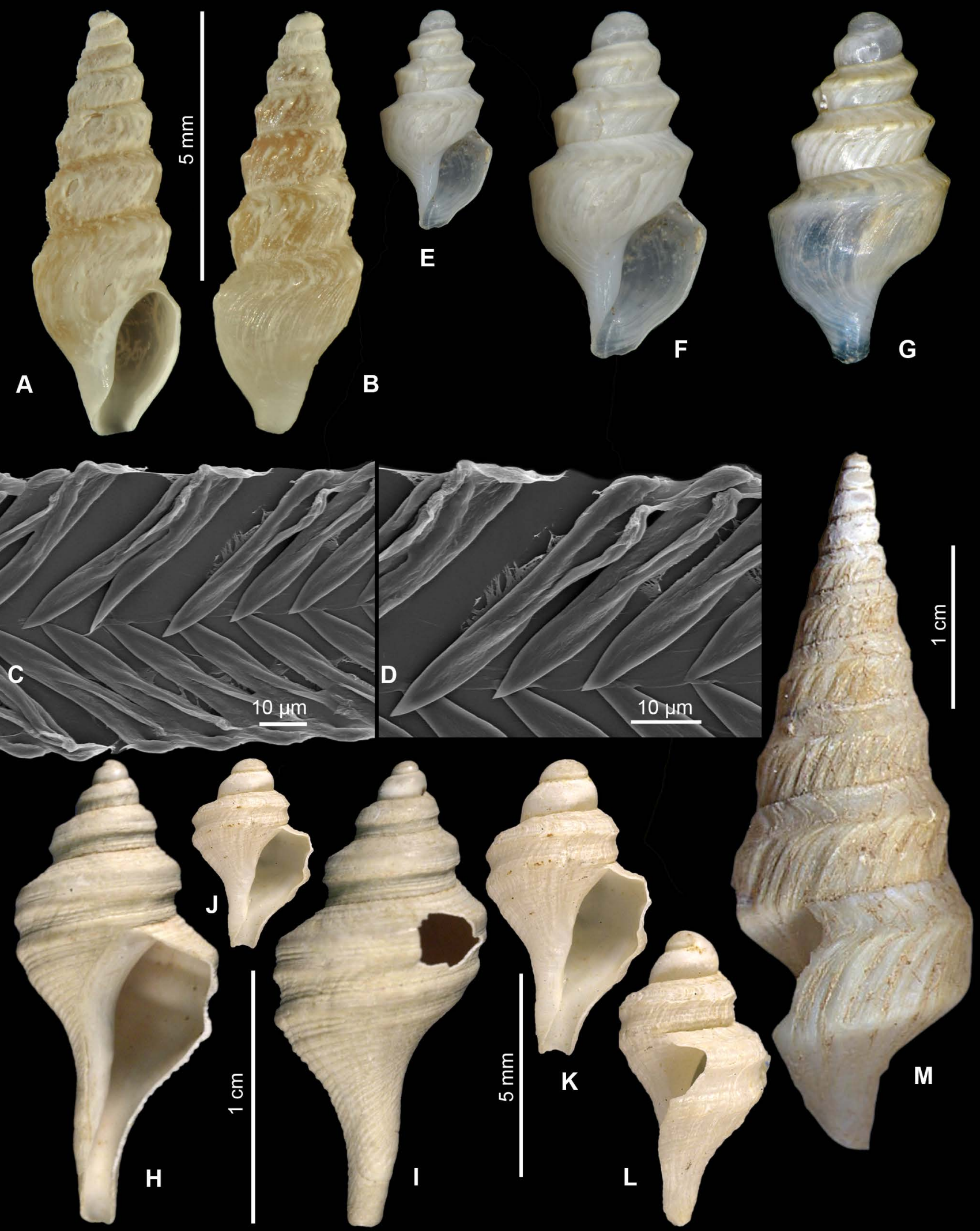




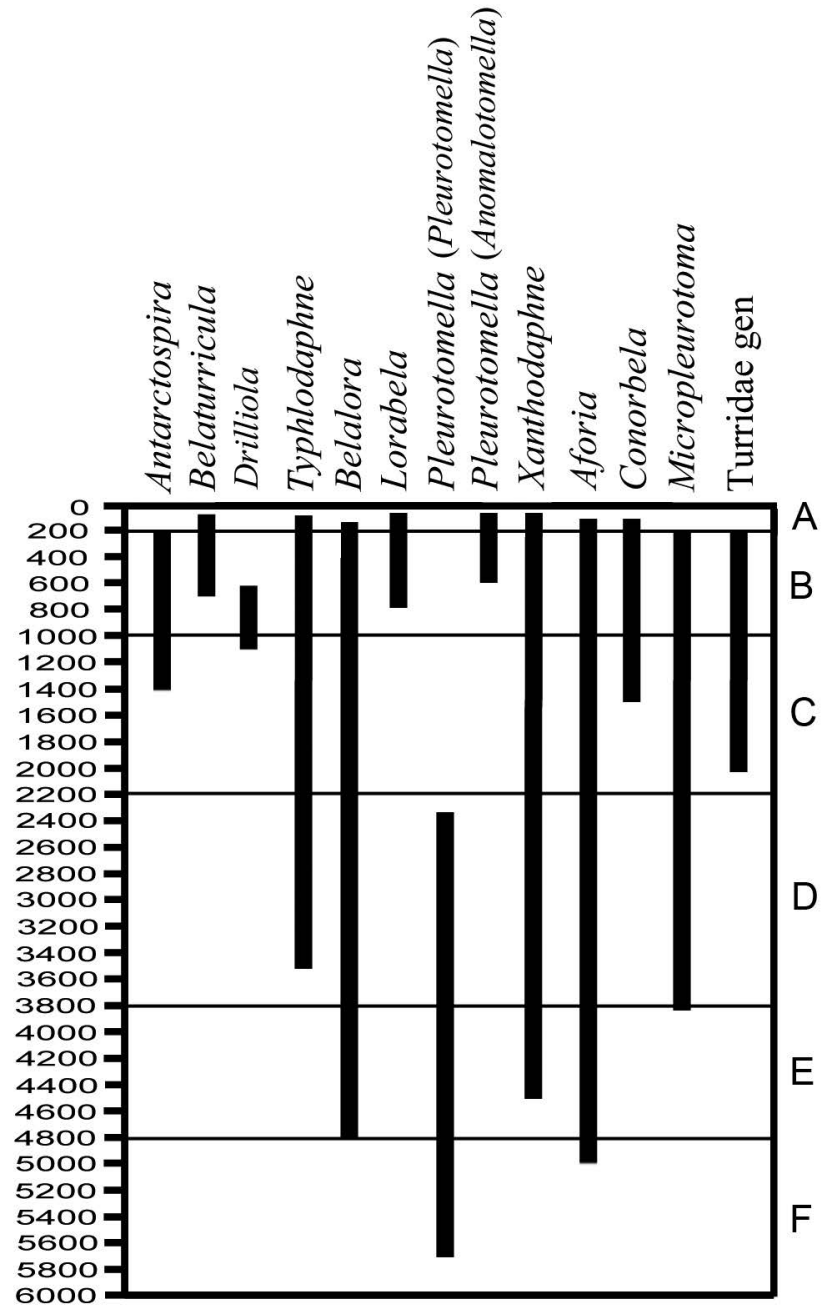




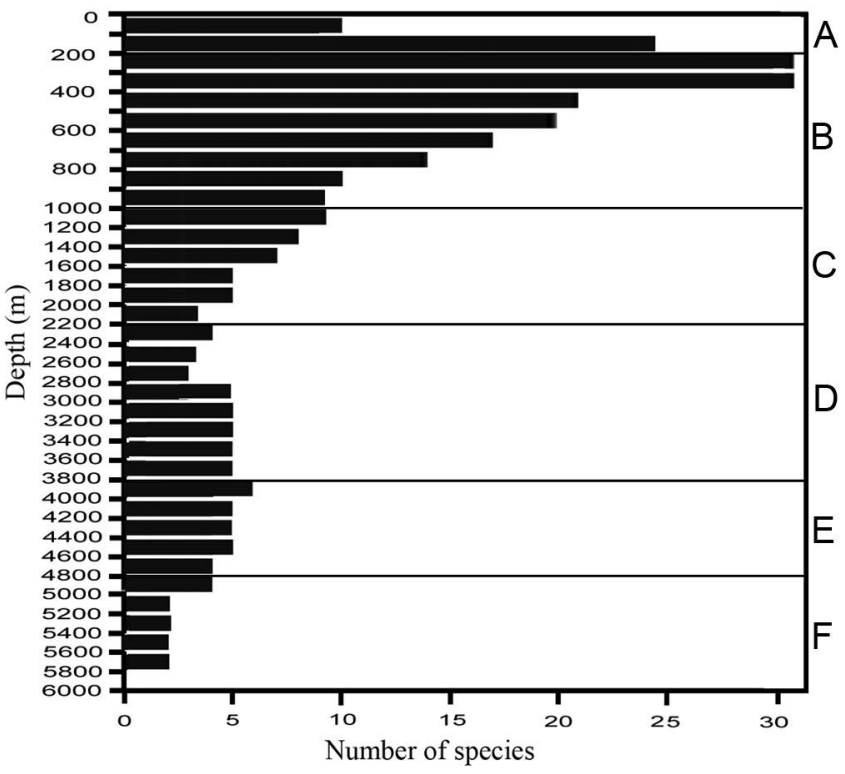

